This document was prepared in conjunction with work accomplished under Contract No. DE-AC09-96SR18500 with the U. S. Department of Energy.

\title{
DISCLAIMER
}

This report was prepared as an account of work sponsored by an agency of the United States Government. Neither the United States Government nor any agency thereof, nor any of their employees, nor any of their contractors, subcontractors or their employees, makes any warranty, express or implied, or assumes any legal liability or responsibility for the accuracy, completeness, or any third party's use or the results of such use of any information, apparatus, product, or process disclosed, or represents that its use would not infringe privately owned rights. Reference herein to any specific commercial product, process, or service by trade name, trademark, manufacturer, or otherwise, does not necessarily constitute or imply its endorsement, recommendation, or favoring by the United States Government or any agency thereof or its contractors or subcontractors. The views and opinions of authors expressed herein do not necessarily state or reflect those of the United States Government or any agency thereof. 


\section{SCOPING STUDIES TO DEVELOP A METHOD TO DETERMINE PARTICLE SIZE IN SIMULANT SLUDGE SLURRIES BY SIEVING}

D. R. Click

February 7, 2005

Analytical Development Section

Savannah River National Laboratory

Aiken, SC 29808

Prepared for the U.S. Department of Energy Under Contract Number DEAC09-96SR18500

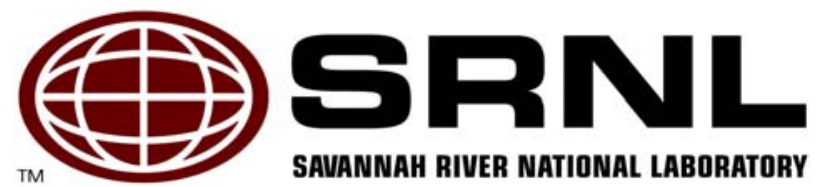


Key Words: method

development, sieving, particle size

\section{SCOPING STUDIES TO DEVELOP A METHOD TO DETERMINE PARTICLE SIZE IN SIMULANT SLUDGE SLURRIES BY SIEVING}

D. R. Click

February 7, 2005

Analytical Development Section

Savannah River National Laboratory

Aiken, SC 29808

Prepared for the U.S. Department of Energy Under Contract Number DEAC09-96SR18500

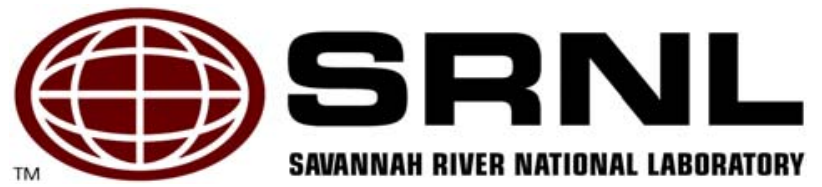


This page was intentionally left blank 


\section{EXECUTIVE SUMMARY}

A physical separation method (i.e. sieving) was investigated to determine particle size distribution in non-radioactive sludge slurry simulants with the goal of implementation into the SRNL (Savannah River National Laboratory) shielded cells for use with radioactive sludge slurries. The investigation included obtaining the necessary experimental equipment, developing accessory equipment for use with the sieve shaker (to be able to sieve simulant slurries with aqueous solutions), sieving three different simulant slurries through a number of sieves and determining the particle size distribution gravimetrically, and developing a sufficient cleaning protocol of the sieves for re-use.

The experimental protocol involved successive sieving of a NIST standard (to check the particle size retention of the sieves) and three non-radioactive slurry simulants (Batch 3 Tank 40 Test 3, Tank 40 Drum 3 and CETL Sludge Batch 2, which had been previously characterized by Microtrac analysis) through smaller and smaller sieves (150 microns $\rightarrow 5$ microns) via use of the 'wet' sieving system or by hand. For each of the three slurries, duplicate experiments were carried out using filtered supernate and DI water (to check the accuracy of the method versus Microtrac data) to sieve the slurry.

Particle size determinations using the wet sieving system with DI water agree well with Microtrac data on a volume basis and in some cases the sieving data may be more accurate particularly if the material sieved had large particles. A correction factor had to be applied to data obtained from experiments done with supernate due to the dissolved solids which dried upon the sieves in the drying stage of the experiments. Upon subtraction of the correction factors, the experimental results were very similar to those obtained with DI water. It should be noted that approximately $250 \mathrm{~mL}$ of each of three simulant slurries was necessary to have enough filtered supernate available to carry out the experiments. The experimental results for the slurries are below with Microtrac data.

- $\quad$ Batch 3 Tank 40 Test 3

o $\sim 85 \%$ of the particles are less than 6 microns via Microtrac

o $\sim 78 \%$ of the particles are less than 6 microns via sieving with supernate

o $\sim 68 \%$ of the particles are less than 6 microns via sieving with water

- $\quad$ Tank 40 Drum 3

o $\sim 71 \%$ of the particles are less than 6 microns via Microtrac

o $\sim 91 \%$ of the particles are less than 6 microns via sieving with supernate

o $\sim 85 \%$ of the particles are less than 6 microns via sieving with water

- $\quad$ CETL Sludge Batch 2

o $\sim 30 \%$ of the particles are less than 6 microns via Microtrac

o $\sim 30 \%$ of the particles are less than 6 microns via sieving with supernate

o $\sim 30 \%$ of the particles are less than 6 microns via sieving with water

The design of the experimental equipment was sufficient initially, but some pieces of the equipment began failing over time due to the caustic nature of the supernate and the vibrations from the sieve shaker. It is therefore recommended that upgrades to the experimental equipment be done before implementation into the SRNL shielded cells. Theses upgrades include using manipulator friendly connections, changing brass parts for stainless steel parts, using Teflon rather than polycarbonate, and possibly a change of pumps used to re-circulate the sieving fluid. 
Revision 0

\section{TABLE OF CONTENTS}

EXECUTIVE SUMMARY

iii

LIST OF FIGURES

LIST OF TABLES

LIST OF ACRONYMS

1.0 INTRODUCTION AND BACKGROUND

2.0 EXPERIMENTAL

3.0 RESULTS

4.0 CONCLUSIONS

$\mathrm{V}$

5.0 RECOMMENDATIONS/PATH FORWARD

6.0 REFERENCES

7.0 ACKNOWLEDGEMENTS

APPENDIX A-D

$\mathrm{V}$

vi

1

3

11

21

23

25

27

29-61 


\section{LIST OF FIGURES}

Figure 2.1 Experimental apparatus developed by ADS for sieving wet simulant slurry......... 3 Figure 2.2 A is representative of a plain weave mesh used with sieves 20 microns and larger and results in square openings in the mesh. B is an example of the twill Dutch weave which results in wedged shaped or elliptical type openings in the mesh.......................... 4

Figure 3.1 SEM analysis of particles collected on 25 micron sieve. $90 \%$ of the particles are above 25 microns. Fifty randomly chosen particles were measured and graphed.......... 12

Figure 3.2 SEM of particles collected on 20 micron sieve screen......................................... 12

Figure 3.3 Dried sieves used in experiment 1.3. From top left to right, 25 micron sieve, 20 micron sieve, 12-14 micron sieve (200x1400 mesh), 11-12 micron sieve (250x1400 mesh) and an 8-9 micron sieve (325x2300 mesh), respectively................................. 13

Figure 3.4 Experimental results obtained from sieving NIST1984 standard.......................... 13

Figure 3.5 Batch 3 Tank 40 Test 3 simulant slurry sieving results using water as recirculating fluid or as the rinsing solution if done by hand (\% Mass Below Sieve Size vs Sieve Size (microns)).

Figure 3.6 Sieves used in experiment 3.2. From top left to right 38 micron sieve, 32 micron sieve, 25 micron sieve, 20 micron sieve, 16-18 micron sieve (165x1400 mesh), 12-14 micron sieve (200x1400 mesh), 11-12 micron sieve (250x1400 mesh), 8-9 micron sieve (325x2300 mesh), and a 5-6 micron sieve (510x3600 mesh), respectively..... 15

Figure 3.7 Batch 3 Tank 40 Test 3 simulant slurry sieving results using supernate as recirculating fluid (\% Mass Below Sieve Size vs Sieve Size (microns)). Experiment 3.4 is the corrected and averaged data based upon soluble solids in the supernate.

Figure 3.8 Tank 40 Drum 3 simulant sieving results using water as re-circulating fluid (\% Mass Below Sieve Size vs Sieve Size (microns))...................................................... 16

Figure 3.9 Tank 40 Test 3 simulant sieving results using supernate as re-circulating fluid (\% Mass Below Sieve Size vs Sieve Size (microns)). Experiment 5.3 is the corrected and averaged data based upon soluble solids in the supernate.

Figure 3.10 CETL Sludge Batch 2 simulant sieving results using water as re-circulating fluid (\% Mass Below Sieve Size vs Sieve Size (microns)). ................................................. 18

Figure 3.11 CETL Sludge Batch 2 simulant sieving results using supernate as re-circulating fluid (\% Mass Below Sieve Size vs Sieve Size (microns)). 19

\section{LIST OF TABLES}

Table 2.1 Elemental composition of Batch 3 Tank 40 Test 3, Tank 40 Drum 3 and CETL SB-

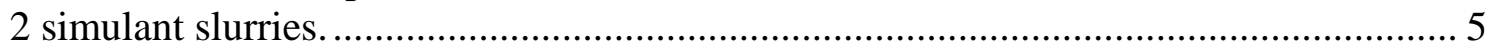




\section{LIST OF ACRONYMS}

DWPF

SB

SRNL

HDPE

SEM

DI

NIST
Defense Waste Processing Facility

Sludge Batch

Savannah River National Laboratory

High Density Polyethylene

Scanning Electron Microscopy

De-Ionized

National Institute of Standards and Technology 


\subsection{INTRODUCTION AND BACKGROUND}

For each sludge batch that is processed in DWPF (Defense Waste Processing Facility), SRNL (Savannah River National Laboratory) performs a characterization of the sludge slurry. The sludge slurry is analyzed for chemical composition, radionuclide composition and physical characteristics (weight percent solids, rheology). The information obtained from this characterization is used in radioactive demonstrations of the DWPF process (after is has been done on non-radioactive sludge simulants) to evaluate potential processing issues and to identify a DWPF processing strategy.

As stated above, there are several characteristics that can influence the processing of a sludge batch, and one of these is the rheology of the sludge slurry. Rheology measurements are performed to ensure that the slurry can be transferred and mixed properly. The flow curves (shear rate vs. shear stress) generated from the rheology measurements are modeled to obtain the yield stresses and consistencies of these samples. The yield stresses and the consistencies are then compared to the design bases for the DWPF to determine if the feed may pose potential processing problems (i.e. pumping/ transfer problems).

To help SRNL/DWPF understand the rheology (yield stress and consistency of a sludge slurry sample) of a given sludge batch the parameters that influence the rheology must be measured on both nonradioactive and radioactive sludge slurry samples $(\mathrm{pH}$, temperature, chemical composition, particle size, etc.). Particle size has been shown to affect rheological behavior in studies using non-radioactive sludge slurry. ${ }^{1}$

Currently, there is an abundance of particle size data (via Microtrac) for the non-radioactive sludge slurries, but very little particle size information is available for radioactive sludge slurries. The information that is available for the radioactive sludge slurry has been obtained using a Microtrac instrument. During Microtrac analysis a laser beam is projected through a transparent sample cell that contains a stream of moving particles suspended in a fluid. Light rays that strike particles are scattered through angles inversely proportional to particle size. The photodetector arrays measure the quantity of light (flux) at predetermined angles. Electrical signals proportional to the measured light flux values are then processed by the computer to form a multichannel histogram of the particle size distribution.

The Microtrac data obtained thus far on radioactive sludge slurries is potentially suspect, due to the large dilution required to remove the radioactive sludge slurry samples from the Shielded Cells. It is thought that this large dilution may alter the true particle size of the sludge slurry. Although Microtrac analysis may still be pursued, the need to find an alternative means to determine particle size remains. Successive sieving of fine solid samples or liquid samples containing solids through smaller and smaller sieves to separate the particles by size and obtain a distribution is a viable mechanical method. To date, there has been one sieving experiment performed on radioactive sludge slurry to determine the particle size. ${ }^{2}$ The experiment was somewhat successful, but the majority of particles ( 60\%) were smaller than 20 microns. This document will describe scoping tests performed in order to develop a sieving method for determining particle size and distribution in non-radioactive sludge simulant for eventual application to radiological samples. 
WSRC-TR-2005-00077

Revision 0

This page intentionally left blank. 


\subsection{EXPERIMENTAL}

\section{Apparatus}

The Analytical Development Section of SRNL developed a wet sieving system to sieve simulant slurry. The experimental equipment is shown in Figure 2.1.

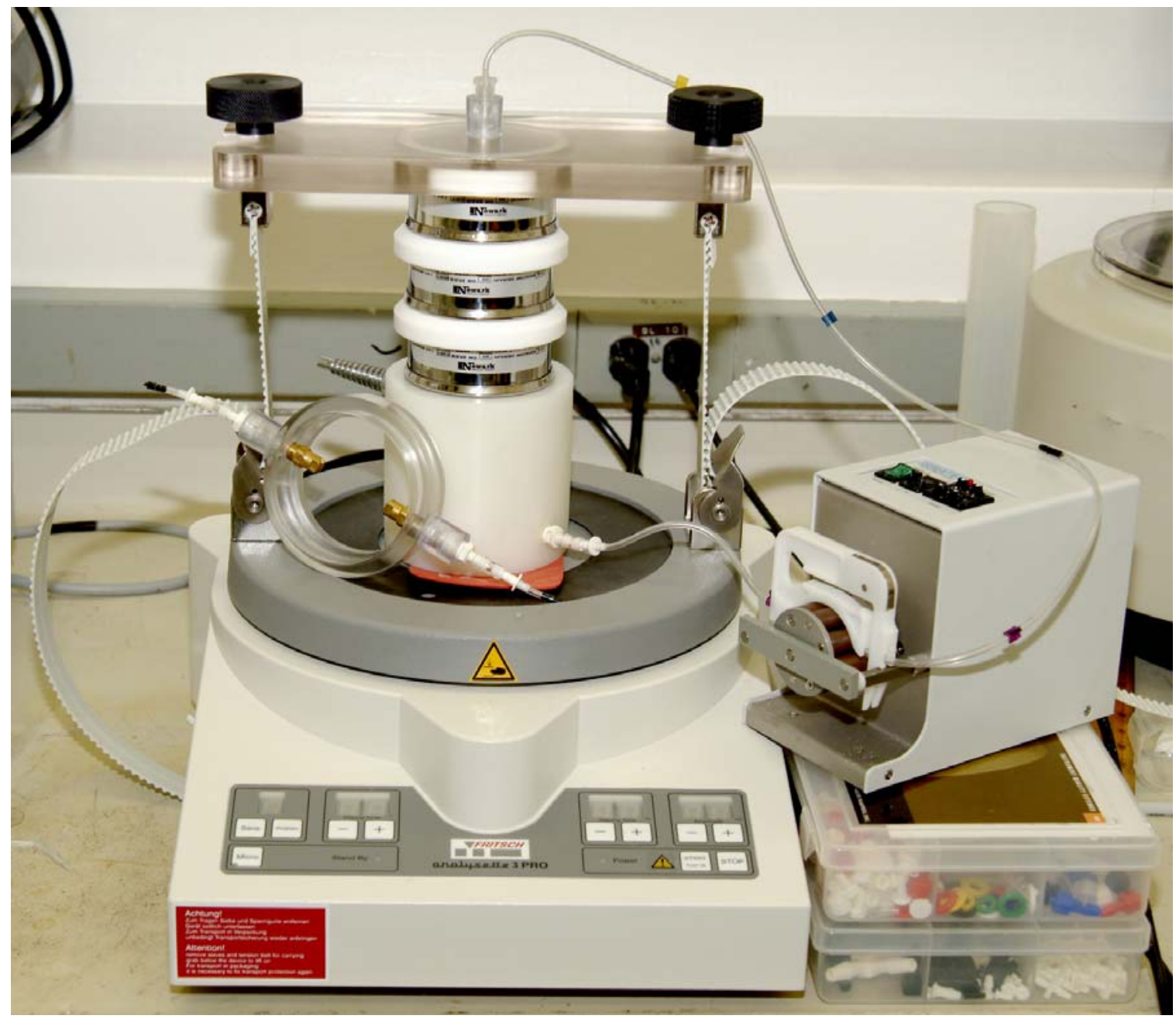

Figure 2.1 Experimental apparatus developed by ADS for sieving wet simulant slurry.

The system works by re-circulating slurry supernate or water, which has passed through the sieves and collected in the high density polyethylene (HDPE) sieve holder, back up to the top sieve by the use of a peristaltic pump while the sieves are being shaken by a sieve shaker. The HDPE sieve holder has a 150 $\mathrm{mL}$ reservoir and a hole for the use of vacuum (back left of holder). The vacuum hole is protected by a funnel inside the sieve holder so that the sieved liquid drains into the reservoir and does not get sucked up into the vacuum. There is also a small hole in the side near the bottom of the sieve holder which serves as a drain (front right of holder) so that supernate/water can be pumped out and re-circulated. The spacer ring (left of sieve holder) has two brass nozzles opposite $180^{\circ}$ which helps to spread out the supernate/water that is re-circulating into the sieves to aid in the sieving process. The vibratory sieve 
shaker is an Analysette 3 model manufactured by Fritsch. The shaker can be operated in two modes; normal and micro mode. The micro mode is used for sieves 20 microns and smaller. The sieves used during these experiments were made by Newark Wire Cloth Company and conform to ASTM

specification E-11. The plain weave mesh of the sieves size 20 microns and greater result in square shape openings and below 20 microns the twill Dutch weave of the mesh results in openings which are probably more wedged or elliptical in shape. The wedged shape openings of mesh less than 20 microns makes it more difficult for particles to pass through. It is for this reason that the sieve holder was developed with a vacuum attachment. The difference in the weave of the wires that make up the mesh of the two sieves is shown pictorially in Figure 2.2.

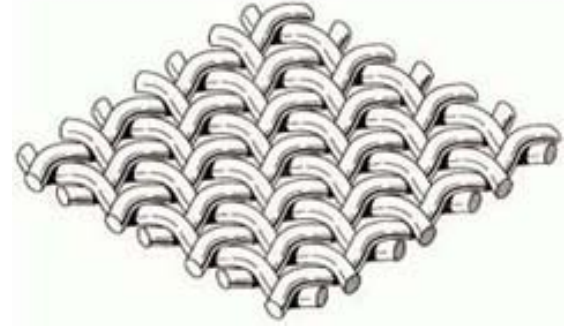

A

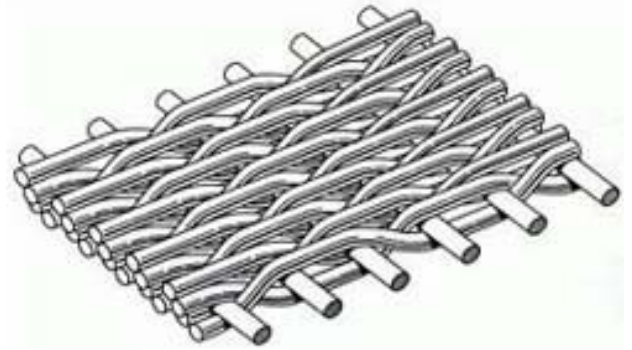

B

Figure 2.2 $\mathrm{A}$ is representative of a plain weave mesh used with sieves 20 microns and larger and results in square openings in the mesh. B is an example of the twill Dutch weave which results in wedged shaped or elliptical type openings in the mesh.

\section{Material}

The simulant sludge slurries given to ADS to perform sieving on were labeled Batch 3 Tank 40 Test 3, Tank 40 Drum 3 and CETL Sludge Batch 2. The insoluble solids content of the simulant slurries were measured and found to be $11.75 \%, 14.32 \%$ and $18.05 \%$, respectively. The elemental composition of the simulant slurries are shown below in Table 2.1. The NIST 1984 Microtrac standard was provided by Wilson Smith (ADS) and is a mixture of tungsten carbide and cobalt, ranging in particle size 9.5 to 26.5 microns. 
WSRC-TR-2005-00077

Revision 0

Table 2.1 Elemental composition of Batch 3 Tank 40 Test 3, Tank 40 Drum 3 and CETL SB-2 simulant slurries.

\begin{tabular}{|c|c|c|c|c|c|}
\hline \multicolumn{2}{|c|}{$\begin{array}{c}\text { Batch } 3 \text { Tank } 40 \text { Test } 3 \\
\text { Simulant }\end{array}$} & \multicolumn{2}{|c|}{ Tank 40 Drum 3 Simulant } & \multicolumn{2}{|c|}{$\begin{array}{c}\text { CETL Sludge Batch } 2 \\
\text { Simulant }\end{array}$} \\
\hline Element & $\begin{array}{c}\text { Concentration } \\
\text { ( } \mu \mathrm{g} / \mathrm{g} \text { of } \\
\text { slurry })\end{array}$ & Element & $\begin{array}{c}\text { Concentration } \\
\text { ( } \mu \mathrm{g} / \mathrm{g} \text { of } \\
\text { slurry) }\end{array}$ & Element & $\begin{array}{c}\text { Concentration } \\
\text { ( } \mu \mathrm{g} / \mathrm{g} \text { of } \\
\text { slurry) }\end{array}$ \\
\hline $\mathrm{Ag}$ & 43.6 & $\mathrm{Al}$ & 12400 & $\mathrm{Al}$ & 15200 \\
\hline $\mathrm{Al}$ & 12970 & $\mathrm{Ba}$ & 240 & $\mathrm{Ba}$ & $<15.0$ \\
\hline $\mathrm{Ba}$ & 88.5 & $\mathrm{Ca}$ & 4850 & $\mathrm{Ca}$ & 5400 \\
\hline $\mathrm{Ca}$ & 3220 & $\mathrm{Cr}$ & 380 & $\mathrm{Cu}$ & 280 \\
\hline $\mathrm{Cd}$ & 160 & $\mathrm{Cu}$ & 240 & $\mathrm{Fe}$ & 56900 \\
\hline $\mathrm{Ce}$ & 180 & $\mathrm{Fe}$ & 47400 & $\mathrm{~K}$ & 120 \\
\hline $\mathrm{Cr}$ & 300 & $\mathrm{~K}$ & 34.4 & $\mathrm{Mg}$ & 190 \\
\hline $\mathrm{Cu}$ & 52 & $\mathrm{Mg}$ & 270 & $\mathrm{Mn}$ & 7900 \\
\hline $\mathrm{Fe}$ & 34560 & $\mathrm{Mn}$ & 4280 & $\mathrm{Na}$ & 5900 \\
\hline $\mathrm{Gd}$ & 91.3 & $\mathrm{Na}$ & 8610 & $\mathrm{Ni}$ & 1940 \\
\hline $\mathrm{K}$ & 370 & $\mathrm{Ni}$ & 530 & $\mathrm{Si}$ & 1850 \\
\hline $\mathrm{La}$ & 71.7 & $\mathrm{~Pb}$ & 390 & $\mathrm{Zn}$ & 530 \\
\hline $\mathrm{Li}$ & 200 & $\mathrm{Si}$ & 1900 & $\mathrm{Zr}$ & 1000 \\
\hline $\mathrm{Mg}$ & 2980 & $\mathrm{Ti}$ & $<13.0$ & & \\
\hline $\mathrm{Mn}$ & 7330 & $\mathrm{Zn}$ & 430 & & \\
\hline $\mathrm{Na}$ & 26550 & $\mathrm{Zr}$ & 880 & & \\
\hline $\mathrm{Ni}$ & 1970 & $\mathrm{Ru}$ & $<130$ & & \\
\hline$P$ & 730 & & & & \\
\hline $\mathrm{Pb}$ & 8.43 & & & & \\
\hline $\mathrm{S}$ & 280 & & & & \\
\hline $\mathrm{Sb}$ & 190 & & & & \\
\hline Si & 790 & & & & \\
\hline Sn & $<280$ & & & & \\
\hline $\mathrm{Sr}$ & 710 & & & & \\
\hline $\mathrm{Ti}$ & 42.2 & & & & \\
\hline $\mathrm{Zn}$ & 71.7 & & & & \\
\hline $\mathrm{Zr}$ & 9.84 & & & & \\
\hline
\end{tabular}

\section{Sieving Procedures}

\section{$\underline{\text { NIST } 1984 \text { Standard }}$}

\section{Experiment 1.1}

The NIST 1984 standard was mixed by rotating and turning the bottle end-over-end twenty times and a $1.0442 \mathrm{~g}$ portion was weighed into a beaker. The contents of the beaker were transferred into a 20 micron sieve which was the top sieve of a stack consisting of a pre-weighed 20 micron sieve, 16-18 micron sieve (165x1400 mesh), 12-14 micron sieve (200x1400 mesh) and an 8-9 micron sieve (325x2300 mesh), respectively. The vibratory sieve shaker was put in micro mode, set at an interval time of 10 seconds and a total sieve time of 45 minutes. No water or vacuum was used. Each sieve was re-weighed after the sieving time had ended. 


\section{Experiment 1.2}

The NIST 1984 standard was mixed by rotating and turning the bottle end-over-end twenty times and a $1.0760 \mathrm{~g}$ portion was weighed into a beaker. The contents of the beaker were transferred into a 20 micron sieve which was the top sieve of a stack consisting of a pre-weighed and pre-wetted 20 micron sieve, 1618 micron sieve (165x1400 mesh), 12-14 micron sieve (200x1400 mesh) and an 8-9 micron sieve (325x2300 mesh), respectively. The vibratory sieve shaker was put in micro mode, set at an interval time of 10 seconds and a total sieve time of 45 minutes. Water was re-circulated over the sieves for this experiment and vacuum was used periodically. Each sieve was dried overnight at $50{ }^{\circ} \mathrm{C}$ and re-weighed. $50{ }^{\circ} \mathrm{C}$ was the maximum drying temperature recommended by the manufacturer. Experiment 1.3

The NIST 1984 standard was mixed by rotating and turning the bottle end-over-end twenty times and a $1.0286 \mathrm{~g}$ portion was weighed into a beaker. The contents of the beaker were transferred into a 25 micron sieve which was the top sieve of a stack consisting of a pre-weighed and pre-wetted 25 micron sieve, 20 micron sieve, 12-14 micron sieve (200x1400 mesh), 11-12 micron sieve (250x1400 mesh) and an 8-9 micron sieve (325x2300 mesh), respectively. The vibratory sieve shaker was put in micro mode, set at an interval time of 10 seconds and a total sieve time of $10 \mathrm{~min}$. At the end of 10 minutes, the top sieve was rinsed and removed from the stack. The sieve system was re-assembled and sieving was commenced for an additional 10 minutes. This pattern was repeated down to the last sieve. Water was re-circulated over the sieves for this experiment and vacuum was used periodically. Each sieve was dried overnight at $50{ }^{\circ} \mathrm{C}$ and re-weighed. Solids collected were submitted for Microtrac/SEM analysis.

\section{Experiment 1.4}

The NIST 1984 standard was mixed by rotating and turning the bottle end-over-end twenty times and a $1.1460 \mathrm{~g}$ portion was weighed into a beaker. The contents of the beaker were transferred into a preweighed 25 micron sieve. The sieve was shaken by hand and rinsed with $\sim 50 \mathrm{~mL}$ of DI water. The particles that went through were collected in the beaker and then poured onto the next sieve, a preweighed 20 micron sieve. This pattern was continued through a pre-weighed 16-18 micron sieve (165x1400 mesh), 12-14 micron sieve (200x1400 mesh), 11-12 micron sieve (250x1400 mesh) and an 8-9 micron sieve (325x2300 mesh), respectively. The last two sieves were set in the HDPE holder and required the use of vacuum to get the water to pass through the sieves but they were still hand shaken. Each sieve was dried overnight at $50{ }^{\circ} \mathrm{C}$ and re-weighed. Solids collected were submitted for Microtrac/SEM analysis.

\section{Batch 3 Tank 40 Test 3}

\section{Experiment 2.1}

$5.1150 \mathrm{~g}$ of simulant slurry was added to a weighing cup, diluted in $50 \mathrm{~mL}$ of water and poured into a preweighed pre-wetted 38 micron sieve which was the top sieve of a stack consisting of the pre-weighed and pre-wetted (with DI water) 38 micron sieve, a 32 micron sieve and a 25 micron sieve. The vibratory sieve shaker was put in micro mode, set at an interval time of 10 secs and a total sieve time of 10 min while water was re-circulating. The top sieve was then rinsed and removed. The wet sieving system was reassembled and the sieves where shaken for an additional 10 mins. This pattern was repeated down to the last sieve in the three sieve stack. The particles in the slurry which collected in the HDPE reservoir were then sieved through another stack of pre-weighed and pre-wetted sieves which began with a 20 micron sieve, then a 16-18 micron sieve (165x1400 mesh), and then a 12-14 micron sieve (200x1400 mesh), 
respectively. The process was continued through the last three sieves, an 11-12 micron sieve (250x1400 mesh), an 8-9 micron sieve (325x2300 mesh), and ending with a 5-6 micron sieve (510x3600 mesh), respectively. Water was re-circulated over the sieves for this experiment and vacuum was used periodically. Each sieve was dried overnight at $50{ }^{\circ} \mathrm{C}$ and re-weighed.

\section{Experiment 2.2}

$5.0528 \mathrm{~g}$ of slurry simulant was added to a weighing cup, diluted in $50 \mathrm{~mL}$ of water and then poured into a pre-weighed pre-wetted 38 micron sieve which was the top sieve of a stack consisting of the preweighed and pre-wetted 38 micron sieve, a 32 micron sieve and a 25 micron sieve. The vibratory sieve shaker was put in the micro mode, set at an interval time of 10 secs and a total sieve time of 10 min while water was re-circulating. The top sieve was then rinsed and removed. The wet sieving system was reassembled and the sieves where shaken for an additional 10 mins. This pattern was repeated down to the last sieve in a three sieve stack. The particles in the slurry which collected in the HDPE reservoir were then poured into a clean sieve that was the size of the last sieve screen in the previous stack (25 microns) and then sieved through another stack of pre-weighed and pre-wetted sieves beginning with 20 micron sieve, a 16-18 micron sieve (165x1400 mesh), and a 12-14 micron sieve (200x1400 mesh), respectively. The sieves were shaken for 10 min while water was re-circulating and then the top sieve was rinsed and removed. The wet sieving system was re-assembled and the sieves where shaken for 10 mins again. This pattern was repeated down to the last sieve in a three sieve stack. A similar pattern was repeated for the last three sieves (11-12 micron sieve (250x1400 mesh), an 8-9 micron sieve (325x2300 mesh), a 5-6 micron sieve (510x3600 mesh)) except that $0.5983 \mathrm{~g}$ of simulant slurry was diluted in $50 \mathrm{~mL}$ of water. Each sieve was dried overnight at $50{ }^{\circ} \mathrm{C}$ and re-weighed.

\section{Experiment 2.3}

$5.2097 \mathrm{~g}$ of slurry simulant was added to a weighing cup, diluted in $30 \mathrm{~mL}$ of water and then poured into a pre-weighed, pre-wetted 38 micron sieve held over a beaker. The sieve was shaken by hand and rinsed. The particles that went through were collected in the beaker and then poured onto the next sieve, a preweighed, pre-wetted 32 micron sieve and then a 25 micron sieve. $1.147 \mathrm{~g}$ was used for the next three sieves which consisted of a 20 micron sieve, a 16-18 micron sieve (165x1400 mesh), and a 12-14 micron sieve (200x1400 mesh). $0.5312 \mathrm{~g}$ of slurry simulant were used for the last three sieves which consisted of an 11-12 micron sieve (250x1400 mesh), an 8-9 micron sieve (325x2300 mesh), and a 5-6 micron sieve (510x3600 mesh), respectively. The last three sieves were set in the HDPE holder and required use of vacuum to get the water to pass through the sieves but they were still hand shaken. Each sieve was dried overnight at $50{ }^{\circ} \mathrm{C}$ and re-weighed. Data obtained from experiments 2.1 -2.3 are contained in Table 1.

\section{Experiment 3.1}

$5.0433 \mathrm{~g}$ of slurry simulant was added to a weighing cup and diluted in $15 \mathrm{~mL}$ of previously filtered supernate (by use of a 0.43 micron filter) and then poured into a pre-weighed pre-wetted 38 micron sieve which was the top sieve of a stack consisting of the pre-weighed and pre-wetted 38 micron sieve, a 32 micron sieve and a 25 micron sieve. The vibratory sieve shaker was put in the micro mode, set at an interval time of 10 secs and a total sieve time of $10 \mathrm{~min}$. Supernate was re-circulated during the sieving. After 10 mins the top sieve was rinsed with $\sim 10 \mathrm{~mL}$ of fresh previously filtered supernate and then removed. The wet sieving system was re-assembled and the sieves where shaken for 10 mins again. This pattern was repeated down to the last sieve in a three sieve stack. The slurry solution which collected in the HDPE reservoir was mixed with an additional $20 \mathrm{~mL}$ of filtered supernate and then sieved through another stack of pre-weighed and pre-wetted sieves beginning with a 20 micron sieve, then a 16-18 micron sieve (165x1400 mesh), and then a 12-14 micron sieve (200x1400 mesh), respectively. The same 
process was repeated with the last three sieves; an 11-12 micron sieve (250x1400 mesh), an 8-9 micron sieve (325x2300 mesh), and ending with a 5-6 micron sieve (510x3600 mesh). Vacuum was used periodically for the smaller sized sieves. The bottom of each sieve screen was dabbed with a Kimwipe ${ }^{\mathrm{TM}}$ to absorb excess supernate on the sieve screen before drying overnight at $50{ }^{\circ} \mathrm{C}$. The sieves were then reweighed.

\section{Experiment 3.2}

$5.0454 \mathrm{~g}$ of slurry simulant was added to a weighing cup, diluted in $15 \mathrm{~mL}$ of previously filtered supernate and then poured into a pre-weighed pre-wetted 38 micron sieve which was the top sieve of a stack consisting of the pre-weighed and pre-wetted 38 micron sieve, a 32 micron sieve and a 25 micron sieve. The vibratory sieve shaker was put in the micro mode, set at an interval time of 10 secs and a total sieve time of $10 \mathrm{~min}$. The slurry solution that collected in the HDPE holder was filtered through a 0.45 micron filter and then re-circulated through the sieves. This eliminated the need to keep using additional filtered supernate and the sieving was easier with 'clean' supernate solution. After 10 mins the top sieve was removed. The wet sieving system was re-assembled and the sieves where shaken for 10 mins again. This pattern was repeated down to the last sieve in a three sieve stack. The final resulting slurry solution which collected in the HDPE reservoir was filtered through a 0.45 micron filter and used with the next set of sieves. Next, $1.0427 \mathrm{~g}$ of slurry simulant was added to a weighing cup, diluted in $15 \mathrm{~mL}$ of previously filtered supernate and then poured into a clean sieve, that was the size of the last sieve screen in the previous stack (25 microns), which was the top sieve of a four sieve stack which also had a pre-weighed, pre-wetted 20 micron sieve, a 16-18 micron sieve (165x1400 mesh), and a 12-14 micron sieve (200x1400 mesh), respectively. The pattern was repeated using the last three sieves (11-12 micron sieve (250x1400 mesh)), an 8-9 micron sieve (325x2300 mesh), and a 5-6 micron sieve (510x3600 mesh) except $0.5198 \mathrm{~g}$ of slurry was diluted in $15 \mathrm{~mL}$ of previously filtered supernate and then sieved. Vacuum was used periodically for the smaller sized sieves. The bottom of each sieve screen was dabbed with a Kimwipe ${ }^{\mathrm{TM}}$ to absorb excess supernate on the sieve screen before drying overnight at $50{ }^{\circ} \mathrm{C}$. The sieve was then reweighed.

\section{Experiment 3.3}

$5.1435 \mathrm{~g}$ of slurry simulant was added to a weighing cup, diluted in $15 \mathrm{~mL}$ of previously filtered supernate and then poured into a pre-weighed pre-wetted 38 micron sieve which was the top sieve of a stack consisting of the pre-weighed and pre-wetted 38 micron sieve, a 32 micron sieve and a 25 micron sieve. The vibratory sieve shaker was put in the micro mode, set at an interval time of 10 secs and a total sieve time of $10 \mathrm{~min}$. The slurry solution that collected in the HDPE holder was filtered through a 0.45 micron filter and then re-circulated through the sieves. This eliminated the need to keep using additional filtered supernate and the sieving was easier with 'clean' supernate solution. After 10 mins the top sieve was removed. The wet sieving system was re-assembled and the sieves where shaken for 10 mins again. This pattern was repeated down to the last sieve in a three sieve stack. The final resulting slurry solution which collected in the HDPE reservoir was filtered through a 0.45 micron filter and used with the next set of sieves. This pattern was repeated for the next three sieves (20 micron sieve, a 16-18 micron sieve (165x1400 mesh), and a 12-14 micron sieve (200x1400 mesh)) except $1.3053 \mathrm{~g}$ of slurry simulant was diluted in $15 \mathrm{~mL}$ of previously filtered supernate and then sieved. This same pattern was repeated for the final three sieves (11-12 micron sieve (250x1400 mesh), an 8-9 micron sieve (325x2300 mesh), and a 5-6 micron sieve (510x3600 mesh)) except $0.5694 \mathrm{~g}$ of slurry simulant was added to a weighing cup, diluted in $15 \mathrm{~mL}$ of previously filtered supernate and then sieved. The bottom of each sieve screen was dabbed with a Kimwipe ${ }^{\mathrm{TM}}$ to absorb excess supernate on the sieve screen before drying overnight at $50{ }^{\circ} \mathrm{C}$. The sieve was then re-weighed. Note: In experiment 3.3, each time more slurry was sieved it was not sieved 
through the smallest screen of the previous stack. A mathematical subtraction was used to account for the insoluble solids that should be removed from the prior sieve screen.

Experiments 3.3, 4.1-4.2, 5.1-5.2, 6.1-6.2 and 7.1-7.2 which were performed with Batch 3 Tank 40 Test 3, Tank 40 Drum 3 or CETL Sludge Batch 2 slurry simulants were done in a manner analogous to Experiment 3.3 except that the sieving done with water as the re-circulating fluid was not done using the sieve shaker but by hand. Experiments 4.2-4.2 and 5.1-5.3 were done with Tank 40 Drum 3 simulant and the following sieves in microns were used : 32, 25, 20, 16-18 (165x1400 mesh), 12-14 (200x1400 mesh), 11-12 (250x1400 mesh), 8-9 (325x2300 mesh), 6-7 (450x2750 mesh) and a 5-6 (510x3600 mesh). CETL Sludge Batch 2 was sieved with the following size sieves (in microns): 150, 75, 45, 32, 25, 16-18 (165x1400 mesh), 12-14(200x1400 mesh), 11-12 (250x1400 mesh), 8-9 (325x2300 mesh), 6-7 (450x2750 mesh) and a 5-6 (510x3600 mesh). See Appedices A-D for details.

\section{Experiments 3.4, 5.3 and 7.3}

The results from Experiments 3.1-3.3, 5.1-5.2 and 7.1-7.3 were skewed due to the excess weight of the dissolved solids which became stuck on the sieves when they were dried after the sieving was complete. Therefore, a dissolved solids correction factor was needed and arrived at from the following experiments.

Pre-weighed sieves of the same size as those used in experiments 3.1-3.3, 5.1-5.2 and 7.1-7.2 were stacked and then corresponding supernate from Batch 3 Tank 40 Test 3, USC Tank 40 or CETL Sludge batch 2 simulant was poured through the sieves and allowed to drain out. The sieves were shaken off by hand then dabbed with a Kimwipe ${ }^{\mathrm{TM}}$ before being dried overnight at $50^{\circ} \mathrm{C}$. The sieves were re-weighed. This progression was repeated twice. The average weight of dissolved solids that collected on each size sieve was then subtracted from the difference of weight obtained before and after sieving the simulant slurry with supernate except for Experiment 5.3 in which case only one set of data from the dissolved solids experiment was used. Please see the appropriate data table in Appendix B for specific details. 
WSRC-TR-2005-00077

Revision 0

This page intentionally left blank. 


\subsection{RESULTS}

\section{NIST 1984 Standard}

Because of the different weave of the mesh of the sieves it was necessary to 'calibrate' the sieves or determine the size of particles being retained on each of the different sieves, if possible. The NIST 1984 standard, which is used for Microtrac analysis, was chosen because of its size distribution, irregularly shaped particle morphology, resistance to fracture on handling and low level of aggregation. The micro sieves used in experiments 1.1-1.4 include the 25 micron, 20 micron, 16-18 micron (165x1400 mesh), 1214 micron (200x1400 mesh), 11-12 micron (250x1400 mesh) and 8-9 micron (325x2300 mesh) size sieves. Solids collected from the 12-14 micron sieve (200x1400 mesh), 11-12 micron sieve (250x1400 mesh), and 8-9 micron sieve (325x2300 mesh) (from experiments 1.3 or 1.4) were submitted for Microtrac analysis and the results are contained in Appendix D. There were not enough solids on the 1618 micron sieve to submit for Microtrac or SEM analysis. An additional experiment was done in which the NIST standard was sieved through the 8-9 micron sieve and then through a 5-6 micron sieve to test the retention of the 5-6 micron sieve. Particles collected on the 5-6 micron sieve were submitted for Microtrac analysis. Microtrac data indicated the following:

- For the 20 micron sieve $\sim 90$ of the particles were larger than 21 microns on a volume basis.

- For the $12-14$ micron sieve $100 \%$ of the particles were above 15 microns on a volume basis.

- For the 11-12 micron sieve $\sim 90 \%$ of the particles were above 12 microns on a volume basis.

- For the 8-9 micron sieve $\sim 90 \%$ of the particles were above 9 microns on a volume basis.

- For the 5-6 micron sieve $100 \%$ of the particles were above 6 microns on a volume basis.

SEM data collected on the solids on the 25 micron sieve indicates $90 \%$ particles (based on 50 randomly chosen and measured particles) were greater than 25 microns. This is illustrated in Figure Figure 3.1. 


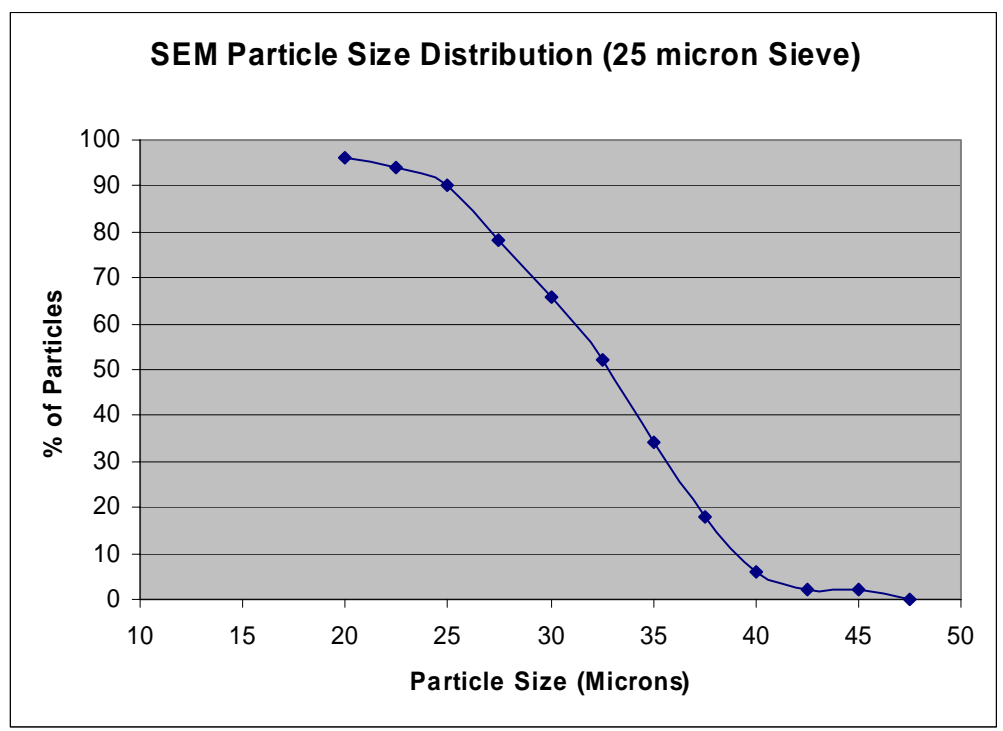

Figure 3.1 SEM analysis of particles collected on 25 micron sieve. $\sim 90 \%$ of the particles are above 25 microns. Fifty randomly chosen particles were measured and graphed.

Shown in Figure 3.2 is a SEM of the 1984 NIST standard in which one can clearly see the different morphology of the particles. This lends more credence for using the NIST standard to calibrate the size of particles being retained by each sieve because the particles in sludge slurry are probably not all round.

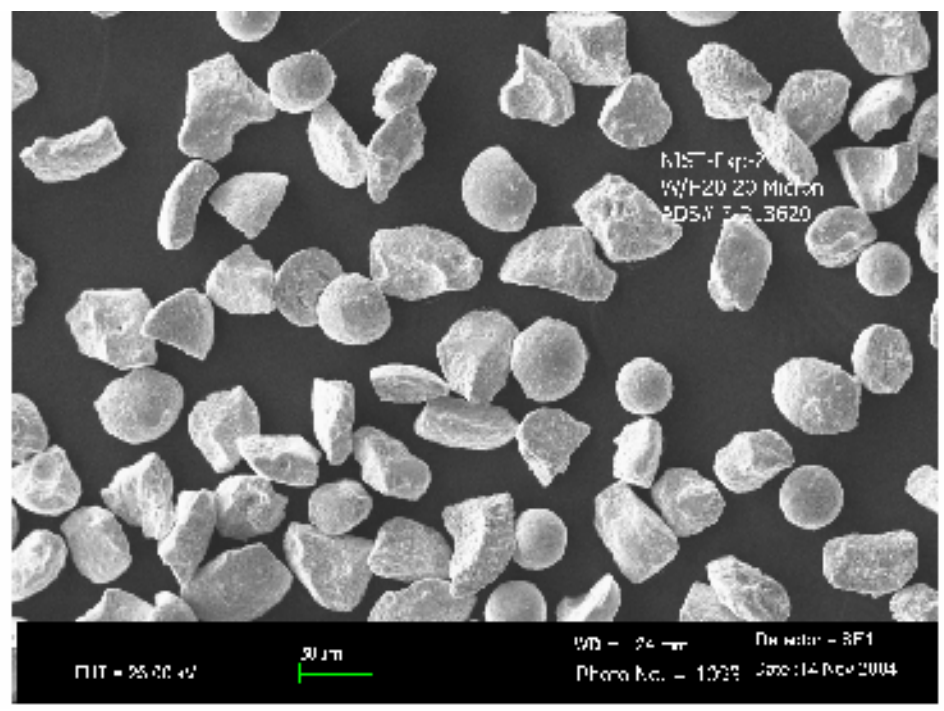

Figure 3.2 SEM of particles collected on 20 micron sieve screen.

A picture of the dried sieves used in Experiment 1.3 is shown in Figure 3.3 below and the experimental results obtained from sieving the NIST 1984 standard are shown in Figure 3.4. 


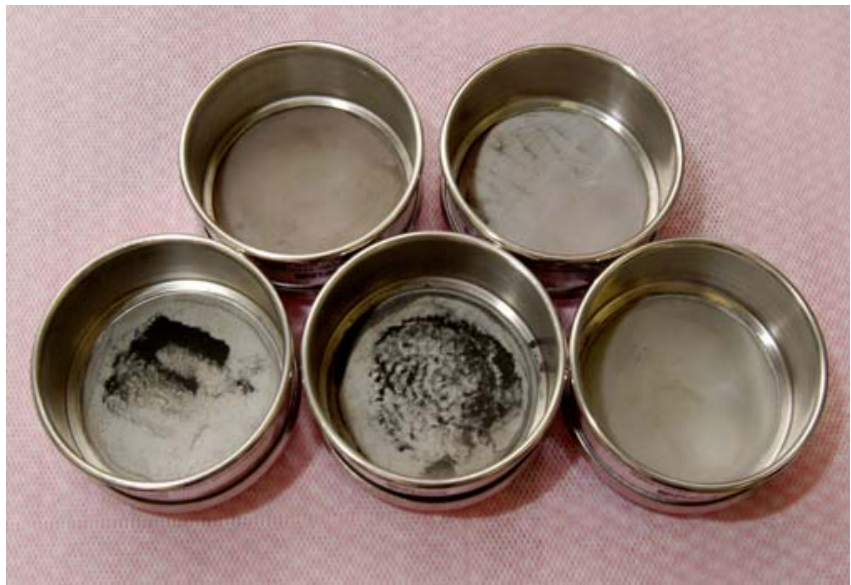

Figure 3.3 Dried sieves used in experiment 1.3. From top left to right, 25 micron sieve, 20 micron sieve, 12-14 micron sieve (200x1400 mesh), 11-12 micron sieve (250x1400 mesh) and an 8-9 micron sieve (325x2300 mesh), respectively.

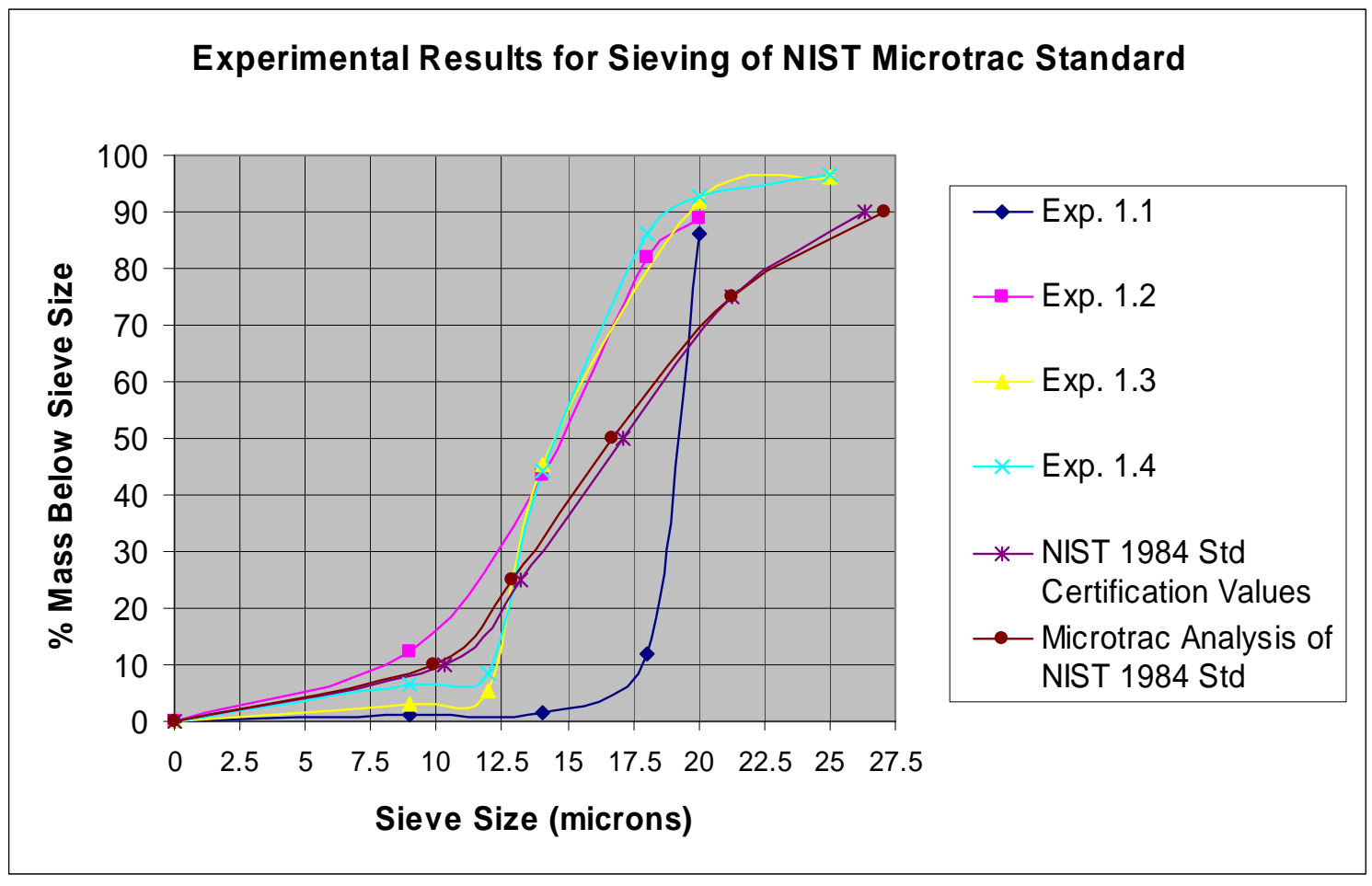

Figure 3.4 Experimental results obtained from sieving NIST1984 standard.

Experiment 1.1 was performed without the use of water during the sieving process. Experiments 1.2-1.4 were performed with water and the time of sieving varied. However, the results were consistent regardless of sieving time. The sieve sizes used to graph experiments 1.1-1.4 is based upon the manufacturer's upper size limit given for the sieve and is supported by Microtrac data. In other words, the sieve size used for the 12-14 micron sieve was 14. At larger micron values, the graph in Figure 4 indicates that the \% mass fraction of the sample below 20 microns is higher than Microtrac data indicates. One possible reason for this may be that the standard is being broken into smaller particles during the 
sieving process. However, these experiments were done both by hand and with the use of a sieve shaker and because the results obtained were very similar this seems unlikely. The important point is that the sieves are retaining particles larger than the specified micron size of the sieves.

\section{Batch 3 Tank 40 Test 3 Simulant Slurry}

Experiments 2.1-2.2 were performed with the use of a sieve shaker. Experiment 2.3 was performed by hand using water to rinse the slurry through the sieves. For specific details see the experimental section and data contained in Appendix A. The graph in Figure 3.5 highlights three important findings. The first is that a sieving experiment using over five grams of slurry blinded the smaller size sieves (Exp. 2.1) and vacuum was employed which tended to stick the particles to the sieve and no amount of rinsing could loosen them. The second important feature is that the experimental results are reproducible whether they are done with the use of a sieve shaker or by hand. The third feature is that in experiments $2.1-2.3 \sim 18 \%$ of the insoluble solids were larger than 38 microns yet this is not reflected in the Microtrac data. There are two possible reasons for this. One is that a representative sample was not put into the Microtrac instrument. The other possible reason is the large dilution done for Microtrac analysis. The large dilution changes the $\mathrm{pH}$ of the sample and begins to dissolve $\mathrm{M}_{\mathrm{n}}(\mathrm{OH})_{\mathrm{x}}$ and $\mathrm{M}_{\mathrm{n}} \mathrm{O}_{\mathrm{x}}$ species. If a large dilution of the slurry is done and more 'marbles' are created as compared to the number of 'boulders' present, then the volume data will be skewed and indicate there is a larger volume of small particles present. Smaller particles also cause more laser light scattering which skew the data further. The sieving experiments, on the other hand were performed with a much larger sample size and a much smaller dilution. The boulders in the present case are sand and are similar to the solids collected on the largest sieve shown in Figure 3.6.

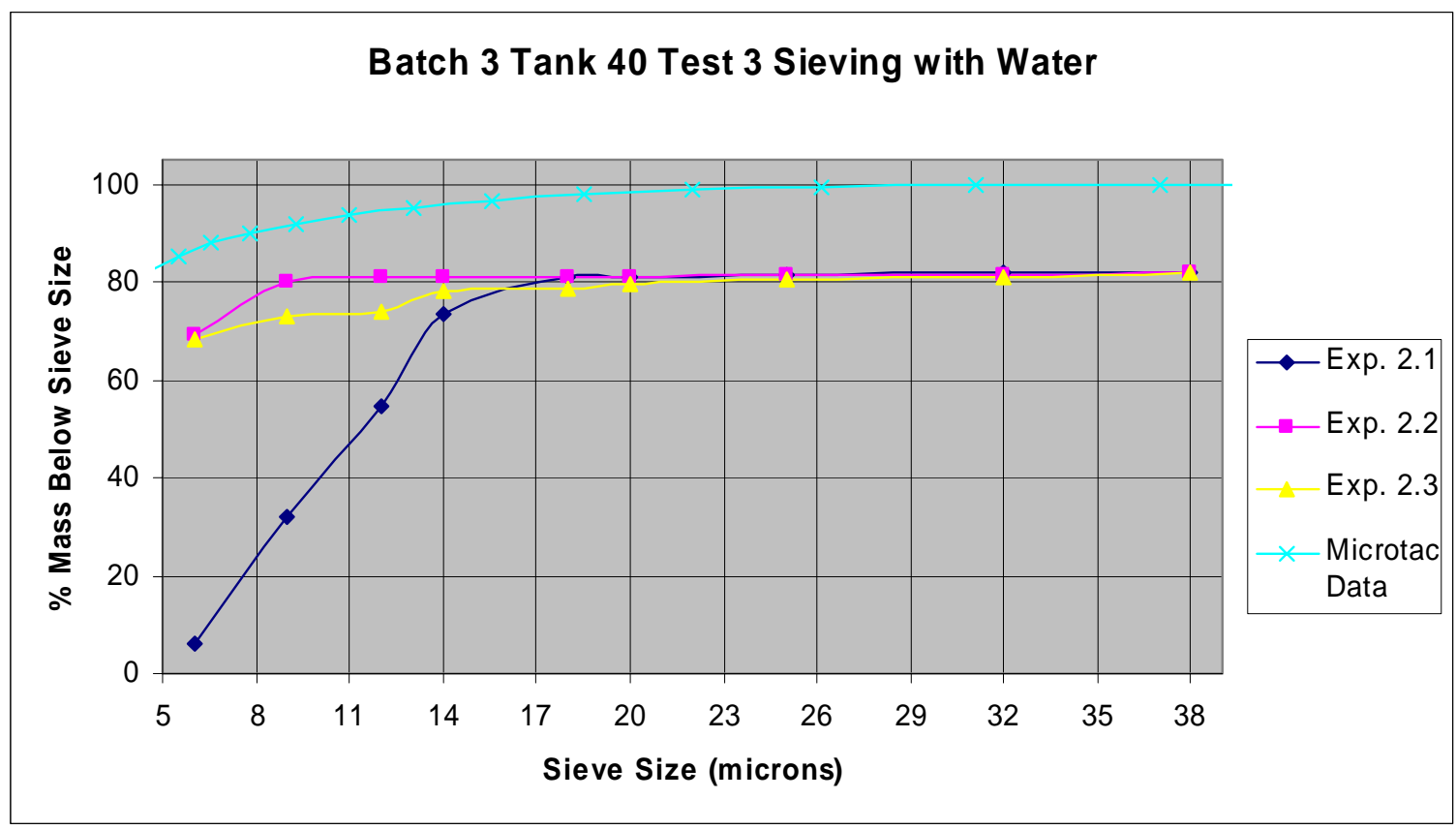

Figure 3.5 Batch 3 Tank 40 Test 3 simulant slurry sieving results using water as re-circulating fluid or as the rinsing solution if done by hand (\% Mass Below Sieve Size vs Sieve Size (microns)).

Experiments 3.1-3.3 were performed using a sieve shaker and supernate as the re-circulating fluid. For specific details see the experimental section. A picture of the dried sieves used in experiment 3.2 is shown in Figure 3.6 and the experimental results are graphed in Figure 3.7. 


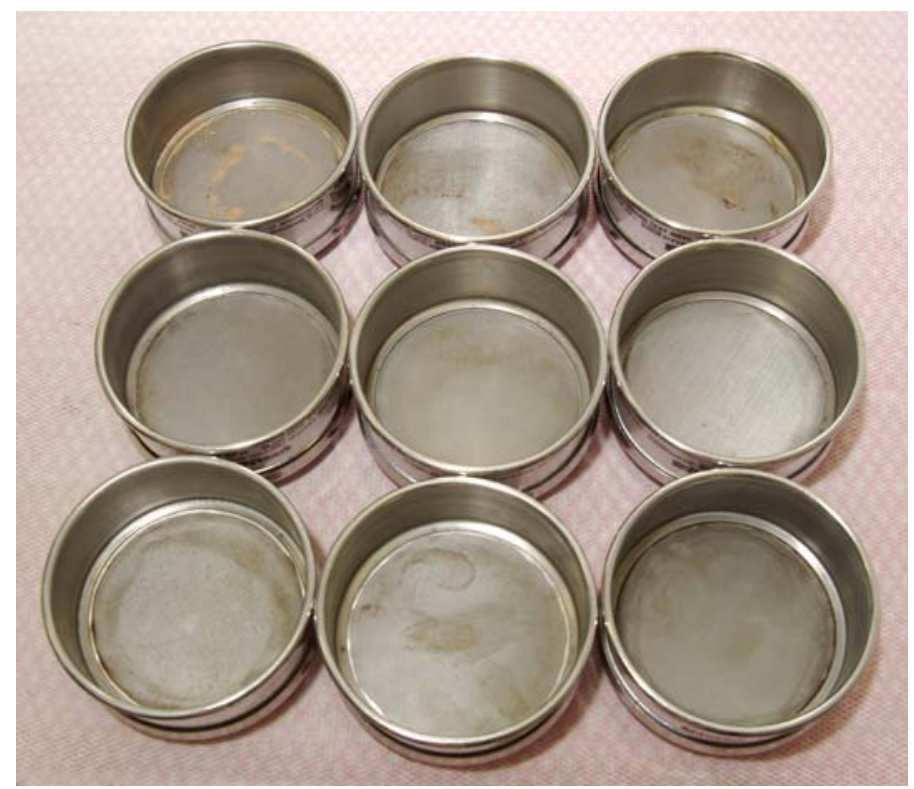

Figure 3.6 Sieves used in experiment 3.2. From top left to right 38 micron sieve, 32 micron sieve, 25 micron sieve, 20 micron sieve, 16-18 micron sieve (165x1400 mesh), 12-14 micron sieve (200x1400 mesh), 11-12 micron sieve (250x1400 mesh), 8-9 micron sieve (325x2300 mesh), and a 5-6 micron sieve (510x3600 mesh), respectively.

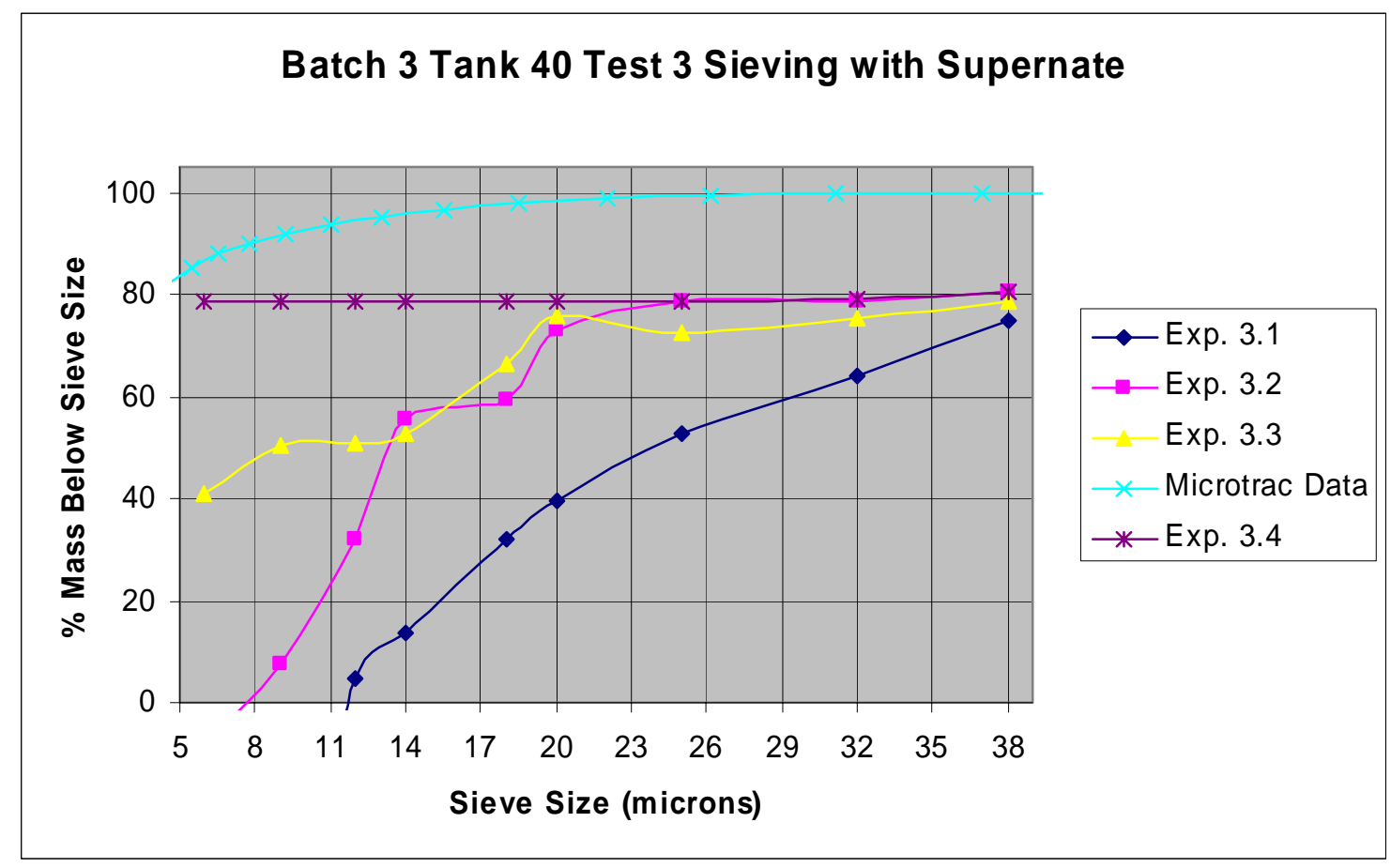

Figure 3.7 Batch 3 Tank 40 Test 3 simulant slurry sieving results using supernate as re-circulating fluid (\% Mass Below Sieve Size vs Sieve Size (microns)). Experiment 3.4 is the corrected and averaged data based upon soluble solids in the supernate. 
The results from experiment 3.1 indicate that too much slurry was used and when vacuum was employed it tended to stick the particles to the sieve and no amount of rinsing could loosen them. The results from all three experiments (3.1-3.3) were poor due to residual supernate solids being deposited on the sieves. The extra mass is attributed to dissolved solids present in the supernate. The dissolved solids become even more of a problem with smaller sieves. It should be noted that if a negative value was obtained for the weight difference between the clean dry sieve and the dry sieve after sieving, its contribution was counted as zero for the \% of insoluble solids on the sieve. However, once the dissolved solids are subtracted out, the results appear to be much better. Exp. 3.4 is an average of experiments 3.1 and 3.2 with the average (from two experiments) dissolved solids subtracted out. It should be noted that when the dissolved solids were subtracted out, if a negative value was obtained it was counted as zero when the mass loss was subtracted from 100 to obtain the \% mass below a specific sieve size (y-axis). This may be a point of debate (see Appendix C). The resulting data from Experiment 3.4 is closer to the results obtained when sieving with water (see Experiments 2.2-2.3 in Figure 3.5). Microtrac data is added for comparison.

\section{Tank 40 Drum 3 Simulant Slurry}

Experiments 4.1-4.2 and 5.1-5.3 were performed using Tank 40 Drum 3 simulant. This simulant slurry has a bimodal distribution of particles (based on Microtrac data) and there was interest in determining if the results obtained from sieving of the simulant slurry would reflect this type of distribution.

Experiments 4.1-4.2 were done in a similar manner to Experiments 2.1-2.2; the slurry was rinsed through the sieves using DI $\mathrm{H}_{2} \mathrm{O}$. For specific details see the experimental section and Appendices A-C. The experimental results are graphed in Figure 3.8.

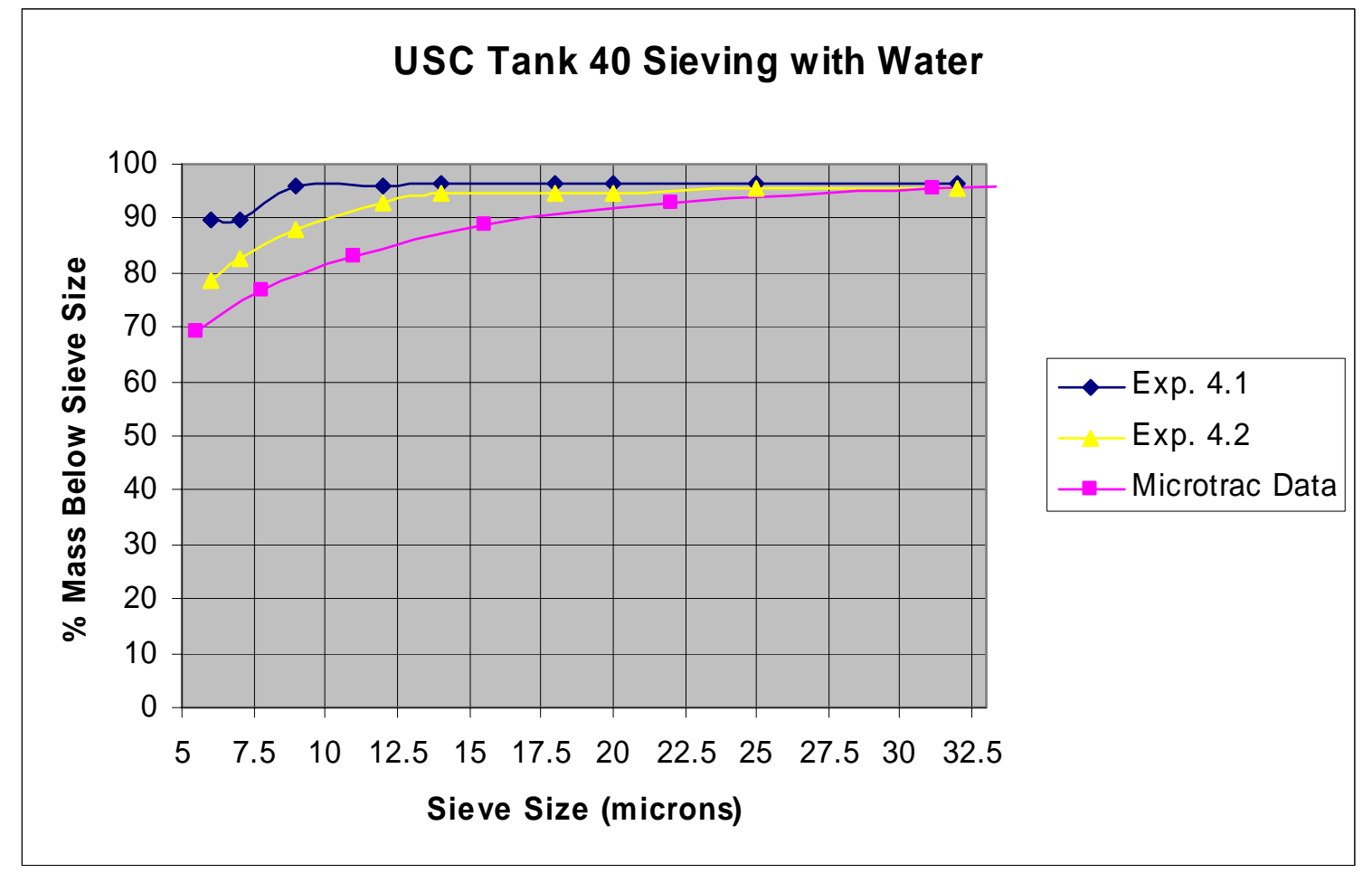

Figure 3.8 Tank 40 Drum 3 simulant sieving results using water as re-circulating fluid (\% Mass Below Sieve Size vs Sieve Size (microns)). 
Experiments 4.1 and 4.2 show good reproducibility and trend in the same direction as the Microtrac data. As stated earlier this need not be the case because the conditions of analysis are very different. Unfortunately, the smallest sieve available was the 5-6 micron sieve and the second node of the bimodal distribution was under 5 microns and it not reflected in Figure 3.8.

Experiments 5.1-5.2 were done in an analogous manner to Experiments 4.1 and 4.2 except a sieve shaker was used during the sieving process and supernate was used as the re-circulating fluid. Experiment 5.3 was done a similar manner to Experiment 3.4. For specific details see Appendices A-C and the experimental section. The experimental results are graphed in Figure 3.9.

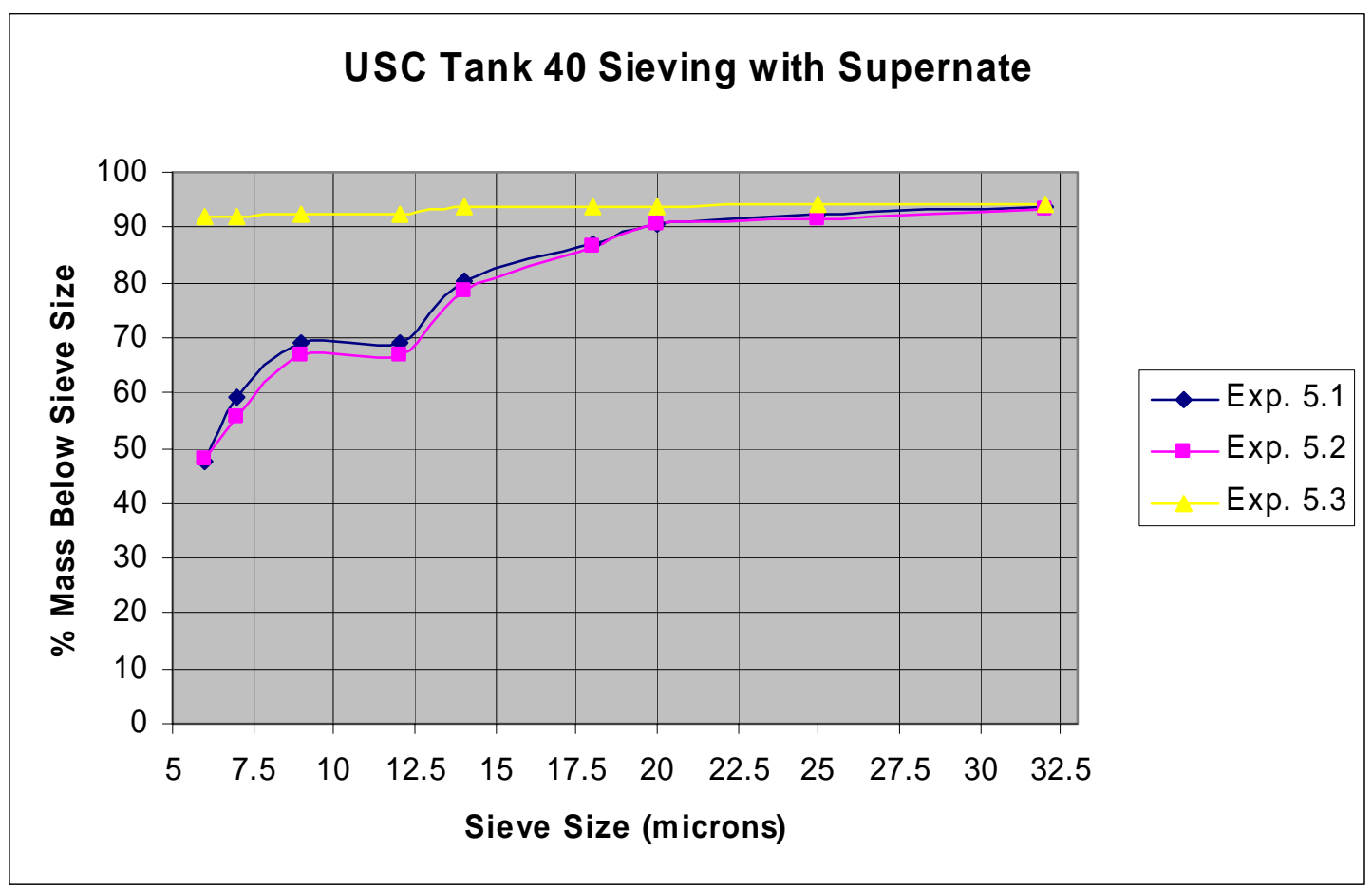

Figure 3.9 Tank 40 Test 3 simulant sieving results using supernate as re-circulating fluid (\% Mass Below Sieve Size vs Sieve Size (microns)). Experiment 5.3 is the corrected and averaged data based upon soluble solids in the supernate.

Experiments 5.1-5.2 show good reproducibility, which also means the sieves are being cleaned well between uses. Again in Figure 11, the bimodal size distribution of particles in Tank 40 Drum 3 simulant slurry is not evident. The substantial mass increase on the smaller sieves due to the dissolved solids in the samples is evident. Once the data was corrected for dissolved solids (Exp. 5.3) the resulting \% mass below sieve size (y-axis) increased substantially. The corrected data is more similar to that seen in Experiments 4.1-4.2. The corrected average is still within 20\% of the Microtrac data.

\section{CETL Sludge Batch 2 Slurry Simulant}

Experiments 6.1-6.2 and 7.1-7.3 were performed using CETL Sludge Batch 2 slurry simulant. This simulant slurry also has a bimodal size distribution of particles. Experiments 6.1-6.2 were performed by hand using water to rinse the re-circulating fluid through the sieves. Also, $\sim 10$ grams of simulant slurry was used for the first three sieves because of their larger size and the larger particle size based on 
Microtrac data. The experimental results are graphed in Figure 3.10. For specific details see Appendices A-C and the experimental section.

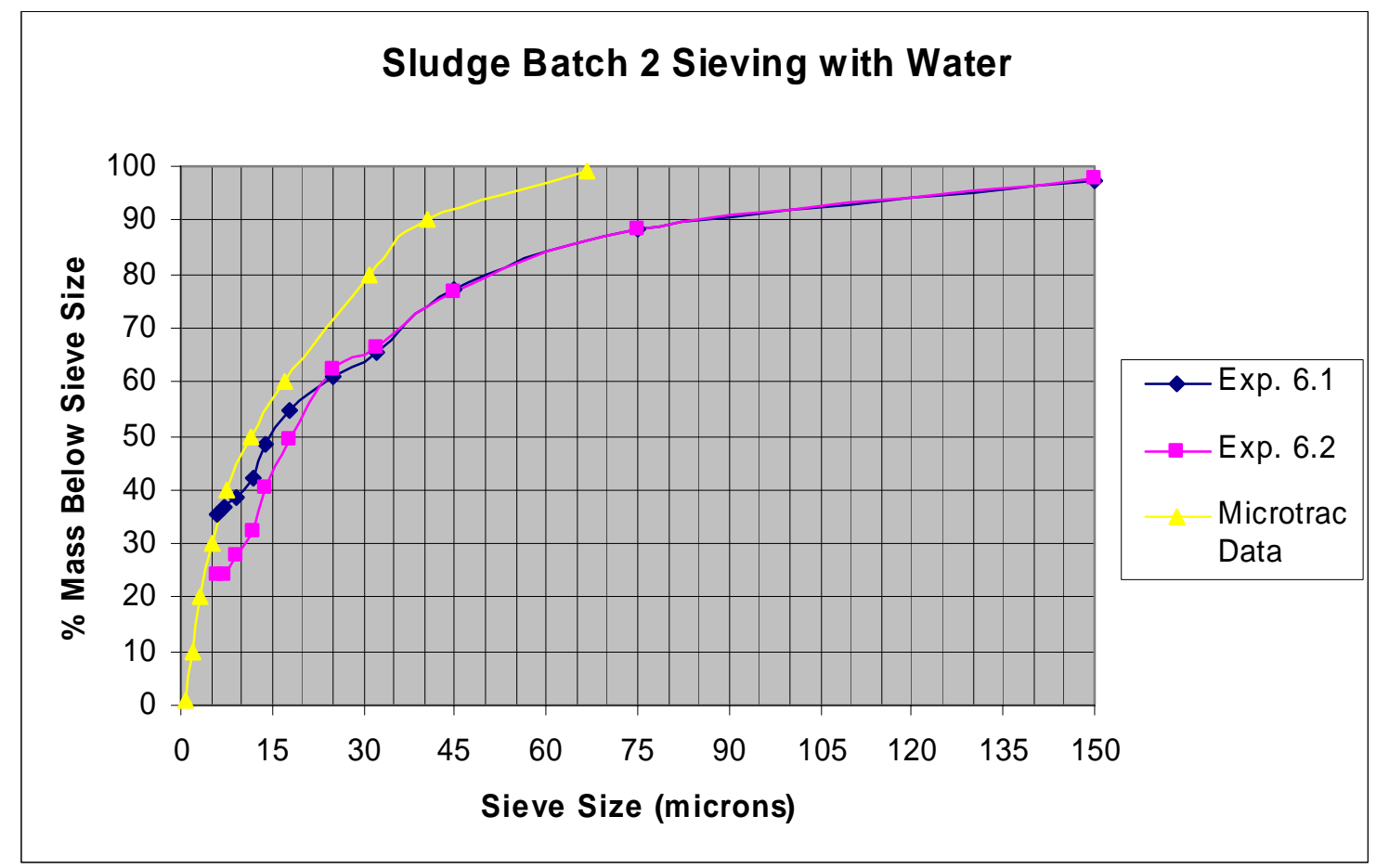

Figure 3.10 CETL Sludge Batch 2 simulant sieving results using water as re-circulating fluid (\% Mass Below Sieve Size vs Sieve Size (microns)).

Good reproducibility was also seen with this simulant slurry in Experiments 6.1-6.2. The bimodal distribution may be slightly evident in the decrease of the slope in the lines between 32 microns and 25 microns. This decrease reflects the same decrease in seen in the \% channel information from Microtrac data. However, if we did not have advance knowledge of the bimodal distribution, it would be impossible to pick out such a subtlety and reliably say that is was due to a bimodal distribution. Again, a majority of the particles in the second node of the bimodal distribution were smaller than the smallest size sieve.

Experiments 7.1-7.2 were performed in a similar manner, and using the same size sieves, as Experiments 6.1-6.2 except the sieve shaker was used and supernate was used as the re-circulating fluid. In addition, $\sim 5$ grams of slurry was used for the largest three sieves (150 microns, 75 microns, 45 microns, 32 microns) instead of $\sim 10$ grams. The weight of the slurry for the reaming sieving was similar to Experiments 6.1-6.2. The experimental results are graphed in Figure 3.11. For specific details see Appendices A-C 


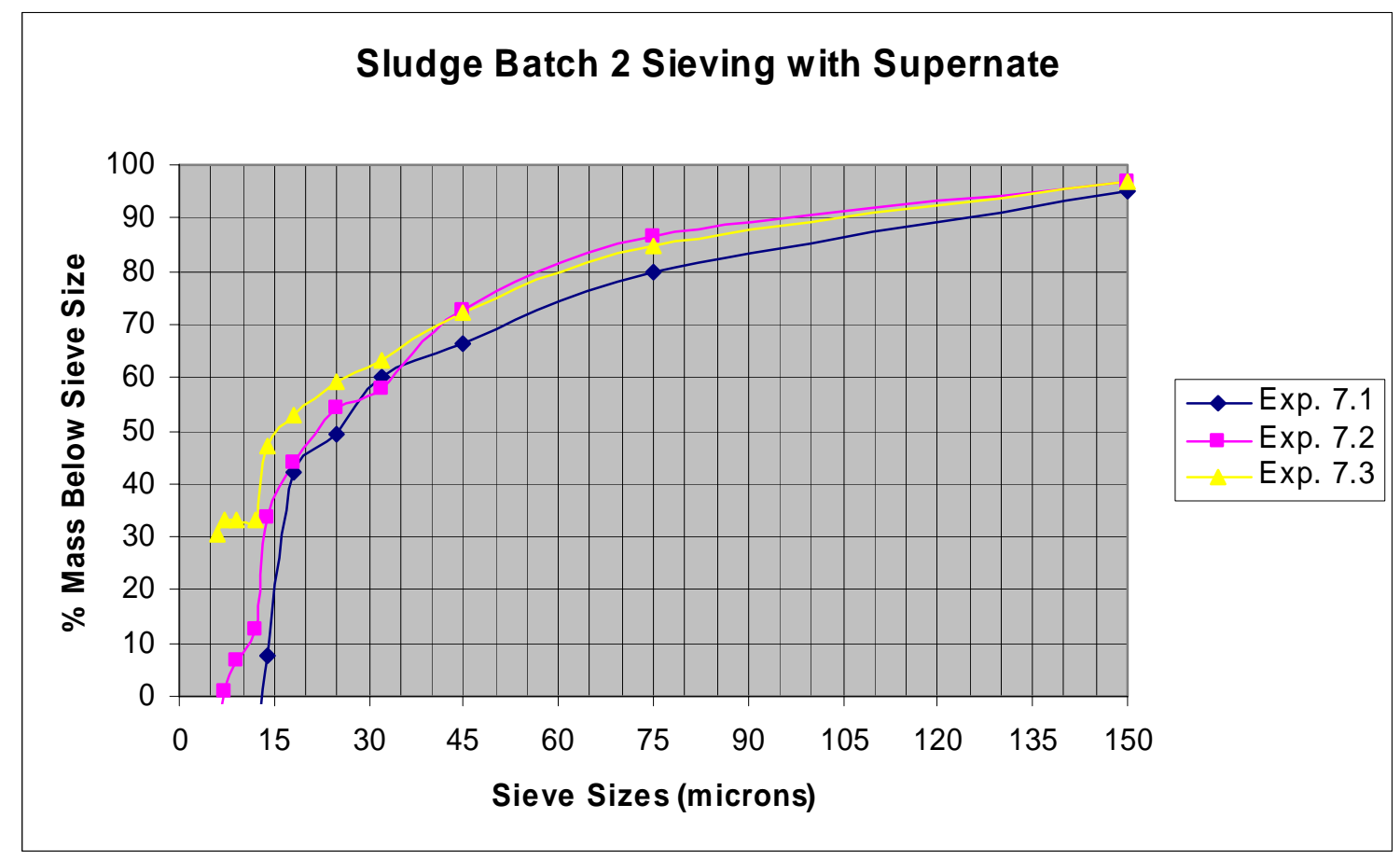

Figure 3.11 CETL Sludge Batch 2 simulant sieving results using supernate as re-circulating fluid (\% Mass Below Sieve Size vs Sieve Size (microns)).

Experimental data from Experiments 7.1-7.2 contained large negative percentages for the \% mass below the smallest sieve size due to the dissolved solids drying on the sieves when using supernate as the recirculating fluid. However upon subtraction of the dissolved solids, the average line (Exp. 7.3) is in good agreement with Microtrac data and the data from the experiments done using water as the re-circulating fluid. The bimodal distribution of particles in the simulant slurry cannot be seen in Experiments 7.1-7.2 nor is it evident in the dissolved solids corrected data (Exp. 7.3).

\section{Sieve Cleaning}

The sieves were cleaned by removing as much dried slurry as possible using a water rinse. Then, the sieves were submerged in 2 volume \% nitric acid solution for a period of five minutes, rinsed with DI water and transferred to a $1 \mathrm{M}$ oxalic acid solution for five minutes. The sieves were then rinsed with DI water and placed sieve foil side up in a Sonicator bath for no longer than three minutes (damage may result to the sieves if left in Sonicator longer than three minutes). The sieves were again rinsed with DI water and if there was any resulting residue on the sieves, the process was repeated. In many cases the sieve weight did not change except in the fourth decimal place between experimental runs. Also, the repeatability of the experiments suggests the sieve cleaning protocol is sufficient and can be implemented in the shielded cells. 
WSRC-TR-2005-00077

Revision 0

This page intentionally left blank. 


\subsection{CONCLUSIONS}

Sieving simulant sludge slurries to determine approximate particle size distribution appears to be a viable option to Microtrac. However, only volume data can be obtained using the sieving method whereas Microtrac analysis gives both volume and number data. The experimental protocol which involved duplicate sieving experiments of a NIST standard (to check the particle size retention of the sieves) and three non-radioactive slurry simulants were carried out using DI water only and filtered supernate and DI water (to check the accuracy of the method versus Microtrac data), respectively.

Particle size determinations using the wet sieving method with simulant slurry and filtered supernate as the re-circulating fluid resulted in data which needed to be corrected.

However, upon subtracting out the average dissolved solids left on the sieves, as a result of the supernate, the results were comparable to that obtained from sieving with water. It should be noted that approximately $250 \mathrm{~mL}$ of each of three simulant slurries was necessary to have enough filtered supernate available to carry out the experiments. Therefore, depending upon the size of the sample using supernate to sieve may not be viable.

The design of the experimental equipment was sufficient initially but some pieces of the equipment began failing over time due to the caustic nature of the supernate and the vibrations from the sieve shaker. It is therefore recommended that upgrades to the experimental equipment be done before implementation into the SRNL shielded cells. Theses upgrades include using manipulator friendly connections, changing brass parts for stainless steel parts, using Teflon rather than polycarbonate, and possibly a change of pumps used to re-circulate the sieving fluid. 
WSRC-TR-2005-00077

Revision 0

This page intentionally left blank. 


\subsection{RECOMMENDATIONS/PATH FORWARD}

Based upon the results obtained, it is recommended that this method be implemented in the shielded cells of SRNL upon upgrades and approval from ITS and it should be used whenever particle size determination is necessary on a volume basis. Consideration should also be given to combining the sieving of particles with SEM analysis. By doing this, a better particle size distribution of the particles collected on the sieves can be attained. However, this may not be possible when working with samples that pose a radiological hazard.

The upgrades necessary before this can be done include using manipulator friendly hose connections, changing brass parts for stainless steel parts, using Teflon rather than polycarbonate, and possibly a change of pumps used to re-circulate the sieving fluid. 
WSRC-TR-2005-00077

Revision 0

This page intentionally left blank. 


\subsection{REFERENCES}

${ }^{1}$ Schramm, G. A Practical Approach to Rheology and Rheometry, Gebrueder HAAKE GmBH, D-76227 Karlsruhe, Dieselstrasse 4, Federal Republic of Germany.

${ }^{2}$ T.L. Fellinger, "Results of the Shielded Cells Sludge Batch 2 Phase II Testing SRT-GDP-2003-00078. 
WSRC-TR-2005-00077

Revision 0

This page intentionally left blank. 


\subsection{ACKNOWLEDGEMENTS}

The author would like to acknowledge ITS (Immobilization Technology Section) for use of lab space to perform the experiments, Terri Fellinger (for weight percent solids information, technical review and helpful discussions), Frank Pennebaker (spreadsheet review), David Koopman (for material characterization data), Wilson Smith (for providing Microtrac analysis and discussions), Mike Summer (for providing SEM data and discussions) and Don Blankenship (for helpful discussions). 
WSRC-TR-2005-00077

Revision 0

This page intentionally left blank. 
WSRC-TR-2005-00077

Revision 0

APPENDIX A

DATA TABLES FROM EXPERIMENTS 2.1-2.3, 3.1-3.3, 4.1-4.2, 5.1-5.2, 6.1-6.2 AND 7.1-7.2 
Table A.1 Experimental Data from Experiments 2.1 - 2.3.

\begin{tabular}{|c|c|c|c|c|c|}
\hline \multirow{2}{*}{\multicolumn{2}{|c|}{$\begin{array}{l}\text { Exp. } 2.1 \\
\text { Sieved with Water Using } \\
\text { Shaker }\end{array}$}} & & \multicolumn{2}{|c|}{ Total Sample Used $(\mathrm{g})=$} & 5.1150 \\
\hline & & & \multicolumn{2}{|c|}{ Insoluble Solids $(\mathrm{g})=$} & 0.6010 \\
\hline $\begin{array}{c}\text { Sieve Size } \\
\text { (microns or } \\
\text { mesh) }\end{array}$ & $\begin{array}{l}\text { Dry Wt of } \\
\text { Sieve }(\mathrm{g})\end{array}$ & $\begin{array}{l}\text { Wt. After } \\
\text { Sieving } \\
\text { Slurry and } \\
\text { Drying (g) }\end{array}$ & $\begin{array}{l}\text { Dry Wt of } \\
\text { Sieve }(\mathrm{g}) \text { - } \\
\text { Wt. After } \\
\text { Sieving } \\
\text { Slurry and } \\
\text { Drying }(\mathrm{g})\end{array}$ & $\begin{array}{c}\% \text { of } \\
\text { Insoluble } \\
\text { Solids } \\
\text { Collected on } \\
\text { Sieve }\end{array}$ & $\begin{array}{l}\text { \% of Solids } \\
\text { Below Sieve } \\
\quad \text { Size }\end{array}$ \\
\hline 38 & 80.5326 & 80.6399 & 0.1073 & 17.85 & 82.15 \\
\hline 32 & 80.5693 & 80.5718 & 0.0025 & 0.42 & 81.73 \\
\hline 25 & 72.9787 & 72.9808 & 0.0021 & 0.35 & 81.38 \\
\hline 20 & 71.4555 & 71.4567 & 0.0012 & 0.20 & 81.18 \\
\hline $\begin{array}{c}16-18 \\
(165 \times 1400)\end{array}$ & 84.3403 & 84.3402 & -0.0001 & 0.00 & 81.18 \\
\hline $\begin{array}{c}12-14 \\
(200 \times 1400)\end{array}$ & 75.3484 & 75.3960 & 0.0476 & 7.92 & 73.28 \\
\hline $\begin{array}{c}11-12 \\
(250 \times 1400)\end{array}$ & 81.2208 & 81.3317 & 0.1109 & 18.45 & 54.83 \\
\hline $\begin{array}{c}8-9 \\
(325 \times 2300)\end{array}$ & 75.5930 & 75.7301 & 0.1371 & 22.81 & 32.01 \\
\hline $\begin{array}{c}5-6 \\
(510 \times 3600) \\
\end{array}$ & 80.6794 & 80.8347 & 0.1553 & 25.84 & 6.17 \\
\hline \multicolumn{3}{|l|}{ Exp. 2.2} & \multicolumn{2}{|c|}{ Total Sample Used $(\mathrm{g})=$} & 5.0528 \\
\hline \multicolumn{2}{|c|}{$\begin{array}{l}\text { Sieved with Water Using } \\
\text { Shaker }\end{array}$} & & \multicolumn{2}{|c|}{ Insoluble Solids $(\mathrm{g})=$} & 0.5937 \\
\hline $\begin{array}{c}\text { Sieve Size } \\
\text { (microns or } \\
\text { mesh) }\end{array}$ & $\begin{array}{l}\text { Dry Wt of } \\
\text { Sieve }(g)\end{array}$ & $\begin{array}{l}\text { Wt. After } \\
\text { Sieving } \\
\text { Slurry and } \\
\text { Drying }(g)\end{array}$ & $\begin{array}{l}\text { Dry Wt of } \\
\text { Sieve (g) - } \\
\text { Wt. After } \\
\text { Sieving } \\
\text { Slurry and } \\
\text { Drying (g) }\end{array}$ & $\begin{array}{c}\% \text { of } \\
\text { Insoluble } \\
\text { Solids } \\
\text { Collected on } \\
\text { Sieve }\end{array}$ & $\begin{array}{c}\% \text { of Solids } \\
\text { Below Sieve } \\
\text { Size }\end{array}$ \\
\hline 38 & 80.0424 & 80.1506 & 0.1082 & 18.22 & 81.78 \\
\hline 32 & 81.1155 & 81.1168 & 0.0013 & 0.22 & 81.56 \\
\hline 25 & 72.9318 & 72.9318 & 0.0000 & 0.00 & 81.56 \\
\hline 20 & 73.4064 & 73.4085 & 0.0021 & 0.35 & 81.20 \\
\hline $\begin{array}{c}16-18 \\
(165 \times 1400)\end{array}$ & 83.6445 & 83.6445 & 0.0000 & 0.00 & 81.20 \\
\hline $\begin{array}{c}12-14 \\
(200 \times 1400)\end{array}$ & 83.7140 & 83.7144 & 0.0004 & 0.07 & 81.14 \\
\hline \multirow{2}{*}{\multicolumn{5}{|c|}{$\begin{array}{c}\begin{array}{c}\text { Total Sample Used }(\mathrm{g})= \\
\text { Insoluble Solids }(\mathrm{g})=\end{array}\end{array}$}} & 0.60 \\
\hline & & & & & 0.0703 \\
\hline $\begin{array}{c}11-12 \\
(250 \times 1400) \\
\end{array}$ & 75.5404 & 75.5391 & -0.0013 & 0.00 & 81.14 \\
\hline $\begin{array}{c}8-9 \\
(325 \times 2300)\end{array}$ & 75.5800 & 75.5809 & 0.0009 & 1.28 & 79.86 \\
\hline $\begin{array}{c}5-6 \\
(510 \times 3600) \\
\end{array}$ & 80.6572 & 80.6646 & 0.0074 & 10.53 & 69.33 \\
\hline
\end{tabular}


Table A.1 Continued. Experimental Data from Experiments 2.1 - 2.3.

\begin{tabular}{|c|c|c|c|c|c|}
\hline \multicolumn{3}{|c|}{$\begin{array}{l}\text { Exp. } 2.3 \\
\text { Sieved with Water By Hand }\end{array}$} & \multicolumn{2}{|c|}{$\begin{array}{c}\text { Total Sample Used }(\mathrm{g})= \\
\text { Insoluble Solids }(\mathrm{g})=\end{array}$} & $\begin{array}{l}5.2097 \\
0.6121\end{array}$ \\
\hline $\begin{array}{l}\text { Sieve Size } \\
\text { (microns or } \\
\text { mesh) }\end{array}$ & $\begin{array}{l}\text { Dry Wt of } \\
\text { Sieve }(g)\end{array}$ & $\begin{array}{l}\text { Wt. After } \\
\text { Sieving } \\
\text { Slurry and } \\
\text { Drying (g) }\end{array}$ & $\begin{array}{l}\text { Dry Wt of } \\
\text { Sieve (g) - } \\
\text { Wt. After } \\
\text { Sieving } \\
\text { Slurry and } \\
\text { Drying (g) }\end{array}$ & $\begin{array}{c}\% \text { of } \\
\text { Insoluble } \\
\text { Solids } \\
\text { Collected on } \\
\text { Sieve }\end{array}$ & $\begin{array}{c}\% \text { of Solids } \\
\text { Below Sieve } \\
\text { Size }\end{array}$ \\
\hline 38 & 80.5204 & 80.6323 & 0.1119 & 18.28 & 81.72 \\
\hline 32 & 80.5624 & 80.5670 & 0.0046 & 0.75 & 80.97 \\
\hline 25 & 80.5215 & 80.5232 & 0.0017 & 0.28 & 80.69 \\
\hline \multicolumn{5}{|c|}{$\begin{array}{l}\text { Total Sample Used }(\mathrm{g})= \\
\text { Insoluble Solids }(\mathrm{g})=\end{array}$} & $\begin{array}{l}1.1475 \\
0.1348\end{array}$ \\
\hline 20 & 71.4420 & 71.4438 & 0.0018 & 1.34 & 79.36 \\
\hline $\begin{array}{c}16-18 \\
(165 \times 1400) \\
\end{array}$ & 75.1031 & 75.1040 & 0.0009 & 0.67 & 78.69 \\
\hline $\begin{array}{c}12-14 \\
(200 \times 1400) \\
\end{array}$ & 75.3330 & 75.3339 & 0.0009 & 0.67 & 78.02 \\
\hline \multicolumn{5}{|c|}{$\begin{array}{c}\text { Total Sample Used }(\mathrm{g})= \\
\text { Insoluble Solids }(\mathrm{g})=\end{array}$} & $\begin{array}{l}0.5312 \\
0.0624\end{array}$ \\
\hline $\begin{array}{c}11-12 \\
(250 \times 1400) \\
\end{array}$ & 81.2040 & 81.2067 & 0.0027 & 4.33 & 73.69 \\
\hline $\begin{array}{c}8-9 \\
(325 \times 2300)\end{array}$ & 75.1270 & 75.1273 & 0.0003 & 0.48 & 73.21 \\
\hline $\begin{array}{c}5-6 \\
(510 \times 3600)\end{array}$ & 80.7907 & 80.7939 & 0.0032 & 5.13 & 68.09 \\
\hline
\end{tabular}


Table A.2 Experimental Data from Experiments 3.1 - 3.3.

\begin{tabular}{|c|c|c|c|c|c|}
\hline \multirow{2}{*}{\multicolumn{3}{|c|}{$\begin{array}{c}\text { Exp. } 3.1 \\
\text { Sieved with Supernate }\end{array}$}} & \multirow{2}{*}{\multicolumn{2}{|c|}{$\begin{array}{l}\text { otal Sample Used }(\mathrm{g})= \\
\text { Insoluble Solids }(\mathrm{g})=\end{array}$}} & \multirow{2}{*}{$\begin{array}{l}5.0433 \\
0.5926\end{array}$} \\
\hline & & & & & \\
\hline $\begin{array}{l}\text { Sieve Size } \\
\text { (microns or } \\
\text { mesh) }\end{array}$ & $\begin{array}{l}\text { Dry Wt of } \\
\text { Sieve }(\mathrm{g})\end{array}$ & $\begin{array}{c}\text { Wt. After } \\
\text { Sieving Slurry } \\
\text { and Drying (g) }\end{array}$ & $\begin{array}{c}\text { Dry Wt of } \\
\text { Sieve }(\mathrm{g})-\mathrm{Wt} . \\
\text { After Sieving } \\
\text { Slurry and } \\
\text { Drying }(\mathrm{g})\end{array}$ & $\begin{array}{c}\text { \% of Insoluble } \\
\text { Solids } \\
\text { Collected on } \\
\text { Sieve }\end{array}$ & $\begin{array}{c}\text { \% of Solids } \\
\text { Below Sieve } \\
\text { Size }\end{array}$ \\
\hline 38 & 80.5605 & 80.7081 & 0.1476 & 24.91 & 75.09 \\
\hline 32 & 80.5823 & 80.6477 & 0.0654 & 11.04 & 64.06 \\
\hline 25 & 80.5381 & 80.6054 & 0.0673 & 11.36 & 52.70 \\
\hline 20 & 73.4327 & 73.51 & 0.0773 & 13.04 & 39.65 \\
\hline $\begin{array}{c}16-18 \\
(165 \times 1400)\end{array}$ & 84.3837 & 84.4291 & 0.0454 & 7.66 & 31.99 \\
\hline $\begin{array}{c}12-14 \\
(200 \times 1400)\end{array}$ & 75.422 & 75.5317 & 0.1097 & 18.51 & 13.48 \\
\hline $\begin{array}{c}11-12 \\
(250 \times 1400)\end{array}$ & 75.5882 & 75.6403 & 0.0521 & 8.79 & 4.69 \\
\hline $\begin{array}{c}8-9 \\
(325 \times 2300) \\
(3)\end{array}$ & 75.6283 & 75.9945 & 0.3662 & 61.80 & -57.11 \\
\hline $\begin{array}{c}5-6 \\
(510 \times 3600)\end{array}$ & 80.732 & 81.1475 & 0.4155 & 70.12 & -127.22 \\
\hline \multirow{2}{*}{\multicolumn{3}{|c|}{$\begin{array}{c}\text { Exp. } \mathbf{3 . 2} \\
\text { Sieved with Supernate }\end{array}$}} & \multicolumn{2}{|c|}{ otal Sample Used $(\mathrm{g})=$} & 5.0454 \\
\hline & & & \multicolumn{2}{|c|}{ Insoluble Solids $(\mathrm{g})=$} & 0.5928 \\
\hline $\begin{array}{c}\text { Sieve Size } \\
\text { (microns or } \\
\text { mesh) }\end{array}$ & $\begin{array}{l}\text { Dry Wt of } \\
\text { Sieve }(g)\end{array}$ & $\begin{array}{c}\text { Wt. After } \\
\text { Sieving Slurry } \\
\text { and Drying (g) }\end{array}$ & $\begin{array}{c}\text { Dry Wt of } \\
\text { Sieve }(\mathrm{g})-\mathrm{Wt} . \\
\text { After Sieving } \\
\text { Slurry and } \\
\text { Drying }(\mathrm{g})\end{array}$ & $\begin{array}{l}\text { \% of Insoluble } \\
\text { Solids } \\
\text { Collected on } \\
\text { Sieve }\end{array}$ & $\begin{array}{c}\text { \% of Solids } \\
\text { Below Sieve } \\
\text { Size }\end{array}$ \\
\hline 38 & 80.0745 & 80.1906 & 0.1161 & 19.58 & 80.42 \\
\hline 32 & 81.1278 & 81.1375 & 0.0097 & 1.64 & 78.78 \\
\hline 25 & 72.9554 & 72.9576 & 0.0022 & 0.37 & 78.41 \\
\hline & & & \multicolumn{2}{|c|}{$\begin{array}{c}\text { Insoluble Solids } \\
(\mathrm{g})=\end{array}$} & $\begin{array}{l}1.0427 \\
0.1225\end{array}$ \\
\hline 20 & 71.8797 & 71.8861 & 0.0064 & 5.22 & 73.19 \\
\hline $\begin{array}{c}16-18 \\
(165 \times 1400)\end{array}$ & 83.6655 & 83.6827 & 0.0172 & 14.04 & 59.15 \\
\hline $\begin{array}{c}12-14 \\
(200 \times 1400)\end{array}$ & 84.7724 & 84.7766 & 0.0042 & 3.43 & 55.72 \\
\hline \multicolumn{5}{|c|}{$\begin{array}{l}\text { Total Sample Used }(\mathrm{g})= \\
\text { Insoluble Solids }\end{array}$} & $\begin{array}{l}0.5198 \\
0.0611\end{array}$ \\
\hline $\begin{array}{c}11-12 \\
(250 \times 1400) \\
\end{array}$ & 81.8233 & 81.8378 & 0.0145 & 23.74 & 31.98 \\
\hline $\begin{array}{c}8-9 \\
(325 \times 2300) \\
\end{array}$ & 73.7102 & 73.7251 & 0.0149 & 24.40 & 7.58 \\
\hline $\begin{array}{c}5-6 \\
(510 \times 3600) \\
\end{array}$ & 80.8067 & 80.8165 & 0.0098 & 16.05 & -8.46 \\
\hline
\end{tabular}


WSRC-TR-2005-00077

Revision 0

Table A.2 Continued. Experimental Data from Experiments 3.1 - 3.3.

\begin{tabular}{|c|c|c|c|c|c|}
\hline \multirow{2}{*}{\multicolumn{3}{|c|}{$\begin{array}{c}\text { Exp. } \mathbf{3 . 3} \\
\text { Sieved with Supernate }\end{array}$}} & \multirow{2}{*}{\multicolumn{2}{|c|}{$\begin{array}{l}\text { otal Sample Used }(\mathrm{g})= \\
\text { Insoluble Solids }(\mathrm{g})=\end{array}$}} & \multirow{2}{*}{$\begin{array}{l}5.1435 \\
0.6044\end{array}$} \\
\hline & & & & & \\
\hline $\begin{array}{l}\text { Sieve Size } \\
\text { (microns or } \\
\text { mesh) }\end{array}$ & $\begin{array}{l}\text { Dry Wt of } \\
\text { Sieve }(g)\end{array}$ & $\begin{array}{c}\text { Wt. After } \\
\text { Sieving Slurry } \\
\text { and Drying (g) }\end{array}$ & $\begin{array}{c}\text { Dry Wt of } \\
\text { Sieve (g) - Wt. } \\
\text { After Sieving } \\
\text { Slurry and } \\
\text { Drying (g) }\end{array}$ & $\begin{array}{c}\% \text { of Insoluble } \\
\text { Solids } \\
\text { Collected on } \\
\text { Sieve }\end{array}$ & $\begin{array}{c}\text { \% of Solids } \\
\text { Below Sieve } \\
\text { Size }\end{array}$ \\
\hline 38 & 80.4293 & 80.558 & 0.1287 & 21.30 & 78.70 \\
\hline 32 & 80.4921 & 80.5135 & 0.0214 & 3.54 & 75.16 \\
\hline 25 & 80.4471 & 80.4625 & 0.0154 & 2.55 & 72.62 \\
\hline \multicolumn{5}{|c|}{$\begin{array}{c}\text { Total Sample Used }(\mathrm{g})= \\
\text { Insoluble Solids }(\mathrm{g})=\end{array}$} & $\begin{array}{l}1.3053 \\
0.1534\end{array}$ \\
\hline 20 & 71.3248 & 71.362 & -0.0048 & 0.00 & 72.62 \\
\hline $\begin{array}{c}16-18 \\
(165 \times 1400)\end{array}$ & 75.0208 & 75.0355 & 0.0147 & 9.58 & 63.03 \\
\hline $\begin{array}{c}12-14 \\
(200 \times 1400)\end{array}$ & 83.6747 & 83.6952 & 0.0205 & 13.37 & 49.67 \\
\hline \multicolumn{5}{|c|}{$\begin{array}{l}\text { Total Sample Used }(g)= \\
\text { Insoluble Solids }(g)=\end{array}$} & $\begin{array}{l}0.5694 \\
0.0669\end{array}$ \\
\hline $\begin{array}{c}11-12 \\
(250 \times 1400)\end{array}$ & 81.1583 & 81.1966 & 0.0013 & 1.93 & 47.74 \\
\hline $\begin{array}{c}8-9 \\
(325 \times 2300) \\
\end{array}$ & 73.608 & 73.6085 & 0.0005 & 0.75 & 46.99 \\
\hline $\begin{array}{c}5-6 \\
(510 \times 3600) \\
\end{array}$ & 80.7602 & 80.7665 & 0.0063 & 9.42 & 37.57 \\
\hline
\end{tabular}


WSRC-TR-2005-00077

Revision 0

Table A.3 Experimental Data from Experiments 4.1 - 4.2.

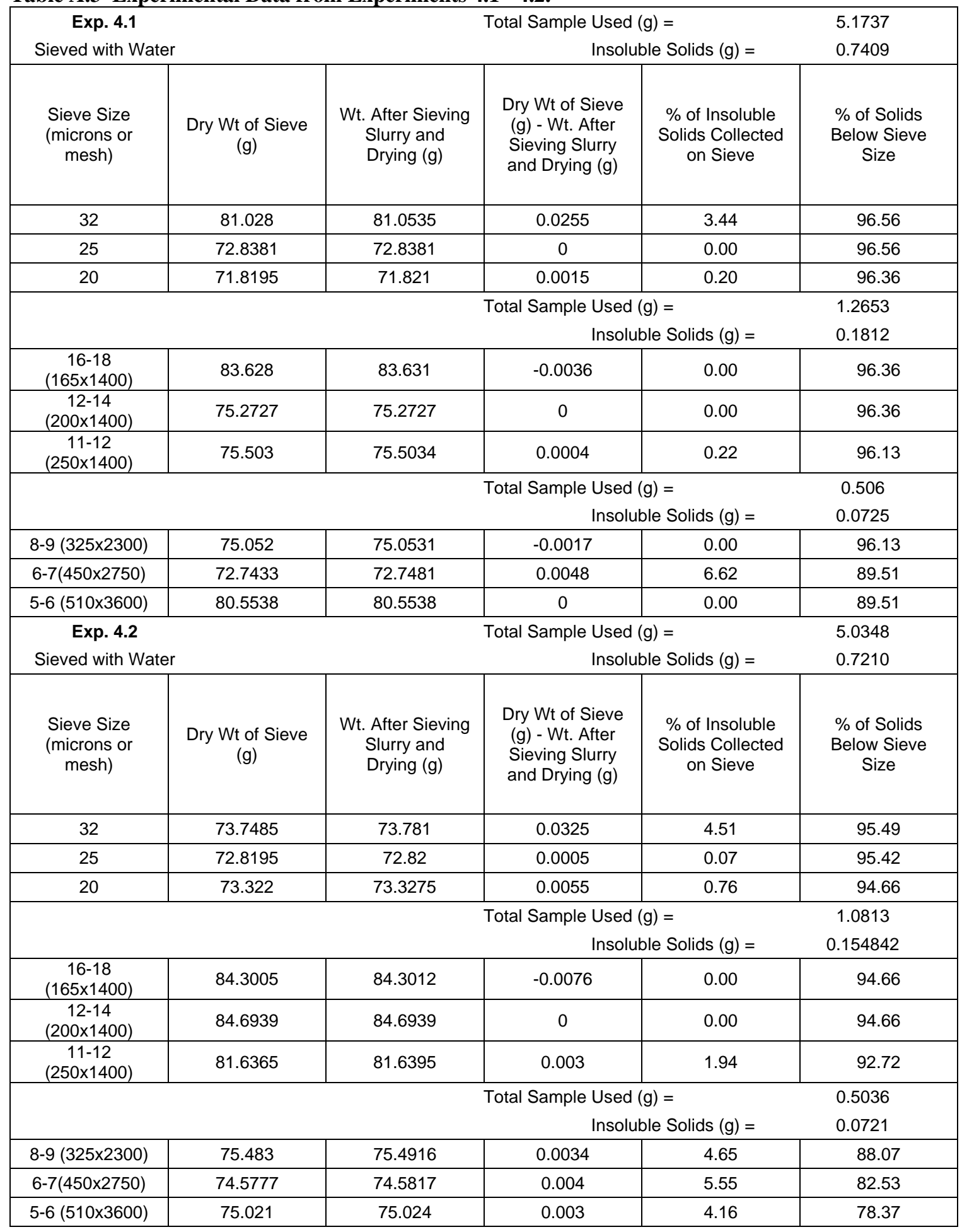


WSRC-TR-2005-00077

Revision 0

Table A.4 Experimental Data from Experiments 5.1 - 5.2.

\begin{tabular}{|c|c|c|c|c|c|}
\hline \multirow{2}{*}{\multicolumn{2}{|c|}{$\begin{array}{c}\text { Exp. } \mathbf{5 . 1} \\
\text { Sieved with Supernate }\end{array}$}} & \multicolumn{3}{|c|}{ Total Sample Used $(\mathrm{g})=$} & 5.0368 \\
\hline & & \multicolumn{2}{|c|}{ Insoluble Solids $(\mathrm{g})=$} & \multicolumn{2}{|c|}{0.7213} \\
\hline $\begin{array}{l}\text { Sieve Size } \\
\text { (microns or } \\
\text { mesh) }\end{array}$ & $\begin{array}{l}\text { Dry Wt of Sieve } \\
\text { (g) }\end{array}$ & $\begin{array}{l}\text { Wt. After Sieving } \\
\text { Slurry and } \\
\text { Drying (g) }\end{array}$ & $\begin{array}{l}\text { Dry Wt of Sieve } \\
\text { (g) - Wt. After } \\
\text { Sieving Slurry } \\
\text { and Drying (g) }\end{array}$ & $\begin{array}{l}\% \text { of Insoluble } \\
\text { Solids Collected } \\
\text { on Sieve }\end{array}$ & $\begin{array}{c}\% \text { of Solids } \\
\text { Below Sieve } \\
\text { Size }\end{array}$ \\
\hline 32 & 80.4422 & 80.489 & 0.0468 & 6.49 & 93.51 \\
\hline 25 & 72.7478 & 72.7555 & 0.0077 & 1.07 & 92.44 \\
\hline 20 & 73.2633 & 73.2754 & 0.0121 & 1.68 & 90.77 \\
\hline \multicolumn{5}{|c|}{ Total Sample Used $(\mathrm{g})=$} & $\begin{array}{r}1.0938 \\
0.1566\end{array}$ \\
\hline $\begin{array}{c}16-18 \\
(165 \times 1400)\end{array}$ & 84.271 & 84.2915 & 0.006037031 & 3.85 & 86.91 \\
\hline $\begin{array}{c}12-14 \\
(200 \times 1400)\end{array}$ & 75.26 & 75.2705 & 0.0105 & 6.70 & 80.21 \\
\hline $\begin{array}{c}11-12 \\
(250 \times 1400)\end{array}$ & 81.1215 & 81.139 & 0.0175 & 11.17 & 69.04 \\
\hline \multicolumn{5}{|c|}{ Total Sample Used $(\mathrm{g})=$} & 0.5879 \\
\hline \multicolumn{5}{|c|}{ Insoluble Solids $(\mathrm{g})=$} & 0.0842 \\
\hline $8-9(325 \times 2300)$ & 74.9575 & 74.9667 & -0.016867974 & 0.00 & 69.04 \\
\hline $6-7(450 \times 2750)$ & 74.7879 & 74.7963 & 0.0084 & 9.98 & 59.06 \\
\hline $5-6(510 \times 3600)$ & 80.5448 & 80.5546 & 0.0098 & 11.64 & 47.42 \\
\hline \multicolumn{2}{|c|}{ Exp. 5.2} & \multicolumn{3}{|c|}{ Total Sample Used $(\mathrm{g})=$} & 5.0799 \\
\hline \multicolumn{2}{|c|}{ Sieved with Supernate } & \multicolumn{2}{|c|}{ Insoluble Solids $(\mathrm{g})=$} & \multicolumn{2}{|c|}{0.7274} \\
\hline $\begin{array}{l}\text { Sieve Size } \\
\text { (microns or } \\
\text { mesh) }\end{array}$ & $\begin{array}{c}\text { Dry Wt of Sieve } \\
(\mathrm{g})\end{array}$ & $\begin{array}{l}\text { Wt. After Sieving } \\
\text { Slurry and } \\
\text { Drying (g) }\end{array}$ & $\begin{array}{l}\text { Dry Wt of Sieve } \\
\text { (g) - Wt. After } \\
\text { Sieving Slurry } \\
\text { and Drying (g) }\end{array}$ & $\begin{array}{l}\% \text { of Insoluble } \\
\text { Solids Collected } \\
\text { on Sieve }\end{array}$ & $\begin{array}{l}\% \text { of Solids } \\
\text { Below Sieve } \\
\text { Size }\end{array}$ \\
\hline 32 & 81.0065 & 81.0568 & 0.0503 & 6.91 & 93.09 \\
\hline 25 & 80.4064 & 80.4173 & 0.0109 & 1.50 & 91.59 \\
\hline 20 & 71.2716 & 71.2788 & 0.0072 & 0.99 & 90.60 \\
\hline \multicolumn{5}{|c|}{ Total Sample Used $(\mathrm{g})=$} & 1.1443 \\
\hline & & & \multicolumn{2}{|c|}{ Insoluble Solids $(\mathrm{g})=$} & 0.1639 \\
\hline $\begin{array}{c}16-18 \\
(165 \times 1400)\end{array}$ & 74.9406 & 74.963 & 0.006992193 & 4.27 & 86.33 \\
\hline $\begin{array}{c}12-14 \\
(200 \times 1400) \\
\end{array}$ & 83.622 & 83.6346 & 0.0126 & 7.69 & 78.64 \\
\hline \multirow[t]{3}{*}{$\begin{array}{c}11-12 \\
(250 \times 1400) \\
\end{array}$} & 75.4684 & 75.488 & 0.0196 & 11.96 & 66.68 \\
\hline & & & \multicolumn{2}{|c|}{ Total Sample Used $(\mathrm{g})=$} & 0.5705 \\
\hline & & & \multicolumn{2}{|c|}{ Insoluble Solids $(\mathrm{g})=$} & 0.081 \\
\hline $8-9(325 \times 2300)$ & 73.5325 & 73.5501 & 0 & 0.00 & 66.68 \\
\hline $6-7(450 \times 2750)$ & 72.7239 & 72.733 & 0.0091 & 11.14 & 55.54 \\
\hline $5-6(510 \times 3600)$ & 80.5343 & 80.5405 & 0.0062 & 7.59 & 47.95 \\
\hline
\end{tabular}


WSRC-TR-2005-00077

Revision 0

Table A.5 Experimental Data from Experiments 6.1 - 6.2.

\begin{tabular}{|c|c|c|c|c|c|}
\hline \multirow{2}{*}{\multicolumn{3}{|c|}{$\begin{array}{c}\text { Exp. } \mathbf{6 . 1} \\
\text { Sieved with Water }\end{array}$}} & \multirow{2}{*}{\multicolumn{2}{|c|}{$\begin{array}{c}\text { Total Sample Used }(\mathrm{g})= \\
\text { Insoluble Solids }(\mathrm{g})=\end{array}$}} & \multirow{2}{*}{$\begin{array}{c}10.3127 \\
1.8614\end{array}$} \\
\hline & & & & & \\
\hline $\begin{array}{l}\text { Sieve Size } \\
\text { (microns or } \\
\text { mesh) }\end{array}$ & $\begin{array}{l}\text { Dry Wt of Sieve } \\
\text { (g) }\end{array}$ & $\begin{array}{l}\text { Wt. After Sieving } \\
\text { Slurry and } \\
\text { Drying (g) }\end{array}$ & $\begin{array}{l}\text { Dry Wt of Sieve } \\
\text { (g) - Wt. After } \\
\text { Sieving Slurry } \\
\text { and Drying (g) }\end{array}$ & $\begin{array}{l}\% \text { of Insoluble } \\
\text { Solids Collected } \\
\text { on Sieve }\end{array}$ & $\begin{array}{l}\% \text { of Solids } \\
\text { Below Sieve } \\
\text { Size }\end{array}$ \\
\hline 150 & 73.3513 & 73.3994 & 0.0481 & 2.58 & 97.42 \\
\hline 75 & 80.0686 & 80.2415 & 0.1729 & 9.29 & 88.13 \\
\hline 45 & 80.3802 & 80.581 & 0.2008 & 10.79 & 77.34 \\
\hline \multicolumn{5}{|c|}{ Total Sample Used $(\mathrm{g})=$} & 5.4166 \\
\hline & & & \multicolumn{2}{|c|}{ Insoluble Solids $(\mathrm{g})=$} & 0.9777 \\
\hline 32 & 81.0435 & 81.3794 & 0.1144 & 11.70 & 65.64 \\
\hline 25 & 72.8489 & 72.8947 & 0.0458 & 4.68 & 60.96 \\
\hline & & & \multicolumn{2}{|c|}{ Total Sample Used $(\mathrm{g})=$} & 0.5977 \\
\hline & & & \multicolumn{2}{|c|}{ Insoluble Solids $(\mathrm{g})=$} & 0.1079 \\
\hline $\begin{array}{c}16-18 \\
(165 \times 1400)\end{array}$ & 84.298 & 84.347 & 0.0069 & 6.38 & 54.58 \\
\hline $\begin{array}{c}12-14 \\
(200 \times 1400) \\
\end{array}$ & 84.7025 & 84.7089 & 0.0064 & 5.93 & 48.65 \\
\hline $\begin{array}{c}11-12 \\
(250 \times 1400) \\
\end{array}$ & 75.5133 & 75.5203 & 0.007 & 6.49 & 42.16 \\
\hline & & & \multirow{2}{*}{\multicolumn{2}{|c|}{$\begin{array}{l}\text { Total Sample Used }(\mathrm{g})= \\
\text { Insoluble Solids }(\mathrm{g})=\end{array}$}} & 0.5404 \\
\hline & & & & & 0.0975 \\
\hline $8-9(325 \times 2300)$ & 75.5048 & 75.5675 & 0.0035 & 3.63 & 38.53 \\
\hline $6-7(450 \times 2750)$ & 74.7202 & 74.7218 & 0.0016 & 1.64 & 36.89 \\
\hline $5-6(510 \times 3600)$ & 80.585 & 80.5865 & 0.0015 & 1.54 & 35.36 \\
\hline \multicolumn{3}{|c|}{ Exp. 6.2} & \multicolumn{2}{|c|}{ Total Sample Used $(\mathrm{g})=$} & 10.2919 \\
\hline \multicolumn{3}{|c|}{ Sieved with Water } & \multicolumn{2}{|c|}{ Insoluble Solids $(\mathrm{g})=$} & 1.8577 \\
\hline $\begin{array}{l}\text { Sieve Size } \\
\text { (microns or } \\
\text { mesh) }\end{array}$ & $\begin{array}{l}\text { Dry Wt of Sieve } \\
\text { (g) }\end{array}$ & $\begin{array}{l}\text { Wt. After Sieving } \\
\text { Slurry and } \\
\text { Drying }(\mathrm{g})\end{array}$ & $\begin{array}{l}\text { Dry Wt of Sieve } \\
\text { (g) - Wt. After } \\
\text { Sieving Slurry } \\
\text { and Drying (g) }\end{array}$ & $\begin{array}{l}\% \text { of Insoluble } \\
\text { Solids Collected } \\
\text { on Sieve }\end{array}$ & $\begin{array}{l}\% \text { of Solids } \\
\text { Below Sieve } \\
\text { Size }\end{array}$ \\
\hline 150 & 74.3015 & 74.3391 & 0.0376 & 2.02 & 97.98 \\
\hline 75 & 74.0275 & 74.2031 & 0.1756 & 9.45 & 88.52 \\
\hline 45 & 75.0689 & 75.2855 & 0.2166 & 11.66 & 76.86 \\
\hline & & & \multicolumn{2}{|c|}{ Total Sample Used $(\mathrm{g})=$} & 5.6663 \\
\hline & & & \multicolumn{2}{|c|}{ Insoluble Solids $(\mathrm{g})=$} & 1.0228 \\
\hline 32 & 73.7805 & 74.1222 & 0.1051 & 10.27 & 66.59 \\
\hline 25 & 72.8969 & 72.9403 & 0.0434 & 4.24 & 62.35 \\
\hline & & & \multirow{2}{*}{\multicolumn{2}{|c|}{ Total Sample Used $(\mathrm{g})=$}} & 0.6108 \\
\hline & & & & Insoluble Solids $(\mathrm{g})=$ & 0.1102 \\
\hline $\begin{array}{c}16-18 \\
(165 \times 1400)\end{array}$ & 83.644 & 83.7 & 0.0145 & 13.14 & 49.21 \\
\hline $\begin{array}{c}12-14 \\
(200 \times 1400)\end{array}$ & 75.2882 & 75.2982 & 0.01 & 9.07 & 40.14 \\
\hline \multirow[t]{3}{*}{$\begin{array}{c}11-12 \\
(250 \times 1400) \\
\end{array}$} & 81.6427 & 81.6515 & 0.0088 & 7.98 & 32.15 \\
\hline & & & \multicolumn{2}{|c|}{ Total Sample Used $(\mathrm{g})=$} & 0.5622 \\
\hline & & & \multicolumn{2}{|c|}{ Insoluble Solids $(\mathrm{g})=$} & 0.1015 \\
\hline $8-9(325 \times 2300)$ & 75.0734 & 75.1394 & 0.0045 & 4.48 & 27.68 \\
\hline $6-7(450 \times 2750)$ & 72.8665 & 72.87 & 0.0035 & 3.45 & 24.23 \\
\hline $5-6(510 \times 3600)$ & 75.1047 & 75.1049 & 0.0002 & 0.20 & 24.03 \\
\hline
\end{tabular}


WSRC-TR-2005-00077

Revision 0

Table A.6 Experimental data from Experiments 7.1-7.2.

\begin{tabular}{|c|c|c|c|c|c|}
\hline \multirow{2}{*}{\multicolumn{3}{|c|}{$\begin{array}{c}\text { Exp. } 7.1 \\
\text { Sieved with Supernate }\end{array}$}} & \multirow{2}{*}{\multicolumn{2}{|c|}{$\begin{array}{l}\text { Total Sample Used }(\mathrm{g})= \\
\text { Insoluble Solids }(\mathrm{g})=\end{array}$}} & \multirow{2}{*}{$\begin{array}{l}4.9980 \\
0.9021\end{array}$} \\
\hline & & & & & \\
\hline $\begin{array}{l}\text { Sieve Size } \\
\text { (microns or } \\
\text { mesh) }\end{array}$ & $\begin{array}{l}\text { Dry Wt of Sieve } \\
(\mathrm{g})\end{array}$ & $\begin{array}{l}\text { Wt. After Sieving } \\
\text { Slurry and } \\
\text { Drying (g) }\end{array}$ & $\begin{array}{l}\text { Dry Wt of Sieve } \\
\text { (g) - Wt. After } \\
\text { Sieving Slurry } \\
\text { and Drying (g) }\end{array}$ & $\begin{array}{l}\% \text { of Insoluble } \\
\text { Solids Collected } \\
\text { on Sieve }\end{array}$ & $\begin{array}{c}\% \text { of Solids } \\
\text { Below Sieve } \\
\text { Size }\end{array}$ \\
\hline 150 & 73.3006 & 73.34444 & 0.04384 & 4.86 & 95.14 \\
\hline 75 & 80.0242 & 80.1635 & 0.1393 & 15.44 & 79.70 \\
\hline 45 & 80.3355 & 80.455 & 0.1195 & 13.25 & 66.45 \\
\hline \multicolumn{5}{|c|}{ Total Sample Used $(\mathrm{g})=$} & 1.0012 \\
\hline \multicolumn{5}{|c|}{ Insoluble Solids $(\mathrm{g})=$} & 0.1807 \\
\hline 32 & 73.7058 & 73.7777 & 0.0113 & 6.24 & 60.21 \\
\hline 25 & 72.7662 & 72.786 & 0.0198 & 10.96 & 49.26 \\
\hline \multirow{2}{*}{\multicolumn{5}{|c|}{$\begin{array}{l}\text { Total Sample Used } \\
(\mathrm{g})= \\
\text { Insoluble Solids }(\mathrm{g})=\end{array}$}} & 0.5557 \\
\hline & & & & & 0.1003 \\
\hline $16-18(165 \times 1400)$ & 83.5363 & 83.5945 & 0.0073 & 7.28 & 41.98 \\
\hline $12-14(200 \times 1400)$ & 84.6671 & 84.7014 & 0.0343 & 34.20 & 7.78 \\
\hline $11-12(250 \times 1400)$ & 81.6089 & 81.6313 & 0.0224 & 22.33 & -14.55 \\
\hline \multicolumn{5}{|c|}{ Total Sample Used $(\mathrm{g})=$} & 0.5217 \\
\hline \multicolumn{5}{|c|}{ Insoluble Solids $(\mathrm{g})=$} & 0.0942 \\
\hline $8-9(325 \times 2300)$ & 75.0086 & 75.0139 & 0.0006 & 0.61 & -15.16 \\
\hline $6-7(450 \times 2750)$ & 74.849 & 74.8551 & 0.0061 & 6.48 & -21.64 \\
\hline $5-6(510 \times 3600)$ & 74.8719 & 74.8881 & 0.0162 & 17.20 & -38.84 \\
\hline Exp. 7.2 & & & otal Sample Used & & 5.0318 \\
\hline \multicolumn{3}{|c|}{ Sieved with Supernate } & \multicolumn{2}{|c|}{ Insoluble Solids $(\mathrm{g})=$} & 0.9082 \\
\hline $\begin{array}{l}\text { Sieve Size } \\
\text { (microns or } \\
\text { mesh) }\end{array}$ & $\begin{array}{l}\text { Dry Wt of Sieve } \\
(\mathrm{g})\end{array}$ & $\begin{array}{l}\text { Wt. After Sieving } \\
\text { Slurry and } \\
\text { Drying (g) }\end{array}$ & $\begin{array}{l}\text { Dry Wt of Sieve } \\
\text { (g) - Wt. After } \\
\text { Sieving Slurry } \\
\text { and Drying (g) }\end{array}$ & $\begin{array}{l}\% \text { of Insoluble } \\
\text { Solids Collected } \\
\text { on Sieve }\end{array}$ & $\begin{array}{c}\% \text { of Solids } \\
\text { Below Sieve } \\
\text { Size }\end{array}$ \\
\hline 150 & 73.2305 & 73.2585 & 0.028 & 3.08 & 96.92 \\
\hline 75 & 79.951 & 80.0445 & 0.0935 & 10.29 & 86.62 \\
\hline 45 & 80.2665 & 80.3943 & 0.1278 & 14.07 & 72.55 \\
\hline \multicolumn{5}{|c|}{ Total Sample Used $(\mathrm{g})=$} & 1.0932 \\
\hline \multicolumn{5}{|c|}{ Insoluble Solids $(\mathrm{g})=$} & 0.1973 \\
\hline 32 & 80.3525 & 80.4358 & 0.0291 & 14.77 & 57.78 \\
\hline 25 & 72.6565 & 72.6635 & 0.007 & 3.55 & 54.24 \\
\hline \multicolumn{5}{|c|}{ Total Sample Used $(\mathrm{g})=$} & 0.5380 \\
\hline \multicolumn{5}{|c|}{ Insoluble Solids $(\mathrm{g})=$} & 0.0971 \\
\hline $16-18(165 \times 1400)$ & 74.8935 & 74.9478 & 0.0099 & 10.15 & 44.08 \\
\hline $12-14(200 \times 1400)$ & 75.228 & 75.238 & 0.01 & 10.30 & 33.79 \\
\hline $11-12(250 \times 1400)$ & 75.4313 & 75.4518 & 0.0205 & 21.11 & 12.68 \\
\hline \multicolumn{5}{|c|}{ Total Sample Used $(\mathrm{g})=$} & 0.5744 \\
\hline \multicolumn{5}{|c|}{ Insoluble Solids $(\mathrm{g})=$} & 0.1037 \\
\hline $8-9(325 \times 2300)$ & 75.2831 & 75.349 & 0.0060 & 5.75 & 6.92 \\
\hline $6-7(450 \times 2750)$ & 72.6199 & 72.626 & 0.0061 & 5.88 & 1.04 \\
\hline $5-6(510 \times 3600)$ & 80.51 & 80.522 & 0.012 & 11.57 & -10.54 \\
\hline
\end{tabular}


WSRC-TR-2005-00077

Revision 0

This page intentionally left blank. 
Revision 0

\section{APPENDIX B}

Data tables for Experiments 3.4, 5.3, and 7.3 
WSRC-TR-2005-00077

Revision 0

Table B.1 Experimental data from Experiment 3.4 - Sieving of supernate only to obtain dissolved solids correction factor.

\begin{tabular}{|c|c|c|c|}
\hline $\begin{array}{c}\text { Exp. } 1 \\
\text { (Sieve Size) }\end{array}$ & Dry Wt of Sieve (g) & $\begin{array}{l}\text { Wt. After Sieving } \\
\text { Supernate and Drying } \\
\text { (g) }\end{array}$ & $\begin{array}{c}\text { Dissolved Solids } \\
\text { Correction Factor (Dry } \\
\text { Wt of Sieve }(\mathrm{g}) \text { - Wt. } \\
\text { After Sieving Supernate } \\
\text { and Drying }(\mathrm{g})\end{array}$ \\
\hline 38 & 79.9695 & 79.9833 & 0.0138 \\
\hline 32 & 80.9752 & 80.9875 & 0.0123 \\
\hline 25 & 80.3718 & 80.3868 & 0.015 \\
\hline 20 & 71.2203 & 71.2321 & 0.0118 \\
\hline $16-18(165 \times 1400)$ & 84.2383 & 84.2685 & 0.0302 \\
\hline $12-14(200 \times 1400)$ & 83.599 & 83.6235 & 0.0245 \\
\hline $11-12(250 \times 1400)$ & 81.1 & 81.1566 & 0.0566 \\
\hline $8-9(325 \times 2300)$ & 73.4505 & 73.4712 & 0.0207 \\
\hline $5-6(510 \times 3600)$ & 74.8134 & 74.8342 & 0.0208 \\
\hline $\begin{array}{c}\text { Exp. } 2 \\
\text { (Sieve Size) }\end{array}$ & Dry Wt of Sieve (g) & $\begin{array}{l}\text { Wt. After Sieving } \\
\text { Supernate and Drying } \\
\text { (g) }\end{array}$ & $\begin{array}{c}\text { Dissolved Solids } \\
\text { Correction Factor (Dry } \\
\text { Wt of Sieve (g) - Wt. } \\
\text { After Sieving Supernate } \\
\text { and Drying (g) }\end{array}$ \\
\hline 38 & 80.3783 & 80.3878 & 0.0095 \\
\hline 32 & 73.6687 & 73.6807 & 0.012 \\
\hline 25 & 72.7271 & 72.7418 & 0.0147 \\
\hline 20 & 73.2064 & 73.2221 & 0.0157 \\
\hline $16-18(165 \times 1400)$ & 74.8781 & 74.9093 & 0.0312 \\
\hline $12-14(200 \times 1400)$ & 75.2211 & 75.2463 & 0.0252 \\
\hline $11-12(250 \times 1400)$ & 75.4064 & 75.4598 & 0.0534 \\
\hline $8-9(325 \times 2300)$ & 75.2612 & 75.2833 & 0.0221 \\
\hline $5-6(510 \times 3600)$ & 80.4926 & 80.5192 & 0.0266 \\
\hline (Sieve Size) & $\begin{array}{c}\text { Average } \\
\text { Dissolved Solids } \\
\text { on Each Sieve } \\
\text { From Two } \\
\text { Experiments (g) }\end{array}$ & $\begin{array}{l}\text { Standard } \\
\text { Deviation }\end{array}$ & $\%$ RSD \\
\hline 38 & 0.0117 & 0.0030 & 26.0992 \\
\hline 32 & 0.0121 & 0.0002 & 1.7459 \\
\hline 25 & 0.0149 & 0.0002 & 1.4285 \\
\hline 20 & 0.0138 & 0.0028 & 20.0561 \\
\hline $16-18(165 \times 1400)$ & 0.0307 & 0.0007 & 2.3033 \\
\hline $12-14(200 \times 1400)$ & 0.0249 & 0.0005 & 1.9919 \\
\hline $11-12(250 \times 1400)$ & 0.0550 & 0.0023 & 4.1141 \\
\hline $8-9(325 \times 2300)$ & 0.0214 & 0.0010 & 4.6259 \\
\hline $5-6(510 \times 3600)$ & 0.0237 & 0.0041 & 17.3047 \\
\hline
\end{tabular}


Table B.2 Dissolved solids corrected data from Experiments 3.1-3.3 using values from Table A.2. The plot in Figure 3.7 (Exp. 3.4) is the average concentration from Experiments 3.2 and 3.3.

\begin{tabular}{|c|c|c|c|c|c|c|c|}
\hline \multirow{2}{*}{\multicolumn{4}{|c|}{$\begin{array}{c}\text { Exp.1 } \\
\text { Sieved with Supernate }\end{array}$}} & \multirow{2}{*}{\multicolumn{2}{|c|}{$\begin{array}{l}\text { Total Sample Used }(\mathrm{g})= \\
\text { Insoluble Solids }(\mathrm{g})=\end{array}$}} & \multirow{2}{*}{\multicolumn{2}{|c|}{$\begin{array}{l}5.0433 \\
0.5926 \\
\end{array}$}} \\
\hline & & & & & & & \\
\hline $\begin{array}{l}\text { Sieve Size } \\
\text { (microns or } \\
\text { mesh) }\end{array}$ & $\begin{array}{l}\text { Dry Wt of } \\
\text { Sieve }(g)\end{array}$ & $\begin{array}{l}\text { Wt. After } \\
\text { Sieving } \\
\text { Slurry and } \\
\text { Drying (g) }\end{array}$ & $\begin{array}{l}\text { Dry Wt of } \\
\text { Sieve (g) - } \\
\text { Wt. After } \\
\text { Sieving } \\
\text { Slurry and } \\
\text { Drying (g) }\end{array}$ & $\begin{array}{c}\text { Dissolved } \\
\text { Solids }(\mathrm{g})- \\
\text { From Table } \\
\text { B.1 }\end{array}$ & $\begin{array}{c}\text { Delta- } \\
\text { Dissolved } \\
\text { Solids (g) or } \\
\text { Corrected } \\
\text { Mass of } \\
\text { Solids on } \\
\text { Sieve (g) }\end{array}$ & $\begin{array}{c}\% \text { of } \\
\text { Insoluble } \\
\text { Solids } \\
\text { Collected } \\
\text { on Sieve }\end{array}$ & $\begin{array}{l}\text { \% of Solids } \\
\text { Below Sieve } \\
\text { Size }\end{array}$ \\
\hline 38 & 80.5605 & 80.7081 & 0.1476 & 0.01165 & 0.1359 & 22.94 & 77.06 \\
\hline 32 & 80.5823 & 80.6477 & 0.0654 & 0.01215 & 0.0532 & 8.99 & 68.07 \\
\hline 25 & 80.5381 & 80.6054 & 0.0673 & 0.01485 & 0.0525 & 8.85 & 59.22 \\
\hline 20 & 73.4327 & 73.51 & 0.0773 & 0.01375 & 0.0636 & 10.72 & 48.50 \\
\hline $\begin{array}{c}16-18 \\
(165 \times 1400)\end{array}$ & 84.3837 & 84.4291 & 0.0454 & 0.0307 & 0.0147 & 2.48 & 46.02 \\
\hline $\begin{array}{c}12-14 \\
(200 \times 1400) \\
\end{array}$ & 75.422 & 75.5317 & 0.1097 & 0.02485 & 0.0849 & 14.32 & 31.70 \\
\hline $\begin{array}{c}11-12 \\
(250 \times 1400) \\
\end{array}$ & 75.5882 & 75.6403 & 0.0521 & 0.055 & 0.0000 & 0.00 & 31.70 \\
\hline $\begin{array}{c}8-9 \\
(325 \times 2300)\end{array}$ & 75.6283 & 75.9945 & 0.3662 & 0.0214 & 0.3448 & 58.19 & -26.49 \\
\hline $\begin{array}{c}5-6 \\
(510 \times 3600) \\
\end{array}$ & 80.732 & 81.1475 & 0.4155 & 0.0237 & 0.3918 & 66.12 & -92.60 \\
\hline \multicolumn{3}{|c|}{ Exp.2 } & \multicolumn{4}{|c|}{ Total Sample Used $(\mathrm{g})=$} & 5.0454 \\
\hline \multicolumn{3}{|c|}{ Sieved with Supernate } & \multicolumn{3}{|c|}{ Insoluble Solids $(\mathrm{g})=$} & \multicolumn{2}{|c|}{0.5928} \\
\hline $\begin{array}{l}\text { Sieve Size } \\
\text { (microns or } \\
\text { mesh) }\end{array}$ & $\begin{array}{l}\text { Dry Wt of } \\
\text { Sieve }(\mathrm{g})\end{array}$ & $\begin{array}{l}\text { Wt. After } \\
\text { Sieving } \\
\text { Slurry and } \\
\text { Drying (g) }\end{array}$ & $\begin{array}{l}\text { Dry Wt of } \\
\text { Sieve (g) - } \\
\text { Wt. After } \\
\text { Sieving } \\
\text { Slurry and } \\
\text { Drying (g) }\end{array}$ & $\begin{array}{c}\text { Dissolved } \\
\text { Solids }(\mathrm{g})- \\
\text { From Table } \\
\text { B.1 }\end{array}$ & $\begin{array}{c}\text { Delta- } \\
\text { Dissolved } \\
\text { Solids (g) or } \\
\text { Corrected } \\
\text { Mass of } \\
\text { Solids on } \\
\text { Sieve (g) }\end{array}$ & $\begin{array}{c}\% \text { of } \\
\text { Insoluble } \\
\text { Solids } \\
\text { Collected } \\
\text { on Sieve }\end{array}$ & $\begin{array}{l}\text { \% of Solids } \\
\text { Below Sieve } \\
\quad \text { Size }\end{array}$ \\
\hline 38 & 80.0745 & 80.1906 & 0.1161 & 0.01165 & 0.1045 & 19.58 & 80.42 \\
\hline 32 & 81.1278 & 81.1375 & 0.0097 & 0.01215 & -0.0024 & 1.64 & 78.78 \\
\hline 25 & 72.9554 & 72.9576 & 0.0022 & 0.01485 & -0.0127 & 0.37 & 78.41 \\
\hline \multicolumn{7}{|c|}{ Total Sample Used $(\mathrm{g})=$} & \multirow{2}{*}{$\begin{array}{l}1.0427 \\
0.1225\end{array}$} \\
\hline \multicolumn{7}{|c|}{ Insoluble Solids $(\mathrm{g})=$} & \\
\hline 20 & 71.8797 & 71.8861 & 0.0064 & 0.01375 & -0.0074 & 0.00 & 78.41 \\
\hline $\begin{array}{c}16-18 \\
(165 \times 1400)\end{array}$ & 83.6655 & 83.6827 & 0.0172 & 0.0307 & -0.0135 & 0.00 & 78.41 \\
\hline $\begin{array}{c}12-14 \\
(200 \times 1400) \\
\end{array}$ & 84.7724 & 84.7766 & 0.0042 & 0.02485 & -0.0207 & 0.00 & 78.41 \\
\hline \multirow{2}{*}{\multicolumn{7}{|c|}{ Total Sample Used $(\mathrm{g})=$}} & \multirow{2}{*}{$\begin{array}{l}0.5198 \\
0.0611\end{array}$} \\
\hline & & & & & soluble Solids & & \\
\hline $\begin{array}{c}11-12 \\
(250 \times 1400) \\
\end{array}$ & 81.8233 & 81.8378 & 0.0145 & 0.055 & -0.0405 & 0.00 & 78.41 \\
\hline $\begin{array}{c}8-9 \\
(325 \times 2300) \\
\end{array}$ & 73.7102 & 73.7251 & 0.0149 & 0.0214 & -0.0065 & 0.00 & 78.41 \\
\hline $\begin{array}{c}5-6 \\
(510 \times 3600) \\
\end{array}$ & 80.8067 & 80.8165 & 0.0098 & 0.0237 & -0.0139 & 0.00 & 78.41 \\
\hline
\end{tabular}


WSRC-TR-2005-00077

Revision 0

Table B.2 Continued. Dissolved solids corrected data from Experiments 3.1-3.3 using values from Table A.2. The plot (Exp. 3.4) in Figure 3.7 is the average concentration from Experiments 3.2 and 3.3.

\begin{tabular}{|c|c|c|c|c|c|c|c|}
\hline \multirow{2}{*}{\multicolumn{3}{|c|}{ Exp.3 }} & \multicolumn{4}{|c|}{ Total Sample Used $(\mathrm{g})=$} & \multirow{2}{*}{$\begin{array}{l}5.1435 \\
0.6044\end{array}$} \\
\hline & & Sieved with Supernate & \multicolumn{4}{|c|}{ Insoluble Solids $(\mathrm{g})=$} & \\
\hline $\begin{array}{c}\text { Sieve Size } \\
\text { (microns or } \\
\text { mesh) }\end{array}$ & $\begin{array}{l}\text { Dry Wt of } \\
\text { Sieve }(\mathrm{g})\end{array}$ & $\begin{array}{l}\text { Wt. After } \\
\text { Sieving } \\
\text { Slurry and } \\
\text { Drying (g) }\end{array}$ & $\begin{array}{l}\text { Dry Wt of } \\
\text { Sieve (g) - } \\
\text { Wt. After } \\
\text { Sieving } \\
\text { Slurry and } \\
\text { Drying (g) }\end{array}$ & $\begin{array}{c}\text { Dissolved } \\
\text { Solids (g)- } \\
\text { From Table } \\
\text { B.1 }\end{array}$ & $\begin{array}{c}\text { Delta- } \\
\text { Dissolved } \\
\text { Solids (g) or } \\
\text { Corrected } \\
\text { Mass of } \\
\text { Solids on } \\
\text { Sieve (g) } \\
\end{array}$ & $\begin{array}{c}\% \text { of } \\
\text { Insoluble } \\
\text { Solids } \\
\text { Collected } \\
\text { on Sieve }\end{array}$ & $\begin{array}{l}\% \text { of Solids } \\
\text { Below } \\
\text { Sieve Size }\end{array}$ \\
\hline 38 & 80.4293 & 80.558 & 0.1287 & 0.01165 & 0.11705 & 19.37 & 80.63 \\
\hline 32 & 80.4921 & 80.5135 & 0.0214 & 0.01215 & 0.00925 & 1.53 & 79.10 \\
\hline 25 & 80.4471 & 80.4625 & 0.0154 & 0.01485 & 0.00055 & 0.09 & 79.01 \\
\hline \multicolumn{7}{|c|}{ Total Sample Used $(g)=$} & $\begin{array}{l}1.3053 \\
0.1534\end{array}$ \\
\hline 20 & 71.3248 & 71.362 & 0.005008 & 0.01375 & -0.00874 & 0.00 & 79.01 \\
\hline $\begin{array}{c}16-18 \\
(165 \times 1400)\end{array}$ & 75.0208 & 75.0355 & 0.0147 & 0.0307 & -0.016 & 0.00 & 79.01 \\
\hline $\begin{array}{c}12-14 \\
(200 \times 1400)\end{array}$ & 83.6747 & 83.6952 & 0.0205 & 0.02485 & -0.00435 & 0.00 & 79.01 \\
\hline \multicolumn{7}{|c|}{ Total Sample Used $(\mathrm{g})=$} & 0.5694 \\
\hline & & & & Insoluble & olids $(g)=$ & & 0.0669 \\
\hline $\begin{array}{c}11-12 \\
(250 \times 1400)\end{array}$ & 81.1583 & 81.1966 & 0.000538 & 0.055 & -0.05446 & 0.00 & 79.01 \\
\hline $\begin{array}{c}8-9 \\
(325 \times 2300)\end{array}$ & 73.608 & 73.6085 & 0.0005 & 0.0214 & -0.0209 & 0.00 & 79.01 \\
\hline $\begin{array}{c}5-6 \\
(510 \times 3600)\end{array}$ & 80.7602 & 80.7665 & 0.0063 & 0.0237 & -0.0174 & 0.00 & 79.01 \\
\hline
\end{tabular}


WSRC-TR-2005-00077

Revision 0

Table B.3 Experimental data from Experiment 5.3 - Sieving of supernate only to obtain dissolved solids correction factor.

\begin{tabular}{|c|c|c|c|}
\hline $\begin{array}{c}\text { Exp. } 1 \\
\text { (Sieve Size) }\end{array}$ & Dry Wt of Sieve (g) & $\begin{array}{l}\text { Wt. After Sieving } \\
\text { Supernate and Drying } \\
\text { (g) }\end{array}$ & $\begin{array}{c}\text { Dissolved Solids } \\
\text { Correction Factor (Dry } \\
\text { Wt of Sieve }(\mathrm{g}) \text { - Wt. } \\
\text { After Sieving Supernate } \\
\text { and Drying }(\mathrm{g})\end{array}$ \\
\hline 32 & 80.3484 & 80.36 & 0.0116 \\
\hline 25 & 80.3722 & 80.3849 & 0.0127 \\
\hline 20 & 71.7913 & 71.8001 & 0.0088 \\
\hline $16-18(165 \times 1400)$ & 74.8796 & 74.8968 & 0.0172 \\
\hline $12-14(200 \times 1400)$ & 75.2215 & 75.2388 & 0.0173 \\
\hline $11-12(250 \times 1400)$ & 75.4069 & 75.4403 & 0.0334 \\
\hline $8-9(325 \times 2300)$ & 74.9486 & 74.9649 & 0.0163 \\
\hline $6-7(450 \times 2750)$ & 74.7697 & 74.7858 & 0.0161 \\
\hline $5-6(510 \times 3600)$ & 80.4941 & 80.5134 & 0.0193 \\
\hline $\begin{array}{c}\text { Exp. } 2 \\
\text { (Sieve Size) }\end{array}$ & Dry Wt of Sieve (g) & $\begin{array}{l}\text { Wt. After Sieving } \\
\text { Supernate and Drying } \\
\text { (g) }\end{array}$ & $\begin{array}{c}\text { Dissolved Solids } \\
\text { Correction Factor (Dry } \\
\text { Wt of Sieve (g) - Wt. } \\
\text { After Sieving Supernate } \\
\text { and Drying (g) }\end{array}$ \\
\hline 32 & 80.3486 & 80.3559 & 0.0073 \\
\hline 25 & 72.6372 & 72.6448 & 0.0076 \\
\hline 20 & 71.7891 & 71.7946 & 0.0055 \\
\hline $16-18(165 \times 1400)$ & 83.4963 & 83.511 & 0.0147 \\
\hline $12-14(200 \times 1400)$ & 84.6375 & 84.6516 & 0.0141 \\
\hline $11-12(250 \times 1400)$ & 81.5862 & 81.5985 & 0.0123 \\
\hline $8-9(325 \times 2300)$ & 74.9476 & 74.9544 & 0.0068 \\
\hline $6-7(450 \times 2750)$ & 74.7681 & 74.7768 & 0.0087 \\
\hline $5-6(510 \times 3600)$ & 80.5047 & 80.5154 & 0.0107 \\
\hline (Sieve Size) & $\begin{array}{c}\text { Used Only Values } \\
\text { From Experiment } \\
2(\mathrm{~g})\end{array}$ & $\begin{array}{l}\text { Standard } \\
\text { Deviation }\end{array}$ & \%RSD \\
\hline 32 & 0.0073 & NA & NA \\
\hline 25 & 0.0076 & NA & NA \\
\hline 20 & 0.0055 & NA & NA \\
\hline $16-18(165 \times 1400)$ & 0.0147 & NA & NA \\
\hline $12-14(200 \times 1400)$ & 0.0141 & NA & NA \\
\hline $11-12(250 \times 1400)$ & 0.0123 & NA & NA \\
\hline $8-9(325 \times 2300)$ & 0.0068 & NA & NA \\
\hline $6-7(450 \times 2750)$ & 0.0087 & NA & NA \\
\hline $5-6(510 \times 3600)$ & 0.0107 & NA & NA \\
\hline
\end{tabular}


WSRC-TR-2005-00077

Revision 0

Table B.4 Dissolved solids corrected data from Experiments 5.1 and 5.2 using values from Table A.4. The plot in Figure 3.9 (Exp. 5.3) is the average concentration from Experiments 5.1 and 5.2.

Exp.1

Sieved with Supernate

\begin{tabular}{|c|c|c|c|c|c|c|c|}
\hline $\begin{array}{l}\text { Sieve Size (microns } \\
\text { or mesh) }\end{array}$ & $\begin{array}{l}\text { Dry Wt of } \\
\text { Sieve }(g)\end{array}$ & $\begin{array}{l}\text { Wt. After } \\
\text { Sieving } \\
\text { Slurry and } \\
\text { Drying (g) }\end{array}$ & $\begin{array}{l}\text { Dry Wt of } \\
\text { Sieve (g) - } \\
\text { Wt. After } \\
\text { Sieving } \\
\text { Slurry and } \\
\text { Drying (g) }\end{array}$ & $\begin{array}{l}\text { Dissolved } \\
\text { Solids (g)- } \\
\text { From Table } \\
\text { B.3 }\end{array}$ & $\begin{array}{l}\text { Delta- } \\
\text { Dissolved } \\
\text { Solids }(\mathrm{g}) \text { or } \\
\text { Corrected } \\
\text { Mass of Solids } \\
\text { on Sieve (g) }\end{array}$ & $\begin{array}{c}\% \text { of } \\
\text { Insoluble } \\
\text { Solids } \\
\text { Collected } \\
\text { on Sieve }\end{array}$ & $\begin{array}{c}\% \text { of } \\
\text { Solids } \\
\text { Below } \\
\text { Sieve Size }\end{array}$ \\
\hline 32 & 80.4422 & 80.489 & 0.0468 & 0.0073 & 0.0395 & 5.48 & 94.52 \\
\hline 25 & 72.7478 & 72.7555 & 0.0077 & 0.0076 & 0.0001 & 0.01 & 94.51 \\
\hline 20 & 73.2633 & 73.2754 & 0.0121 & 0.0055 & 0.0066 & 0.92 & 93.59 \\
\hline \multicolumn{7}{|c|}{ Total Sample Used $(\mathrm{g})=$} & $\begin{array}{l}1.0938 \\
0.1566\end{array}$ \\
\hline $16-18(165 \times 1400)$ & 84.271 & 84.2915 & 0.0205 & 0.0147 & -0.00423 & 0.00 & 93.59 \\
\hline $12-14(200 \times 1400)$ & 75.26 & 75.2705 & 0.0105 & 0.0141 & -0.0036 & 0.00 & 93.59 \\
\hline $11-12(250 \times 1400)$ & 81.1215 & 81.139 & 0.0175 & 0.0123 & 0.0052 & 3.32 & 95.75 \\
\hline \multicolumn{7}{|c|}{$\begin{array}{l}\text { Total Sample Used }(\mathrm{g})= \\
\text { Insoluble Solids }(\mathrm{g})=\end{array}$} & $\begin{array}{c}0.5879 \\
0.0842\end{array}$ \\
\hline $8-9(325 \times 2300)$ & 74.9575 & 74.9667 & 0.0092 & 0.0068 & -0.00118 & 0.00 & 95.75 \\
\hline $6-7(450 \times 2750)$ & 74.7879 & 74.7963 & 0.0084 & 0.0087 & -0.0003 & 0.00 & 95.75 \\
\hline $5-6(510 \times 3600)$ & 80.5448 & 80.5546 & 0.0098 & 0.0107 & -0.0009 & 0.00 & 95.75 \\
\hline \multicolumn{5}{|c|}{$\begin{array}{l}\text { Exp.2 } \\
\text { Sieved with Supernate }\end{array}$} & \multicolumn{2}{|c|}{ Insoluble Solids $(\mathrm{g})=$} & $\begin{array}{c}5.0799 \\
0.7274\end{array}$ \\
\hline $\begin{array}{l}\text { Sieve Size (microns } \\
\text { or mesh) }\end{array}$ & $\begin{array}{l}\text { Dry Wt of } \\
\text { Sieve }(g)\end{array}$ & $\begin{array}{l}\text { Wt. After } \\
\text { Sieving } \\
\text { Slurry and } \\
\text { Drying (g) }\end{array}$ & $\begin{array}{l}\text { Dry Wt of } \\
\text { Sieve (g) - } \\
\text { Wt. After } \\
\text { Sieving } \\
\text { Slurry and } \\
\text { Drying (g) }\end{array}$ & $\begin{array}{c}\text { Dissolved } \\
\text { Solids (g)- } \\
\text { From Table } \\
\text { B.3 }\end{array}$ & $\begin{array}{l}\text { Delta- } \\
\text { Dissolved } \\
\text { Solids }(\mathrm{g}) \text { or } \\
\text { Corrected } \\
\text { Mass of Solids } \\
\text { on Sieve }(\mathrm{g})\end{array}$ & $\begin{array}{c}\% \text { of } \\
\text { Insoluble } \\
\text { Solids } \\
\text { Collected } \\
\text { on Sieve }\end{array}$ & $\begin{array}{c}\% \text { of } \\
\text { Solids } \\
\text { Below } \\
\text { Sieve Size }\end{array}$ \\
\hline 32 & 81.0065 & 81.0568 & 0.0503 & 0.0073 & 0.043 & 5.91 & 94.09 \\
\hline 25 & 80.4064 & 80.4173 & 0.0109 & 0.0076 & 0.0033 & 0.45 & 93.64 \\
\hline 20 & 71.2716 & 71.2788 & 0.0072 & 0.0055 & 0.0017 & 0.23 & 93.40 \\
\hline \multicolumn{7}{|c|}{$\begin{array}{l}\text { Total Sample Used }(\mathrm{g})= \\
\text { Isoluble Solids }(\mathrm{g})=\end{array}$} & $\begin{array}{c}1.0932 \\
0.1639 \\
\end{array}$ \\
\hline $16-18(165 \times 1400)$ & 74.9406 & 74.963 & 0.0224 & 0.0147 & -0.0047 & 0.00 & 93.40 \\
\hline $12-14(200 \times 1400)$ & 83.622 & 83.6346 & 0.0126 & 0.0141 & -0.0015 & 0.00 & 93.40 \\
\hline $11-12(250 \times 1400)$ & 75.4684 & 75.488 & 0.0196 & 0.0123 & 0.0073 & 4.45 & 88.95 \\
\hline & \multicolumn{6}{|c|}{ Total Sample Used $(\mathrm{g})=$} & $\begin{array}{l}0.5705 \\
0.0817\end{array}$ \\
\hline $8-9(325 \times 2300)$ & 73.5325 & 73.5501 & 0.0176 & 0.0068 & -0.0709 & 0.00 & 88.95 \\
\hline $6-7(450 \times 2750)$ & 72.7239 & 72.733 & 0.0091 & 0.0087 & 0.0004 & 0.49 & 88.46 \\
\hline $5-6(510 \times 3600)$ & 80.5343 & 80.5405 & 0.0062 & 0.0107 & -0.0045 & 0.00 & 88.46 \\
\hline
\end{tabular}


WSRC-TR-2005-00077

Revision 0

Table B.5 Experimental data from Experiment 7.3 - Sieving of supernate only to obtain dissolved solids correction factor.

\begin{tabular}{|c|c|c|c|}
\hline $\begin{array}{c}\text { Exp. } 1 \\
\text { (Sieve Size) }\end{array}$ & Dry Wt of Sieve (g) & $\begin{array}{l}\text { Wt. After Sieving } \\
\text { Supernate and Drying } \\
(\mathrm{g})\end{array}$ & $\begin{array}{c}\text { Dissolved Solids } \\
\text { Correction Factor (Dry } \\
\text { Wt of Sieve }(\mathrm{g}) \text { - Wt. } \\
\text { After Sieving Supernate } \\
\text { and Drying (g) }\end{array}$ \\
\hline 150 & 74.2656 & 74.2727 & 0.0071 \\
\hline 75 & 73.9841 & 73.991 & 0.0069 \\
\hline 45 & 75.0312 & 75.0375 & 0.0063 \\
\hline 32 & 80.9755 & 80.9827 & 0.0072 \\
\hline 25 & 72.6394 & 72.6435 & 0.0041 \\
\hline $16-18(165 \times 1400)$ & 84.24 & 84.2471 & 0.0071 \\
\hline $12-14(200 \times 1400)$ & 83.6006 & 83.6067 & 0.0061 \\
\hline $11-12(250 \times 1400)$ & 81.5867 & 81.5924 & 0.0057 \\
\hline $8-9(325 \times 2300)$ & 73.4513 & 73.4569 & 0.0056 \\
\hline $6-7(450 \times 2750)$ & 72.6008 & 72.6076 & 0.0068 \\
\hline $5-6(510 \times 3600)$ & 80.5042 & 80.517 & 0.0128 \\
\hline $\begin{array}{c}\text { Exp. } 2 \\
\text { (Sieve Size) }\end{array}$ & Dry Wt of Sieve (g) & $\begin{array}{l}\text { Wt. After Sieving } \\
\text { Supernate and Drying } \\
(\mathrm{g})\end{array}$ & $\begin{array}{c}\text { Dissolved Solids } \\
\text { Correction Factor (Dry } \\
\text { Wt of Sieve }(\mathrm{g}) \text { - Wt. } \\
\text { After Sieving Supernate } \\
\text { and Drying }(\mathrm{g}) \\
\end{array}$ \\
\hline 150 & 81.3019 & 81.3099 & 0.008 \\
\hline 75 & 73.9657 & 73.975 & 0.0093 \\
\hline 45 & 73.9397 & 73.9476 & 0.0079 \\
\hline 32 & 73.6682 & 73.6774 & 0.0092 \\
\hline 25 & 72.7268 & 72.7338 & 0.007 \\
\hline $16-18(165 \times 1400)$ & 83.4961 & 83.5085 & 0.0124 \\
\hline $12-14(200 \times 1400)$ & 84.639 & 84.6484 & 0.0094 \\
\hline $11-12(250 \times 1400)$ & 81.102 & 81.1118 & 0.0098 \\
\hline $8-9(325 \times 2300)$ & 75.261 & 75.2679 & 0.0069 \\
\hline $6-7(450 \times 2750)$ & 74.3548 & 74.3601 & 0.0053 \\
\hline $5-6(510 \times 3600)$ & 74.8136 & 74.8241 & 0.0105 \\
\hline (Sieve Size) & $\begin{array}{c}\text { Average Dissolved } \\
\text { Solids on Each Sieve } \\
\text { From Two Experiments } \\
(\mathrm{g})\end{array}$ & Standard Deviation & $\%$ RSD \\
\hline 150 & 0.00755 & 0.00755 & 8.4291 \\
\hline 75 & 0.0081 & 0.0081 & 20.9513 \\
\hline 45 & 0.0071 & 0.0071 & 15.9348 \\
\hline 32 & 0.0082 & 0.0082 & 17.2465 \\
\hline 25 & 0.00555 & 0.00555 & 36.9479 \\
\hline $16-18(165 \times 1400)$ & 0.00975 & 0.00975 & 38.4376 \\
\hline $12-14(200 \times 1400)$ & 0.00775 & 0.00775 & 30.1091 \\
\hline $11-12(250 \times 1400)$ & 0.00775 & 0.00775 & 37.4082 \\
\hline $8-9(325 \times 2300)$ & 0.00625 & 0.00625 & 14.7078 \\
\hline $6-7(450 \times 2750)$ & 0.00605 & 0.00605 & 17.5316 \\
\hline $5-6(510 \times 3600)$ & 0.01165 & 0.01165 & 13.9600 \\
\hline
\end{tabular}


Table B.6 Dissolved solids corrected data for Experiments 7.1 and 7.2 using values from Table A.5. The plot in Figure 3.11 (Exp. 7.3) is the average concentration from Experiments 7.1 and 7.2.

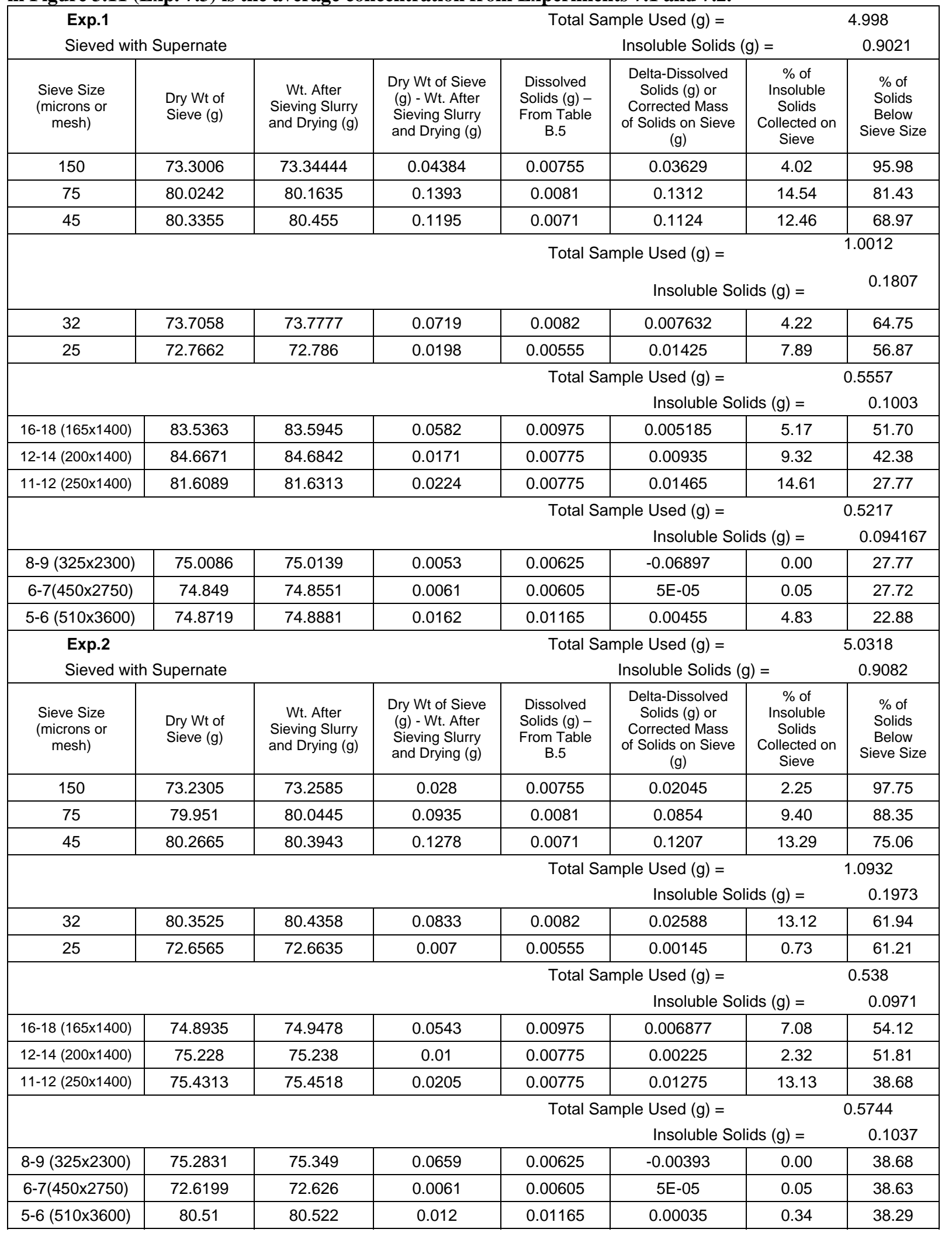


WSRC-TR-2005-00077

Revision 0

\section{APPENDIX C}

Sample Calculations 
Table C.1 Sample calculations based on Experiment 6.1. The experimentally obtained data is in Table A.5 and the calculation formulas are in Table C.2. Calculations of this type were done on data collected from Experiments 3.3, 4.1-4.2, 5.1-5.2, 6.1-6.2 and 7.1-7.2.

\begin{tabular}{|c|c|c|c|c|c|c|c|}
\hline & $\mathrm{B}$ & C & $\mathrm{D}$ & $E$ & $\mathrm{~F}$ & G & $\mathrm{H}$ \\
\hline 15 & Exp. 6.1 & & & & \multicolumn{2}{|c|}{ Total Sample Used $(\mathrm{g})=$} & 10.3127 \\
\hline 16 & \multicolumn{2}{|c|}{ Sieved with Water } & & & & Insoluble Solids $(\mathrm{g})=$ & 1.8614 \\
\hline 17 & $\begin{array}{c}\text { Sieve Size } \\
\text { (microns or } \\
\text { mesh) }\end{array}$ & $\begin{array}{l}\text { Dry Wt } \\
\text { of Sieve } \\
(\mathrm{g})\end{array}$ & $\begin{array}{l}\text { Wt. } \\
\text { After } \\
\text { Sieving } \\
\text { Slurry } \\
\text { and } \\
\text { Drying } \\
\text { (g) }\end{array}$ & $\begin{array}{l}\text { Dry Wt } \\
\text { of Sieve } \\
\text { (g) - Wt. } \\
\text { After } \\
\text { Sieving } \\
\text { Slurry } \\
\text { and } \\
\text { Drying } \\
\text { (g) }\end{array}$ & $\begin{array}{c}\% \text { of } \\
\text { Insolub } \\
\text { le } \\
\text { Solids } \\
\text { Collect } \\
\text { ed on } \\
\text { Sieve }\end{array}$ & $\begin{array}{c}\% \text { of Solids Below } \\
\text { Sieve Size }\end{array}$ & \\
\hline 18 & 150 & 73.3513 & 73.3994 & 0.0481 & 2.58 & 97.42 & \\
\hline 19 & 75 & 80.0686 & 80.2415 & 0.1729 & 9.29 & 88.13 & \\
\hline 20 & 45 & 80.3802 & 80.581 & 0.2008 & 10.79 & 77.34 & \\
\hline 21 & & & & & \multicolumn{2}{|c|}{ Total Sample Used $(\mathrm{g})=$} & 5.4166 \\
\hline 22 & & & & & & Insoluble Solids $(\mathrm{g})=$ & 0.9777 \\
\hline 23 & 32 & 81.0435 & 81.3794 & 0.1144 & 11.70 & 65.64 & \\
\hline 24 & 25 & 72.8489 & 72.8947 & 0.0458 & 4.68 & 60.96 & \\
\hline 25 & & & & & \multicolumn{2}{|c|}{ Total Sample Used $(\mathrm{g})=$} & 0.5977 \\
\hline 26 & & & & & & Insoluble Solids $(\mathrm{g})=$ & 0.1079 \\
\hline 27 & $\begin{array}{c}16-18 \\
(165 \times 1400)\end{array}$ & 84.298 & 84.347 & 0.0069 & 6.38 & 54.58 & \\
\hline 28 & $\begin{array}{c}12-14 \\
(200 \times 1400)\end{array}$ & 84.7025 & 84.7089 & 0.0064 & 5.93 & 48.65 & \\
\hline 29 & $\begin{array}{c}11-12 \\
(250 \times 1400)\end{array}$ & 75.5133 & 75.5203 & 0.007 & 6.49 & 42.16 & \\
\hline 30 & & & & & \multicolumn{2}{|c|}{ Total Sample Used $(\mathrm{g})=$} & 0.5404 \\
\hline 31 & & & & & & Insoluble Solids $(\mathrm{g})=$ & 0.0975 \\
\hline 32 & $8-9(325 \times 2300)$ & 75.5048 & 75.5675 & 0.0035 & 3.63 & 38.53 & \\
\hline 33 & $6-7(450 \times 2750)$ & 74.7202 & 74.7218 & 0.0016 & 1.64 & 36.89 & \\
\hline 34 & $5-6(510 \times 3600)$ & 80.585 & 80.5865 & 0.0015 & 1.54 & 35.36 & \\
\hline
\end{tabular}


WSRC-TR-2005-00077

Revision 0

Table C.2 Sample calculations based on Experiment 6.1. Calculations of this type were done on data collected from Experiments 3.3, 4.1-4.2, 5.1-5.2, 6.1-6.2 and 7.1-7.2.

\begin{tabular}{|c|c|c|c|c|c|c|c|}
\hline & $\mathrm{B}$ & $\mathrm{C}$ & $\mathrm{D}$ & $E$ & $\mathrm{~F}$ & G & $\mathrm{H}$ \\
\hline 15 & Exp. 6.1 & & & & & Total Sample Used $(\mathrm{g})=$ & 10.3127 \\
\hline 16 & Sieved with Wate & & & & & Insoluble Solids $(\mathrm{g})=$ & 1.8614 \\
\hline 17 & $\begin{array}{l}\text { Sieve Size } \\
\text { (microns or } \\
\text { mesh) }\end{array}$ & $\begin{array}{l}\text { Dry Wt } \\
\text { of Sieve } \\
\text { (g) }\end{array}$ & $\begin{array}{l}\text { Wt. } \\
\text { After } \\
\text { Sieving } \\
\text { Slurry } \\
\text { and } \\
\text { Drying } \\
\text { (g) }\end{array}$ & $\begin{array}{l}\text { Dry Wt of Sieve } \\
\text { (g) - Wt. After } \\
\text { Sieving Slurry } \\
\text { and Drying (g) }\end{array}$ & $\begin{array}{l}\% \text { of Insoluble } \\
\text { Solids Collected } \\
\text { on Sieve }\end{array}$ & $\begin{array}{l}\% \text { of Solids Below Sieve } \\
\text { Size }\end{array}$ & \\
\hline 18 & 150 & 73.3513 & 73.3994 & $=\mathrm{D} 18-\mathrm{C} 18$ & $=\mathrm{E} 18 / \$ \mathrm{H} \$ 16 * 100$ & $=100-\mathrm{F} 18$ & \\
\hline 19 & 75 & 80.0686 & 80.2415 & $=\mathrm{D} 19-\mathrm{C} 19$ & $=\mathrm{E} 19 / \$ \mathrm{H} \$ 16 * 100$ & $=100-F 18-F 19$ & \\
\hline 20 & 45 & 80.3802 & 80.581 & $=\mathrm{D} 20-\mathrm{C} 20$ & $=\mathrm{E} 20 / \$ \mathrm{H} \$ 16 * 100$ & $=100-F 18-F 19-F 20$ & \\
\hline 21 & & & & & & Total Sample Used $(\mathrm{g})=$ & 5.4166 \\
\hline 22 & & & & & & Insoluble Solids $(\mathrm{g})=$ & 0.9777 \\
\hline 23 & 32 & 81.0435 & 81.3794 & $\begin{array}{l}=(\mathrm{D} 23-\mathrm{C} 23)-(\mathrm{H} 22) \\
*(100-\mathrm{G} 20) / 100\end{array}$ & $=\mathrm{E} 23 / \$ \mathrm{H} \$ 22 * 100$ & $=100-F 18-F 19-F 20-F 23$ & \\
\hline 24 & 25 & 72.8489 & 72.8947 & $=\mathrm{D} 24-\mathrm{C} 24$ & $=\mathrm{E} 24 / \$ \mathrm{H} \$ 22 * 100$ & $=100-F 18-F 19-F 20-F 23-F 24$ & \\
\hline 25 & & & & & & Total Sample Used $(\mathrm{g})=$ & 0.5977 \\
\hline 26 & & & & & & Insoluble Solids $(\mathrm{g})=$ & 0.1079 \\
\hline 27 & $16-18(165 \times 1400)$ & 84.298 & 84.347 & $\begin{array}{l}=(\mathrm{D} 27-\mathrm{C} 27)-(\mathrm{H} 26) \\
\star(100-\mathrm{G} 24) / 100\end{array}$ & $=\mathrm{E} 27 / \$ \mathrm{H} \$ 26 * 100$ & $\begin{array}{l}=100-F 18-F 19-F 20-F 23-F 24 \\
-F 27\end{array}$ & \\
\hline 28 & $12-14(200 \times 1400)$ & 84.7025 & 84.7089 & $=\mathrm{D} 28-\mathrm{C} 28$ & $=\mathrm{E} 28 / \$ \mathrm{H} \$ 26 * 100$ & $\begin{array}{l}=100-F 18-F 19-F 20-F 23-F 24 \\
-F 27-F 28\end{array}$ & \\
\hline 29 & $11-12(250 \times 1400)$ & 75.5133 & 75.5203 & $=\mathrm{D} 29-\mathrm{C} 29$ & $=\mathrm{E} 29 / \$ \mathrm{H} \$ 26 * 100$ & $\begin{array}{l}=100-F 18-F 19-F 20-F 23-F 24 \\
\text {-F27-F28-F29 }\end{array}$ & \\
\hline 30 & & & & & & Total Sample Used $(\mathrm{g})=$ & 0.5404 \\
\hline 31 & & & & & & Insoluble Solids $(\mathrm{g})=$ & 0.0975 \\
\hline 32 & $8-9(325 \times 2300)$ & 75.5048 & 75.5675 & $\begin{array}{l}=(\mathrm{D} 32-\mathrm{C} 32) \star(\mathrm{H} 31) \\
\star(100-\mathrm{G} 29) / 100\end{array}$ & $=\mathrm{E} 32 / \$ \mathrm{H} \$ 31 * 100$ & $\begin{array}{l}=100-F 18-F 19-F 20-F 23-F 24 \\
-F 27-F 28-F 29-F 32\end{array}$ & \\
\hline 33 & $6-7(450 \times 2750)$ & 74.7202 & 74.7218 & $=\mathrm{D} 33-\mathrm{C} 33$ & $=\mathrm{E} 33 / \$ \mathrm{H} \$ 31 * 100$ & $\begin{array}{l}=100-F 18-F 19-F 20-F 23-F 24 \\
\text {-F27-F28-F29-F32-F33 }\end{array}$ & \\
\hline 34 & $5-6(510 \times 3600)$ & 80.585 & 80.5865 & $=\mathrm{D} 34-\mathrm{C} 34$ & $=\mathrm{E} 34 / \$ \mathrm{H} \$ 31 * 100$ & $\begin{array}{l}=100-F 18-F 19-F 20-F 23-F 24 \\
\text {-F27-F28-F29-F32-F33-F34 }\end{array}$ & \\
\hline
\end{tabular}


WSRC-TR-2005-00077

Revision 0

Table C.3 Sample calculations based on Experiment 7.3 - Determination of Dissolved Solids Correction Factor. The experimental numbers are in Table B.5 and B.6 and the calculation formulas are in Table C.4. Calculations of this type were done on data collected from Experiments 3.4, 4.3, 5.3, 6.3 and 7.3.

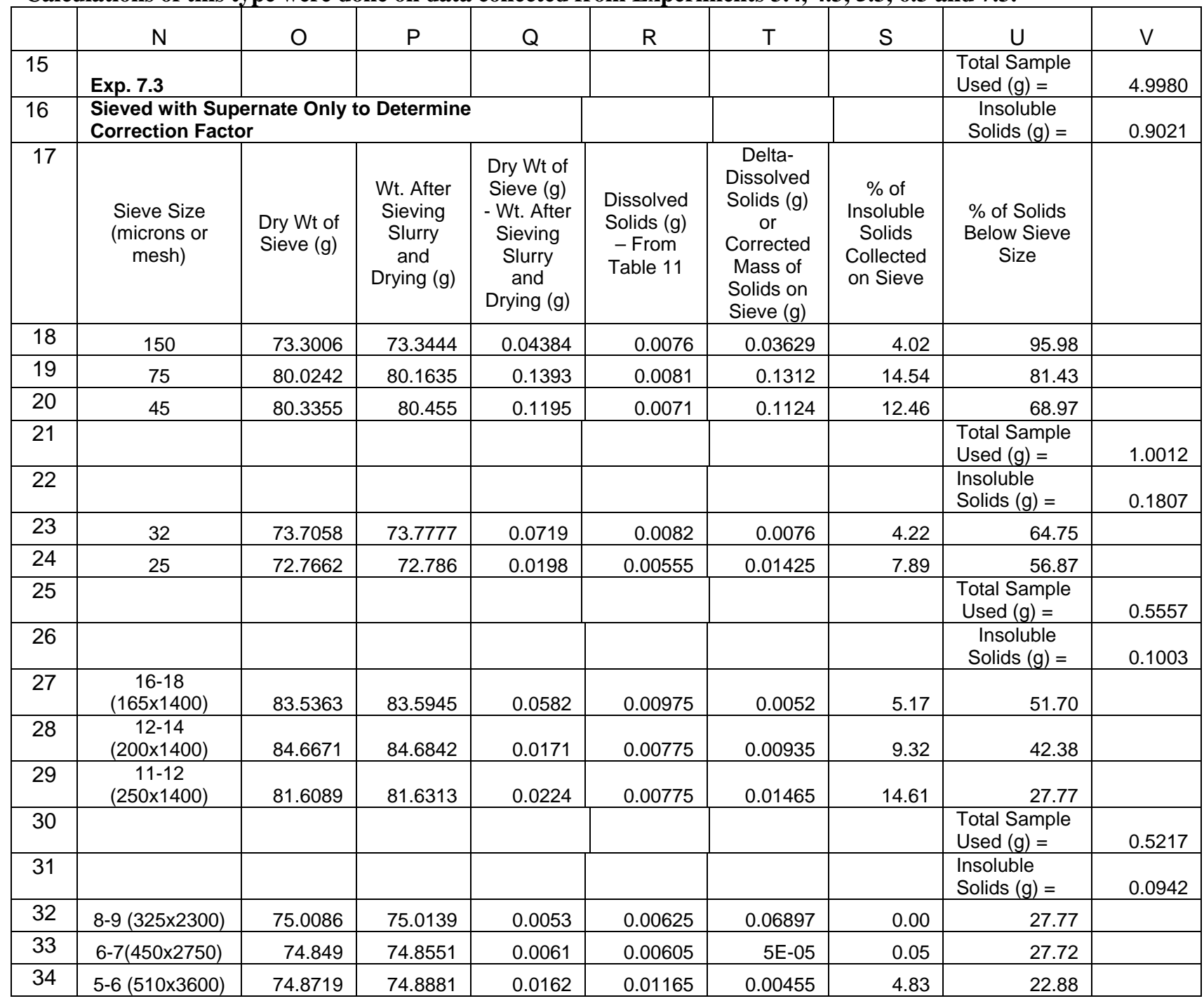


WSRC-TR-2005-00077

Revision 0

Table C.4 Sample calculations based on Experiment 7.3 - Determination of Dissolved Solids Correction

Factor. The experimental numbers are in Table B.5 and B.6 and the calculation formulas are in Table C.5. Calculations of this type were done on data collected from Experiments 3.4, 4.3, 5.3, 6.3 and 7.3.

\begin{tabular}{|c|c|c|c|c|c|c|c|c|c|}
\hline & $\mathrm{N}$ & $\mathrm{O}$ & $\mathrm{P}$ & $\mathrm{Q}$ & $\mathrm{R}$ & $\mathrm{T}$ & $\mathrm{S}$ & $U$ & $\mathrm{~V}$ \\
\hline 15 & Exp. 7.3 & & & & & & & Total Sample Used $(\mathrm{q})=$ & 4.998 \\
\hline 16 & \multicolumn{3}{|c|}{$\begin{array}{l}\text { Sieved with Supernate Only to } \\
\text { Determine Correction Factor }\end{array}$} & & & & & Insoluble Solids $(\mathrm{g})=$ & 0.9021 \\
\hline 17 & $\begin{array}{l}\text { Sieve } \\
\text { Size } \\
\text { (microns } \\
\text { or mesh) }\end{array}$ & $\begin{array}{l}\text { Dry Wt } \\
\text { of Sieve } \\
\text { (g) }\end{array}$ & $\begin{array}{l}\text { Wt. } \\
\text { After } \\
\text { Sieving } \\
\text { Slurry } \\
\text { and } \\
\text { Drying } \\
\text { (g) }\end{array}$ & $\begin{array}{l}\text { Dry Wt of } \\
\text { Sieve (g) - } \\
\text { Wt. After } \\
\text { Sieving } \\
\text { Slurry and } \\
\text { Drying (g) }\end{array}$ & $\begin{array}{c}\text { Dissolved } \\
\text { Solids }(\mathrm{g}) \\
\text { - From } \\
\text { Table } 11\end{array}$ & $\begin{array}{l}\text { Delta-Dissolved } \\
\text { Solids }(\mathrm{g}) \text { or } \\
\text { Corrected Mass of } \\
\text { Solids on Sieve }(\mathrm{g})\end{array}$ & $\begin{array}{l}\% \text { of Insoluble } \\
\text { Solids Collected } \\
\text { on Sieve }\end{array}$ & $\begin{array}{c}\% \text { of Solids Below Sieve } \\
\text { Size }\end{array}$ & \\
\hline 18 & 150 & 73.3006 & 73.3444 & $=\mathrm{P} 18-\mathrm{O} 18$ & 0.00755 & $=Q 18-R 18$ & $=\mathrm{S} 18 / \$ \vee \$ 16 * 100$ & $=100-\mathrm{T} 18$ & \\
\hline 19 & 75 & 80.0242 & 80.1635 & $=\mathrm{P} 19-\mathrm{O} 19$ & 0.0081 & $=\mathrm{Q} 19-\mathrm{R} 19$ & $=\mathrm{S} 19 / \$ \mathrm{H} \$ 16 * 100$ & $=100-\mathrm{T} 18-\mathrm{T} 19$ & \\
\hline 20 & 45 & 80.3355 & 80.455 & $=P 20-020$ & 0.0071 & $=\mathrm{Q} 20-\mathrm{R} 20$ & $=\mathrm{S} 20 / \$ \mathrm{H} \$ 16 * 100$ & $=100-\mathrm{T} 18-\mathrm{T} 19-\mathrm{T} 20$ & \\
\hline 21 & & & & & & & & Total Sample Used $(\mathrm{g})=$ & 1.0012 \\
\hline 22 & & & & & & & & Insoluble Solids $(\mathrm{g})=$ & 0.1807 \\
\hline 23 & 32 & 73.7058 & 73.7777 & $=\mathrm{P} 23-\mathrm{O} 23$ & 0.0082 & $\begin{array}{l}=(\mathrm{Q} 23-\mathrm{R} 23)-(\mathrm{V} 22) \\
*(100-\mathrm{U} 20) / 100\end{array}$ & $=\mathrm{S} 23 / \$ \vee \$ 22 * 100$ & $=100-\mathrm{T} 18-\mathrm{T} 19-\mathrm{T} 20-\mathrm{T} 23$ & \\
\hline 24 & 25 & 72.7662 & 72.786 & $=\mathrm{P} 24-\mathrm{O} 24$ & 0.0056 & $=\mathrm{Q} 24-\mathrm{R} 24$ & $=\mathrm{S} 24 / \$ \vee \$ 22 * 100$ & $=100-\mathrm{T} 18-\mathrm{T} 19-\mathrm{T} 20-\mathrm{T} 23-\mathrm{T} 24$ & \\
\hline 25 & & & & & & & & Total Sample Used $(\mathrm{g})=$ & 0.5557 \\
\hline 26 & & & & & & & & Insoluble Solids $(\mathrm{g})=$ & 0.1003 \\
\hline 27 & $\begin{array}{c}16-18 \\
(165 \times 1400)\end{array}$ & 83.5363 & 83.5945 & $=\mathrm{P} 27-\mathrm{O} 27$ & 0.0098 & $\begin{array}{l}=(\mathrm{Q} 27-\mathrm{R} 27)-(\mathrm{V} 26) \\
*(100-\mathrm{U} 24) / 100\end{array}$ & $=\mathrm{S} 27 / \$ \vee \$ 26 * 100$ & $\begin{array}{l}=100-\mathrm{T} 18-\mathrm{T} 19-\mathrm{T} 20-\mathrm{T} 23-\mathrm{T} 24 \\
-\mathrm{T} 27\end{array}$ & \\
\hline 28 & $\begin{array}{c}12-14 \\
(200 \times 1400) \\
\end{array}$ & 84.6671 & 84.6842 & $=\mathrm{P} 28-\mathrm{O} 28$ & 0.0078 & $=\mathrm{Q} 28-\mathrm{R} 28$ & $=\mathrm{S} 28 / \$ \vee \$ 26 * 100$ & $\begin{array}{l}=100-\mathrm{T} 18-\mathrm{T} 19-\mathrm{T} 20-\mathrm{T} 23-\mathrm{T} 24 \\
-\mathrm{T} 27-\mathrm{T} 28\end{array}$ & \\
\hline 29 & $\begin{array}{c}11-12 \\
(250 \times 1400)\end{array}$ & 81.6089 & 81.6313 & $=\mathrm{P} 29-\mathrm{O} 29$ & 0.0078 & $=Q 29-R 29$ & $=\mathrm{S} 29 / \$ \vee \$ 26 * 100$ & $\begin{array}{l}=100-\mathrm{T} 18-\mathrm{T} 19-\mathrm{T} 20-\mathrm{T} 23-\mathrm{T} 24 \\
\text {-T27-T28-T29 }\end{array}$ & \\
\hline 30 & & & & & & & & Total Sample Used $(\mathrm{g})=$ & 0.5217 \\
\hline 31 & & & & & & & & Insoluble Solids $(\mathrm{g})=$ & 0.0942 \\
\hline 32 & $\begin{array}{c}8-9 \\
(325 \times 2300)\end{array}$ & 75.0086 & 75.0139 & $=\mathrm{P} 32-\mathrm{O} 32$ & 0.0063 & $\begin{array}{l}=(\mathrm{Q} 32-\mathrm{R} 32)-(\mathrm{V} 31) \\
*(100-\mathrm{U} 29) / 100\end{array}$ & 0 & $\begin{array}{l}=100-\mathrm{T} 18-\mathrm{T} 19-\mathrm{T} 20-\mathrm{T} 23-\mathrm{T} 24 \\
\text {-T27-T28-T29-T32 }\end{array}$ & \\
\hline 33 & $\begin{array}{c}6-7 \\
(450 \times 2750) \\
\end{array}$ & 74.849 & 74.8551 & $=\mathrm{P} 33-\mathrm{O} 33$ & 0.0061 & $=Q 33-R 33$ & $=\mathrm{S} 33 / \$ \mathrm{~V} \$ 31 * 100$ & $\begin{array}{l}=100-\mathrm{T} 18-\mathrm{T} 19-\mathrm{T} 20-\mathrm{T} 23-\mathrm{T} 24 \\
-\mathrm{T} 27-\mathrm{T} 28-\mathrm{T} 29-\mathrm{T} 32-\mathrm{T} 33\end{array}$ & \\
\hline 34 & $\begin{array}{c}5-6 \\
(510 \times 3600)\end{array}$ & 74.8719 & 74.8881 & $=\mathrm{P} 34-\mathrm{O} 34$ & 0.0116 & $=\mathrm{Q} 34-\mathrm{R} 34$ & $=\mathrm{S} 34 / \$ \mathrm{~V} \$ 31 * 100$ & $\begin{array}{l}=100-\mathrm{T} 18-\mathrm{T} 19-\mathrm{T} 20-\mathrm{T} 23-\mathrm{T} 24 \\
-\mathrm{T} 27-\mathrm{T} 28-\mathrm{T} 29-\mathrm{T} 32-\mathrm{T} 33-\mathrm{T} 34\end{array}$ & \\
\hline
\end{tabular}


WSRC-TR-2005-00077

Revision 0

This page intentionally left blank. 
WSRC-TR-2005-00077

Revision 0

\section{APPENDIX D}

Microtrac Data 
Figure D.1 Microtrac analysis of NIST 1984 standard on a volume basis.

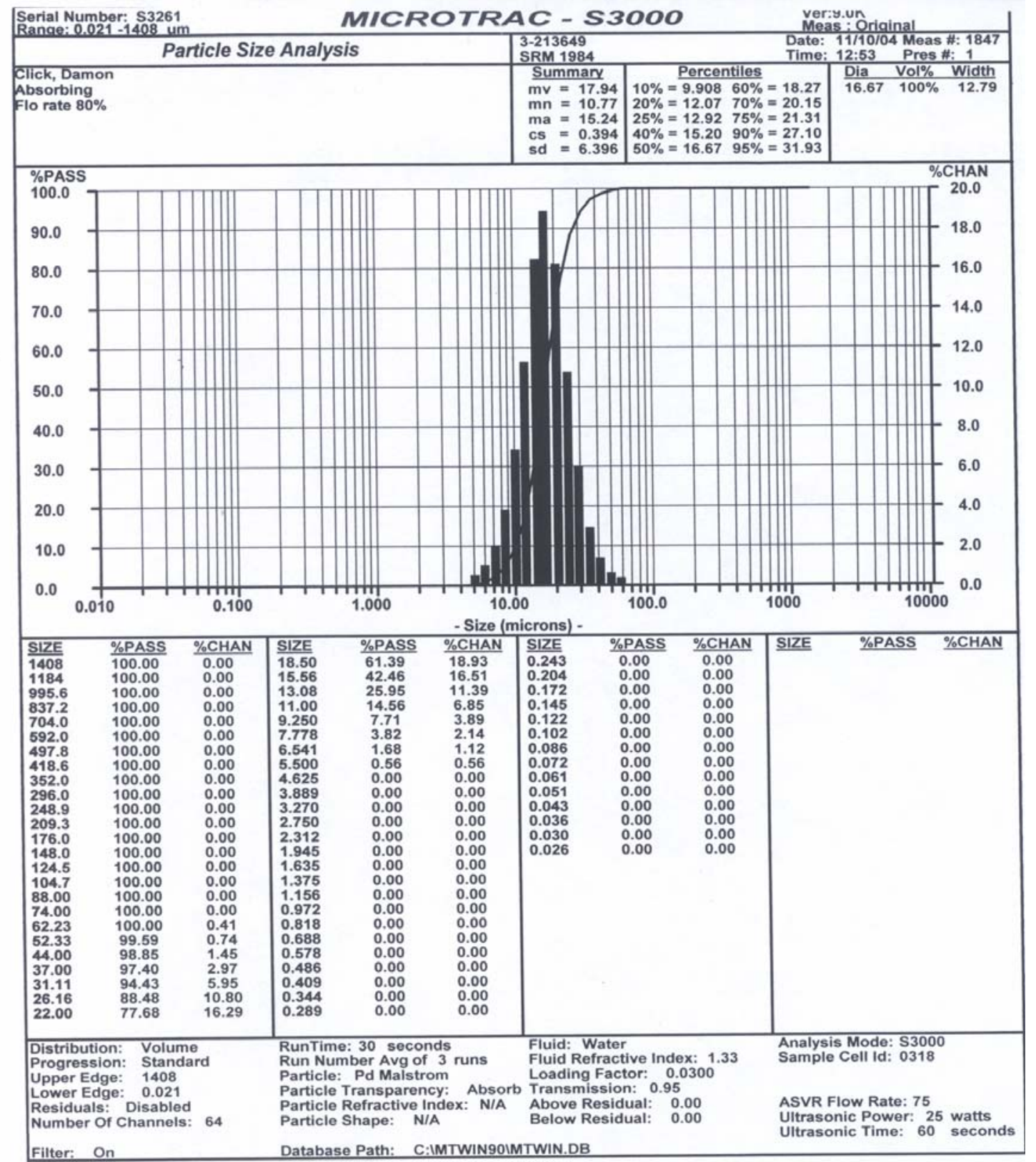


Figure D.2 Microtrac analysis of solids collected on the 20 micron sieve from Exp 3 which was done with DI $\mathrm{H}_{2} \mathrm{O}$. Data is on a volume basis.

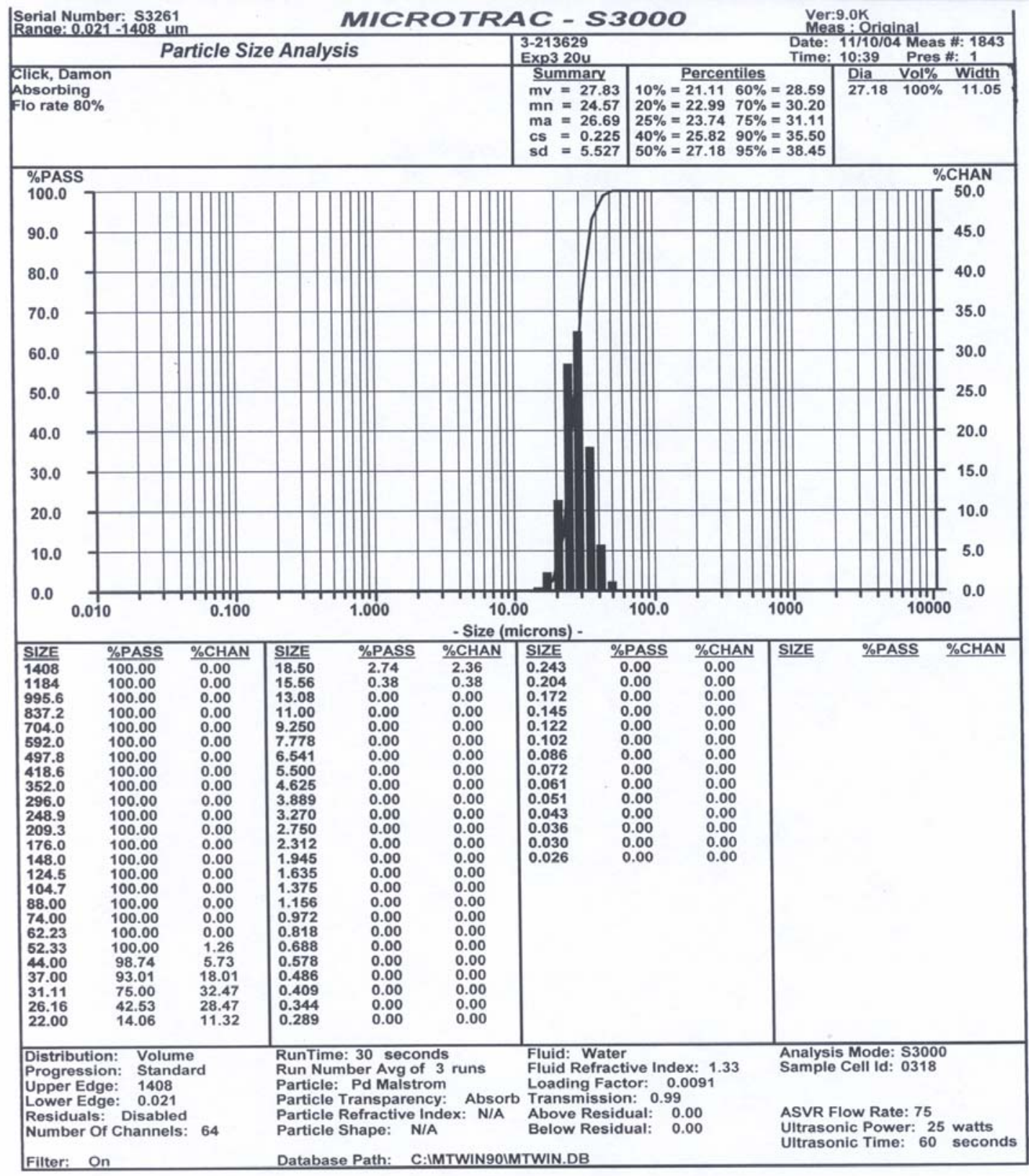


Figure D.3 Microtrac analysis of solids collected on the 5-6 micron sieve (510x3600 mesh). Data is on a volume basis.

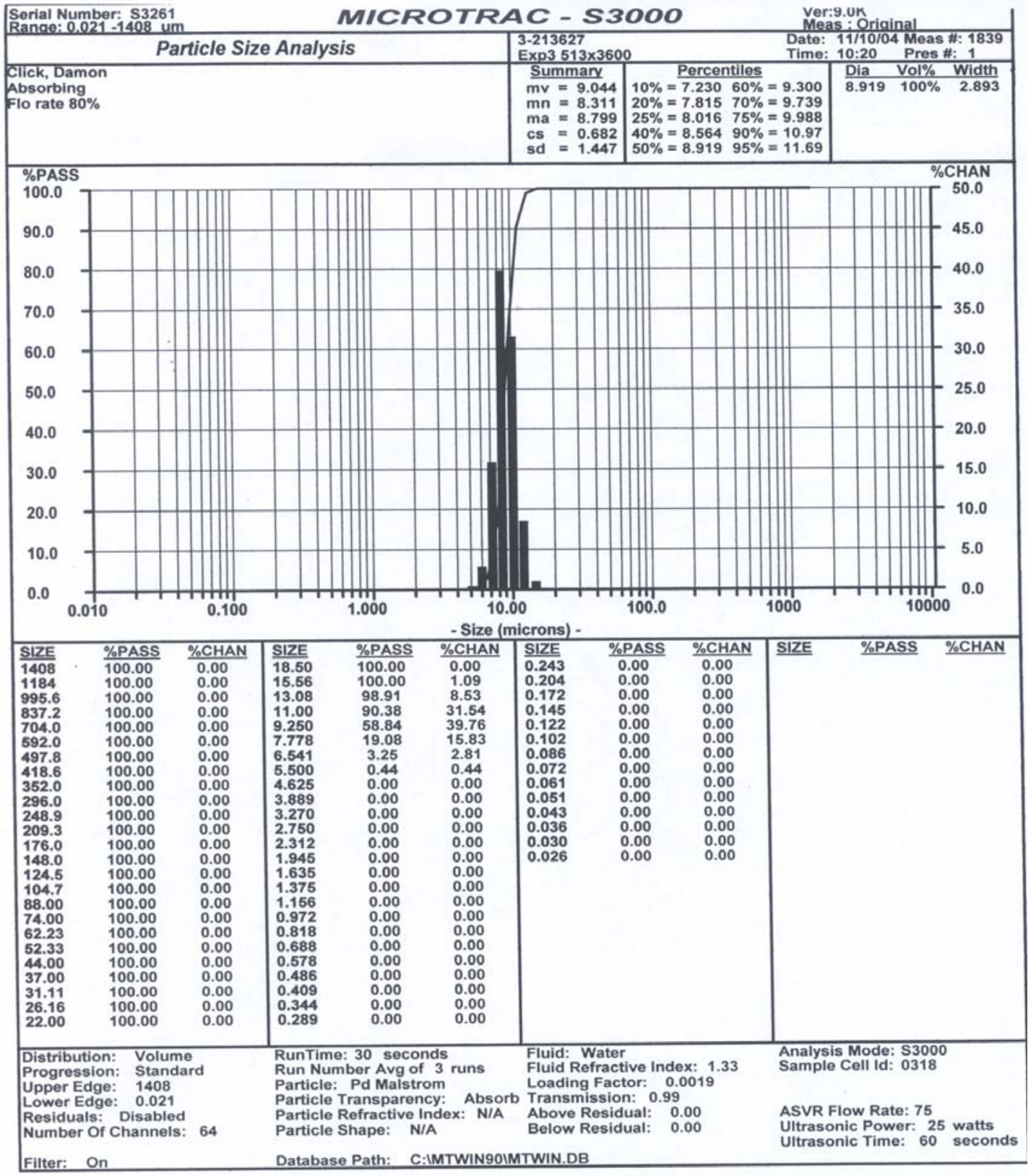


Figure D.4 Microtrac analysis of solids collected on the 8-9 micron sieve (325x2300 mesh) from Exp 3 which was done with DI $\mathrm{H}_{2} \mathrm{O}$. Data is on a volume basis.

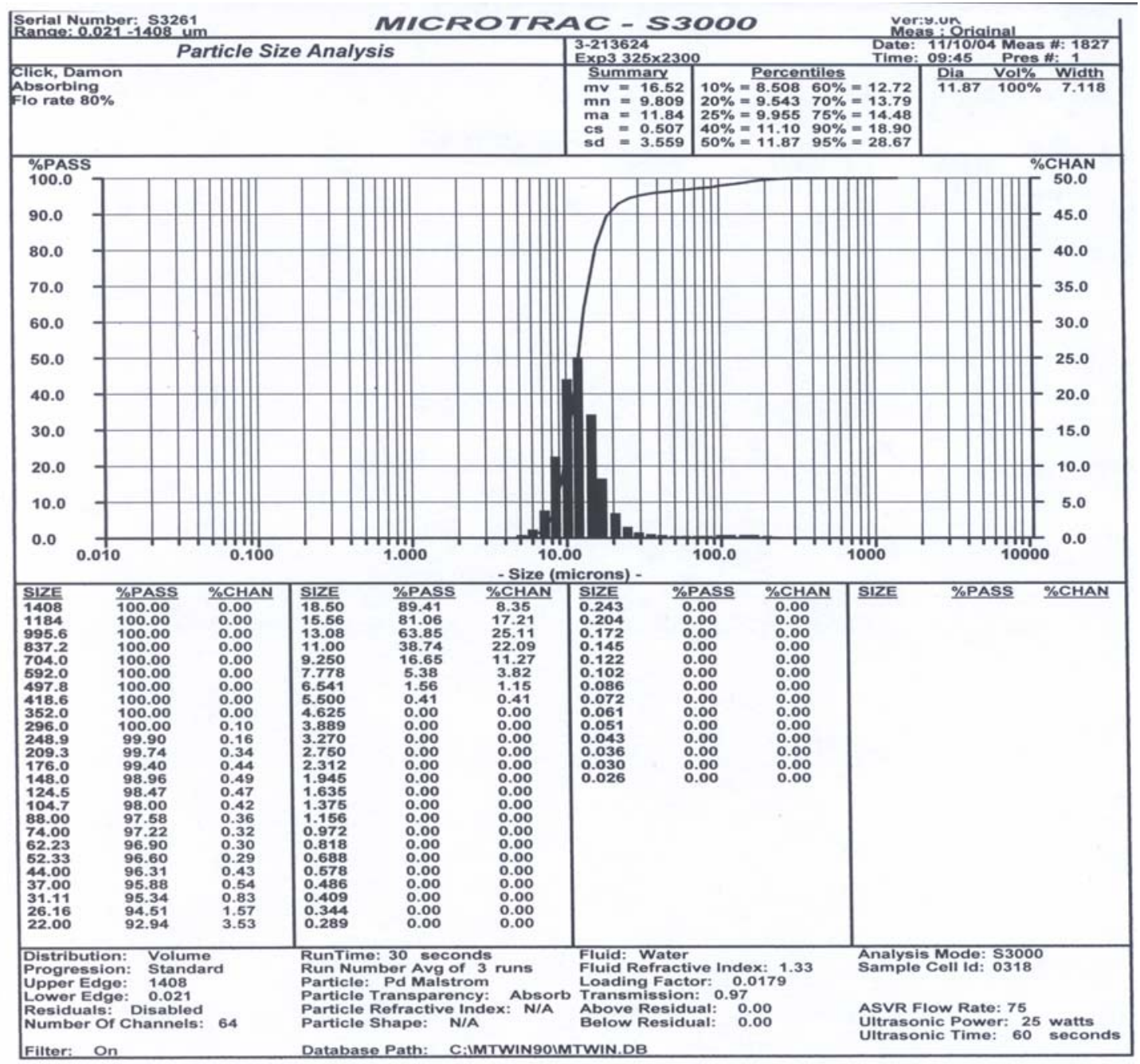


WSRC-TR-2005-00077

Revision 0

Figure D.5 Microtrac analysis of solids collected on the 11-12 micron sieve (250x1400) from Exp 3 which was done with DI $\mathrm{H}_{2} \mathrm{O}$. Data is on a volume basis.

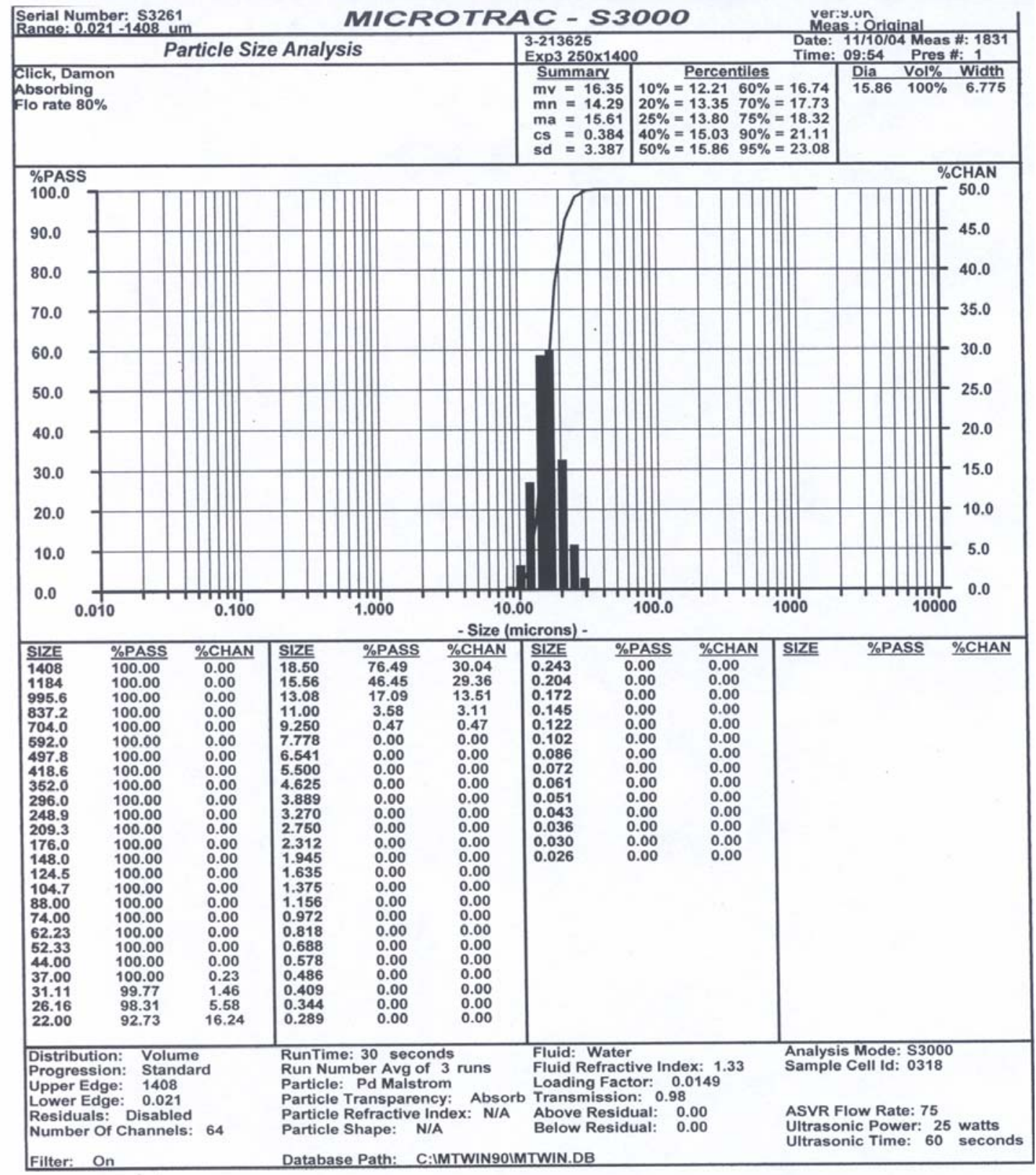


WSRC-TR-2005-00077

Revision 0

Figure D.6 Microtrac analysis of solids collected on the 11-12 micron sieve (250x1400) from Exp 2 which was done with DI $\mathrm{H}_{2} \mathrm{O}$. Data is on a volume basis.

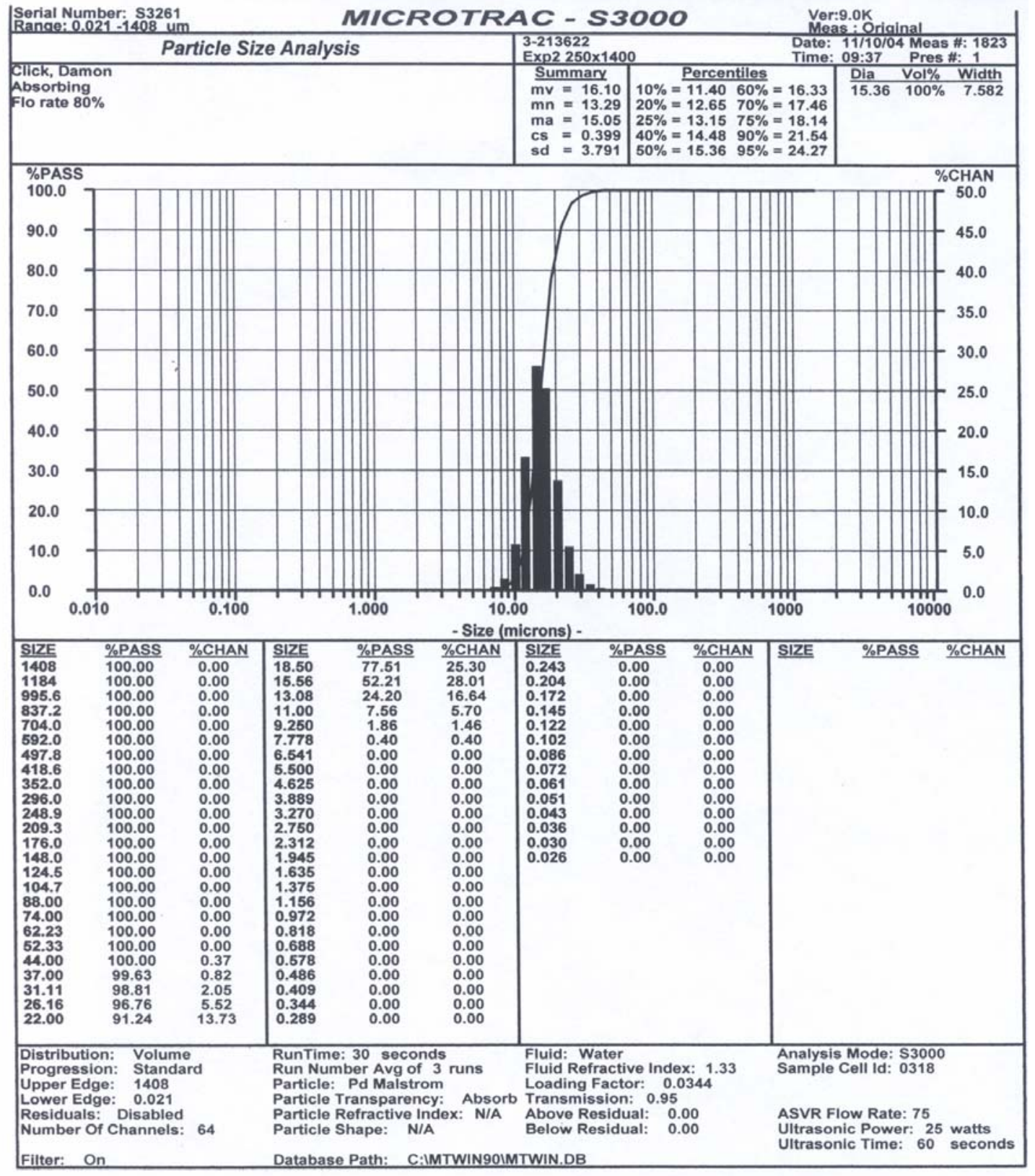


WSRC-TR-2005-00077

Revision 0

Figure D.7 Microtrac analysis of solids collected on the 12-14 micron sieve (200x1400 mesh) from Exp 3 which was done with DI $\mathrm{H}_{2} \mathrm{O}$. Data is on a volume basis.

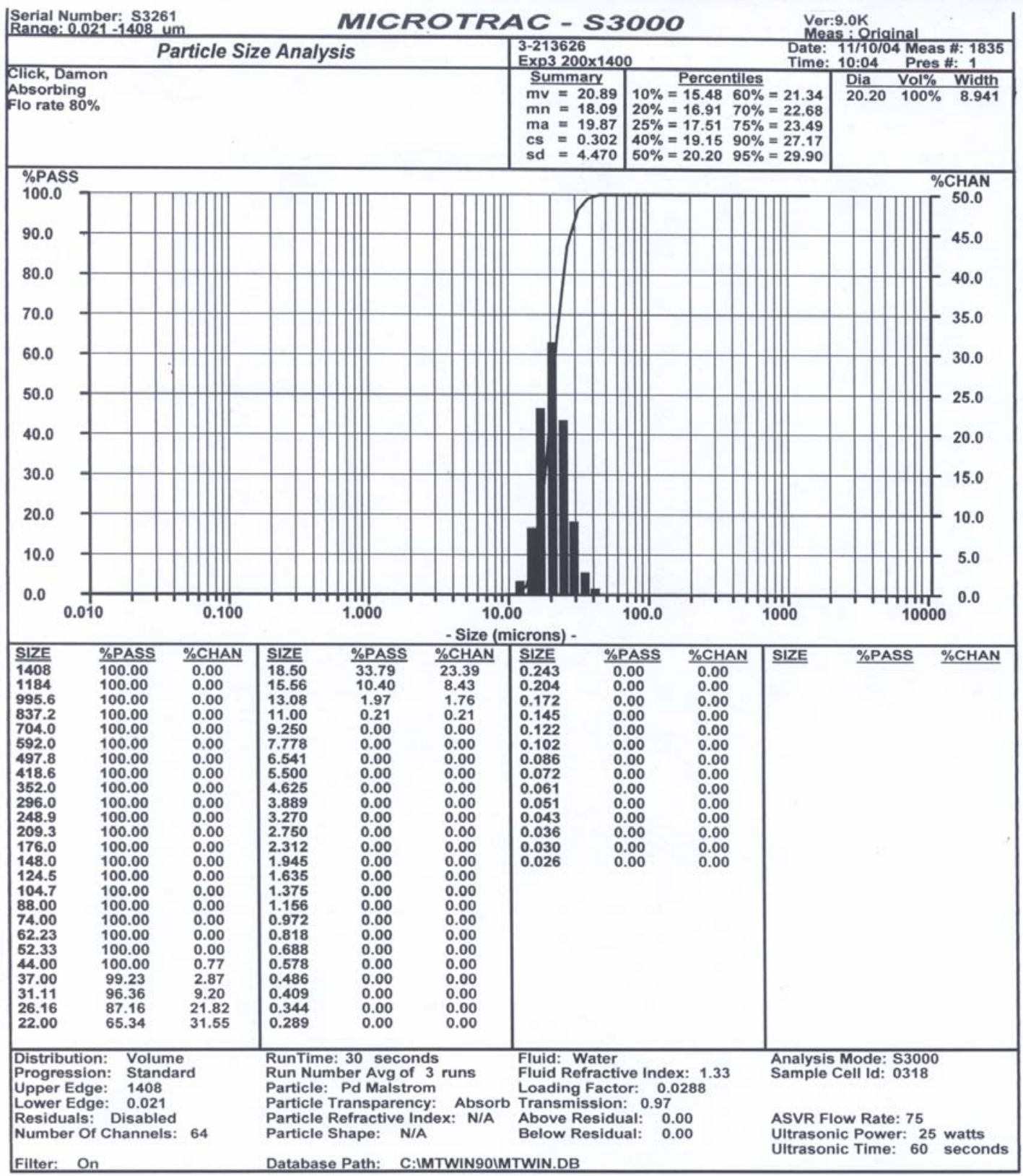


WSRC-TR-2005-00077

Revision 0

Figure D.8 Microtrac analysis of solids collected on the 12-14 micron sieve (200x1400) from Exp 2 which was done with $\mathrm{DI} \mathrm{H}_{2} \mathrm{O}$. Data is on a volume basis.

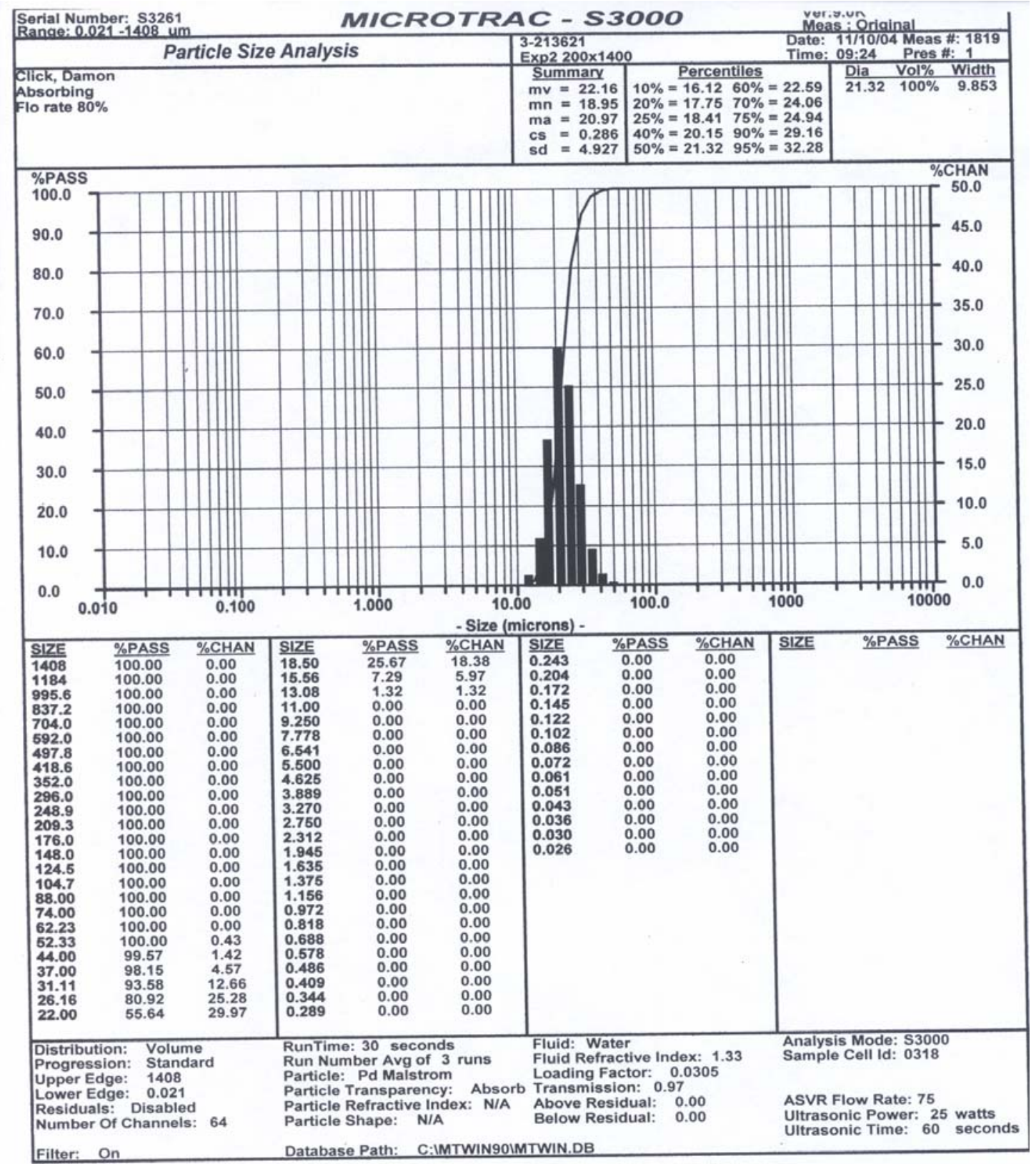

